Sun, Z., Jian, Z., Stock, J.M., Larsen, H.C., Klaus, A., Alvarez Zarikian, C.A., and the Expedition $367 / 368$ Scientists

Proceedings of the International Ocean Discovery Program Volume 367/368

publications.iodp.org
https://doi.org/10.14379/iodp.proc.368X.103.2020

Check for updates

\section{Return to Site U1503 ${ }^{1}$}

L.B. Childress, C.A. Alvarez Zarikian, A. Briais, K.A. Dadd, J.-M. Deng, T.W. Höfig, X.-L. Huang, B. Li, J. Lin, C. Liu, Z. Liu, M.F.R. Nirrengarten, D.W. Peate, N. Qiu, S. Satolli, J.M. Stock, Z. Sun, F.M. van der Zwan, R. Xiang, L. Yi, and L. Zhong $^{2}$

Keywords: International Ocean Discovery Program, IODP, JOIDES Resolution, Expedition 367, Expedition 368, Expedition 368X, South China Sea Rifted Margin, Site U1503, northern South China Sea, rifted margin, continent-ocean transition zone, hyperextension, continental breakup, lithosphere thinning, outer margin high, embryonic ocean

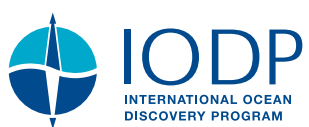

\section{Contents}

1 Background and objectives

4 Operations

8 Lithostratigraphy

15 Igneous petrology and structural geology

20 Biostratigraphy

21 Paleomagnetism

27 Geochemistry

29 Physical properties

33 Downhole measurements and seismic correlation

37 References

\section{Background and objectives}

International Ocean Discovery Program (IODP) Site U1503 is located at 3867.7 meters below sea level (mbsl) (Figures F1, F2) near the top of the basement high named Ridge $C$. Ridge $C$ is the most seaward ridge of the three margin-parallel ridges $(\mathrm{A}, \mathrm{B}$, and $\mathrm{C})$ that characterize the lower continental slope underlain by thin $(5-7 \mathrm{~km})$ crust (Figures F3, F4). Ridge $\mathrm{C}$ is believed to represent at least partial if not full igneous crust and hence the crustal structure after the completion of continental breakup along this margin segment of the northern South China Sea (SCS).

Ridge $\mathrm{C}$ is a $50 \mathrm{~km}$ long continuous basement ridge that consists of two ridges separated by seaward-dipping normal faults (Figures F4, F5, F6). The offset of the normal faults is as much as $\sim 400 \mathrm{~ms}$ two-way traveltime (TWT; $400-600 \mathrm{~m}$ ), and faulting was apparently active shortly after formation of igneous crust. Only the oldest of the overlying sediments that fill the half-graben basins seems to be offset by the faults, whereas the younger sediments filling in the majority of the accommodation space generated by normal faulting show a draping (and compaction) structure over the tectonically generated basement relief. Ridge $C$ is very linear and is parallel to Ridge B (see the Site U1500 chapter [Stock et al., 2018]) and to seafloor spreading anomalies south of the ridge (Figure F2).

One important objective at Site U1503 was to sample the lowermost $\sim 300$ m of sediments on top of the basement to constrain the age and subsidence history of the crust at this location, the timing of normal faulting, and the environment of the early half-graben fill. The most important goal was to sample the igneous stratigraphy to at least $100 \mathrm{~m}$ in the underlying basement.

Based on the breakup-related or ocean-spreading basaltic magmatism found at Sites U1502 (Ridge A) and U1500 (Ridge B) (see
Figure F1. Bathymetry and seismic lines, Site U1503.

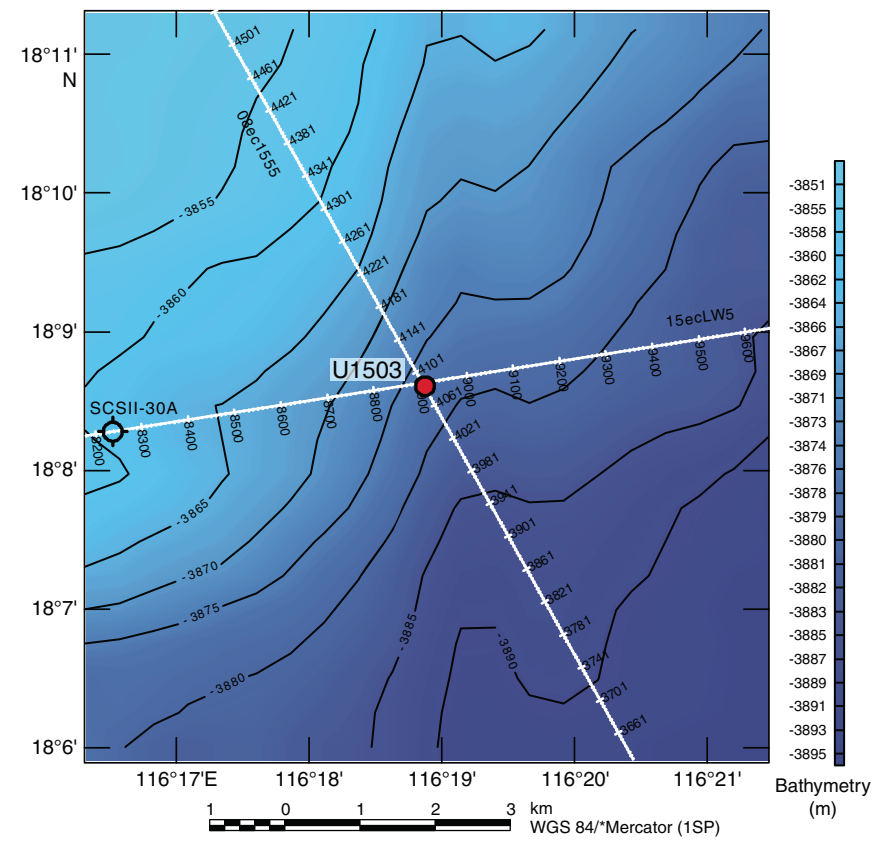

the Site U1500 chapter and the Site U1502 chapter [Stock et al., 2018; Larsen et al., 2018a), we believe that this rifted margin, unlike magma-starved Iberia-type margins, experienced significant igneous activity during breakup and that extended continental lithosphere within the continent-ocean transition (COT), if present at all, is now likely to be more or less covered by igneous rocks. By im-

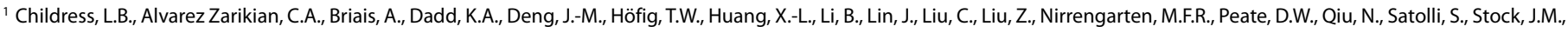
Sun, Z., van der Zwan, F.M., Xiang, R., Yi, L., and Zhong, L., 2020. Return to Site U1503. In Sun, Z., Jian, Z., Stock, J.M., Larsen, H.C., Klaus, A., Alvarez Zarikian, C.A., and the Expedition 367/368 Scientists, South China Sea Rifted Margin. Proceedings of the International Ocean Discovery Program, 367/368: College Station, TX (International Ocean Discovery Program). https://doi.org/10.14379/iodp.proc.368X.103.2020

2 Expedition 367/368 Scientists' affiliations.

MS 368X-103: Published 23 April 2020

This work is distributed under the Creative Commons Attribution 4.0 International (CC BY 4.0) license. (cc))BY 
Figure F2. Bathymetric maps with Expedition 367/368 sites (stars) and (A) regional and (B) local coverage of multichannel seismic reflection and ocean-bottom seismometer data. Thick blue and red lines are key seismic lines used for drilling transect planning. A. Magnetic isochrons (pink lines) from Briais et al. (1993). B. Magnetic picks (pink squares) from the same reference, extracted from the Seton et al. (2014) compilation. Chron labels for the picks correspond to the old edge of the normal polarity intervals (see Ogg et al. [2016] timescale for ages). Orange square = ODP Leg 184 Site 1148, yellow squares $=$ IODP Expedition 349 Sites U1432 and U1435.

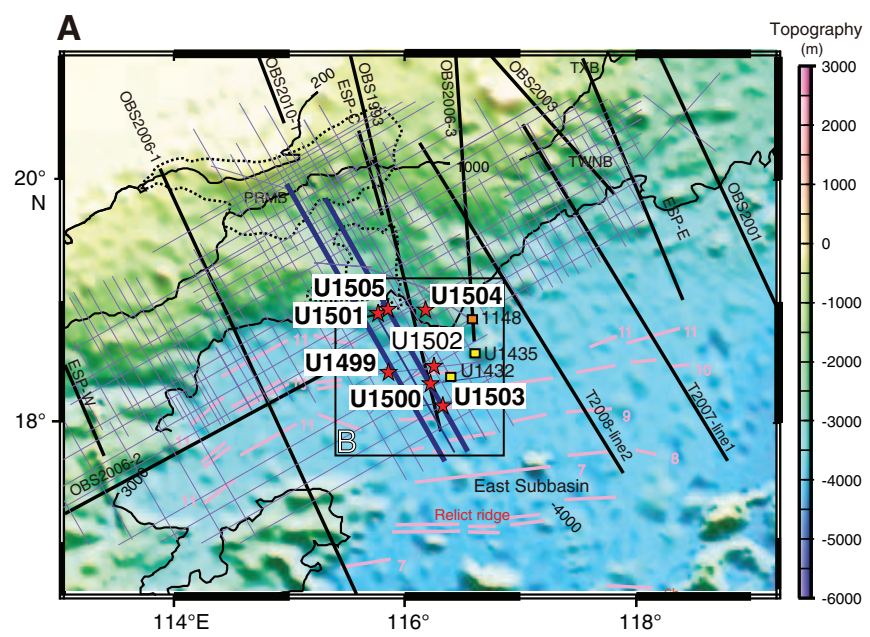

B

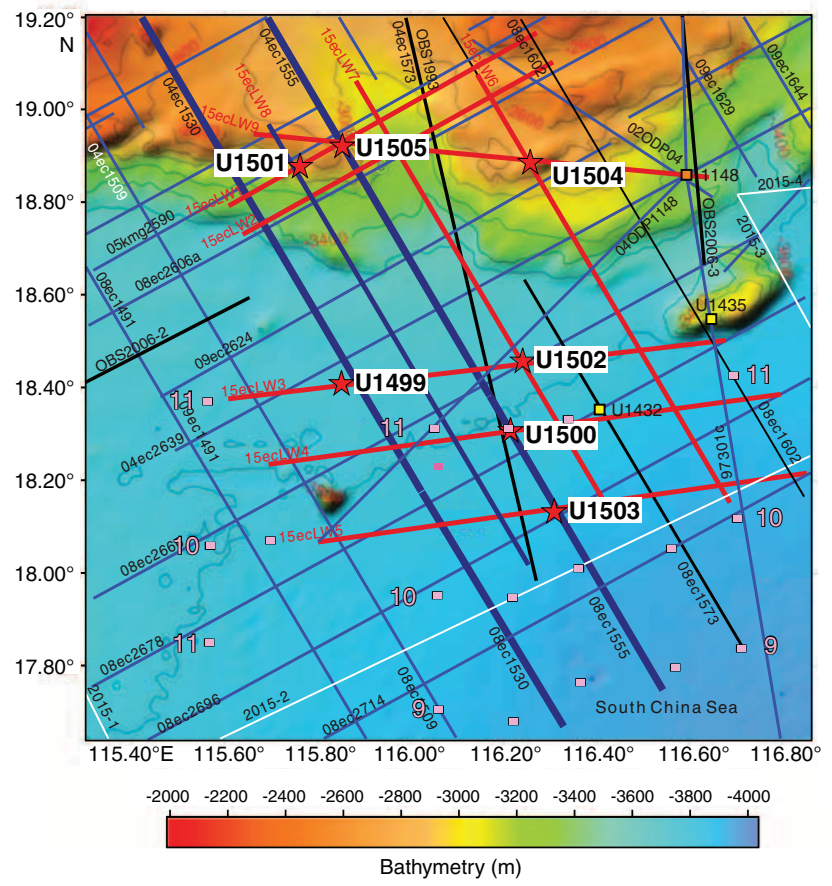

plication, the reading of the terminal stages of lithospheric thinning prior to final breakup needs to be gleaned from the detailed composition of the igneous products, such as continental crustal contamination of the magmas, depth and shallowing of mantle melting with time, and mantle source composition including wetness and possible thermal anomalies. The crust at Ridge $\mathrm{C}$ is interpreted to represent the oceanic end-member of the transition from breakup magmatism initially modified by an overlying lid of continental lithosphere to accretion of igneous crust unmodified by a preexisting lithosphere. Deep representative sampling of the basaltic rocks at this site therefore forms an important reference frame for the mod-
Figure F3. Two-way traveltime to (A) basement ( $\mathrm{Tg}$ reflector) and (B) T60 unconformity. Proposed drilling transect (thick black line) is approximately at the center of a margin segment bounded to the southwest by a transform fault. Northeastern boundary of margin segment is around IODP Expedition 349 Site U1435. At this location, outer margin high (OMH) and Ridge A seem to coalesce, and Ridges $B$ and $C$ of the COT become indistinct toward the northeast within the next margin segment. Note that the $\mathrm{OMH}$ is slightly oblique to the more parallel Ridges $A, B$, and $C$.
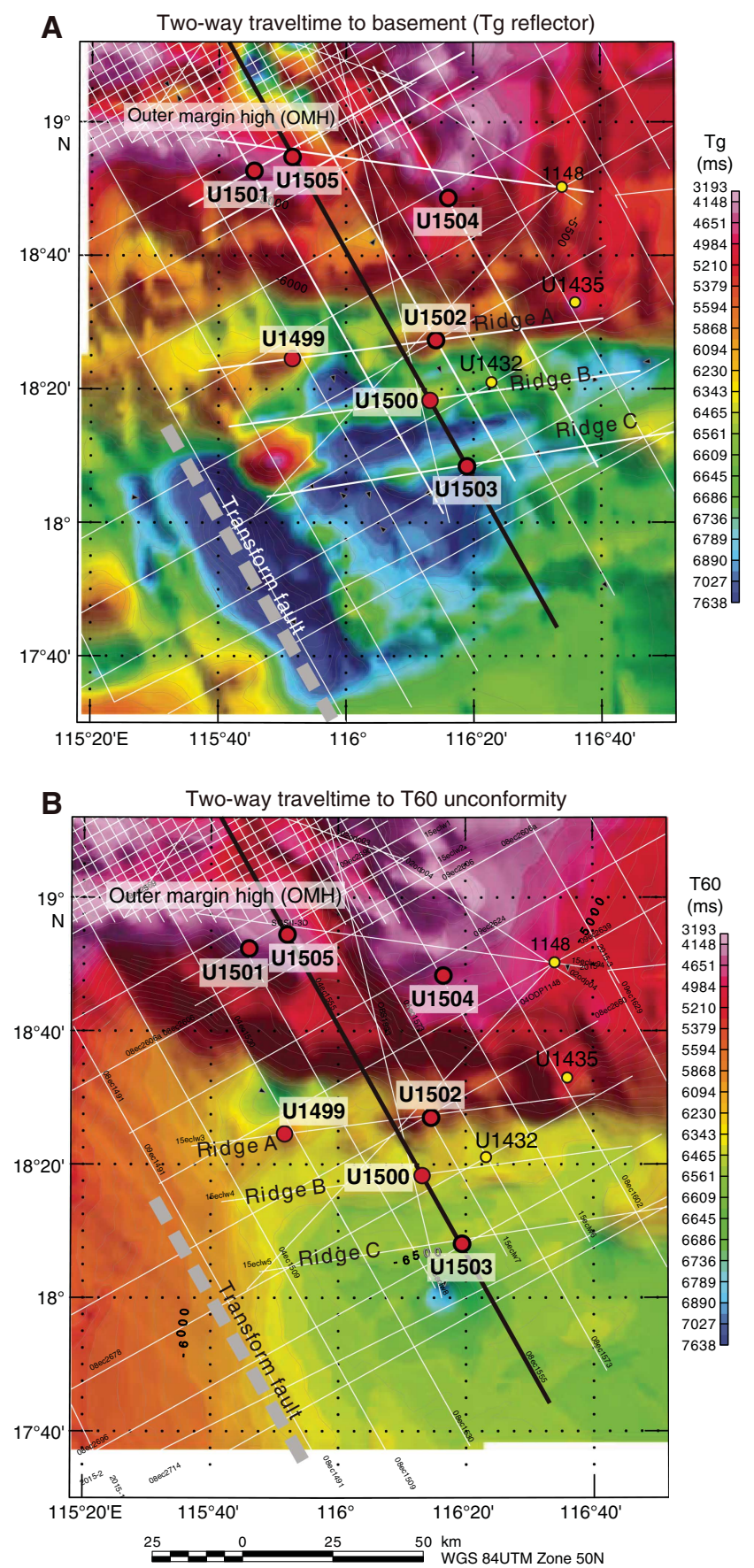

eling of breakup, and basement penetration must be sufficient to provide a representative sampling of igneous units.

With an estimated $1640 \mathrm{~m}$ of sediment overlying the basement target, Site U1503 was a challenging operation. During Expedition 368 , following installation of $991.5 \mathrm{~m}$ of steel casing in the upper sediments, repeated breakdown of the drawworks' low clutch dia- 
Figure F4. Deep crustal time-migrated seismic reflection data without and with interpretation. Note the rather thin lower crust (two layers) above a strong Mohorovičić seismic discontinuity (Moho) reflector that can be followed oceanward. Moho reflection is weak to absent seaward from around the interpreted COT. Wide-angle seismic data (Yan et al., 2001) confirm 6 km thick ocean crust (OC) seaward of the COT. A large detachment fault 150 km inland of the COT separates more stable crust landward from that of highly extended crust seaward. An OMH is a fairly consistent feature along this margin segment. Key seismic unconformities are shown in purple (T70; 32 Ma breakup unconformity?) and blue (T60; 23 Ma regional basin event). These ages are inferred from longdistance (>100 km) correlation of seismic unconformities with industry holes and ODP Leg 184 Site 1148 (T60); ages need confirmation by coring and are only tentative. Tg (black) is basement. Arrows = approximate positions of seafloor magnetic anomalies with chron numbers (from Briais et al., 1993). Seismic data are from Line 04ec1555-08ec1555 (courtesy of Chinese National Offshore Oil Corporation [CNOOC]). Location of line is shown in Figure F3. CDP = common depth point. $\mathrm{C} 11 \mathrm{n}, \mathrm{C} 10 \mathrm{n}$, and $\mathrm{C} 9 \mathrm{n}=$ approximate location of normal polarity magnetic isochrons. $\mathrm{MSB}=$ midslope basin. $\mathrm{P}=$ projected.
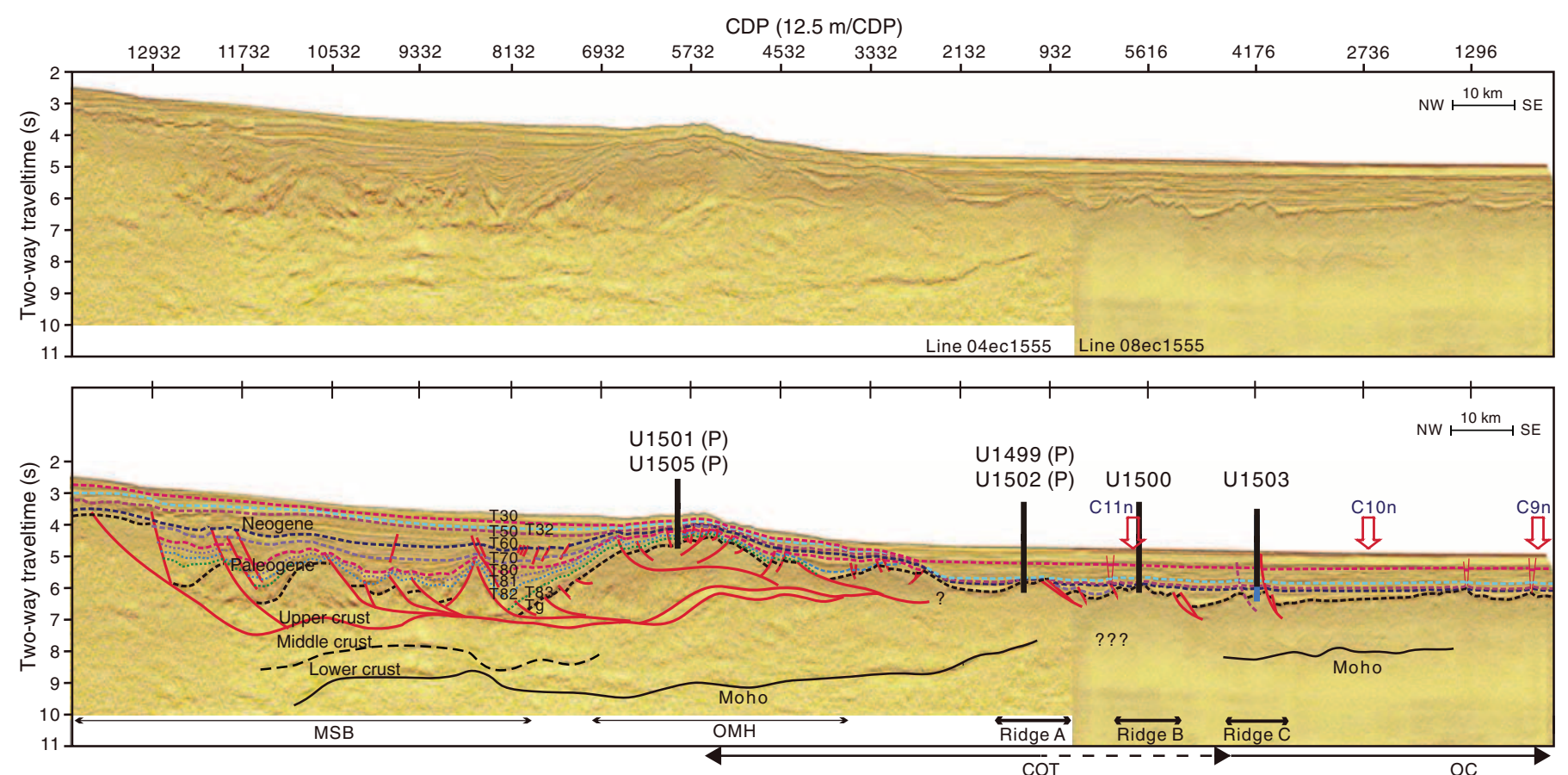

Figure F5. Seismic Line 08ec1555, which is the primary seismic line for Site U1503, and crossing seismic line for proposed Site SCSII-30A. Dashed lines = unconformities, red solid lines $=$ faults.
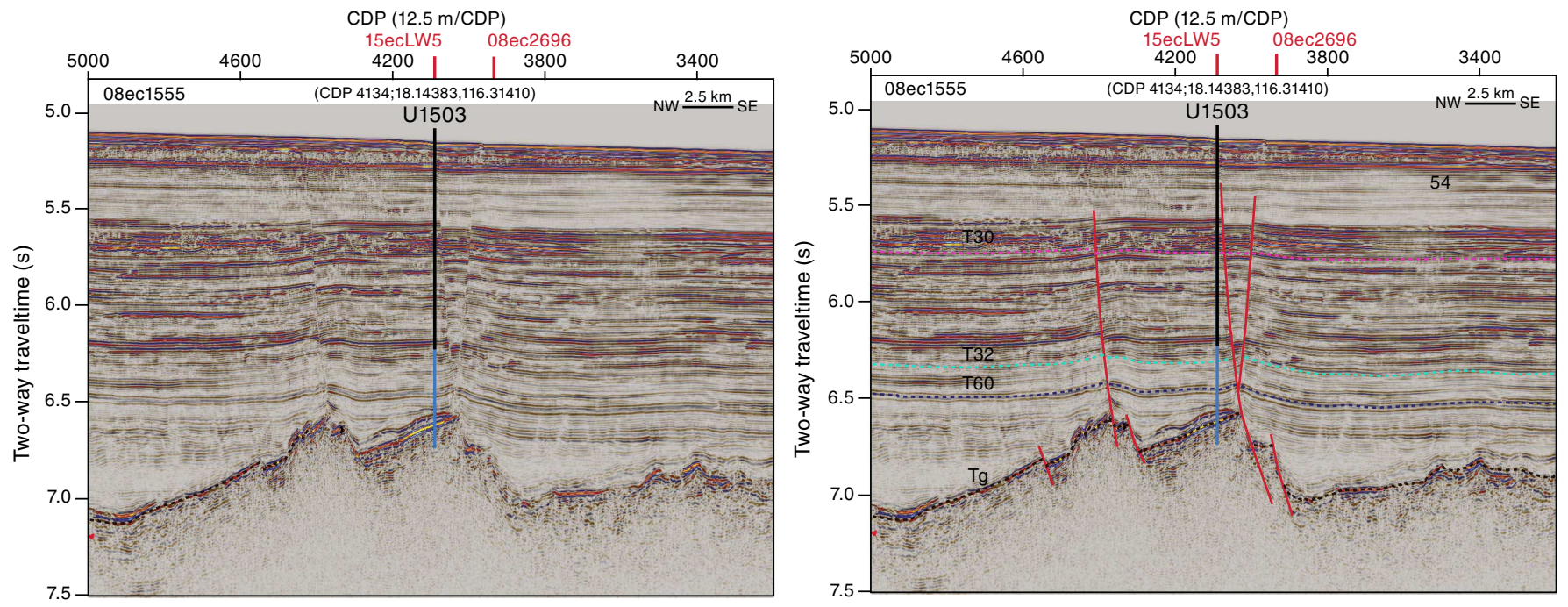
Figure F6. Crossing seismic Line 15ecLW5 for Site U1503. Dashed lines = unconformities.

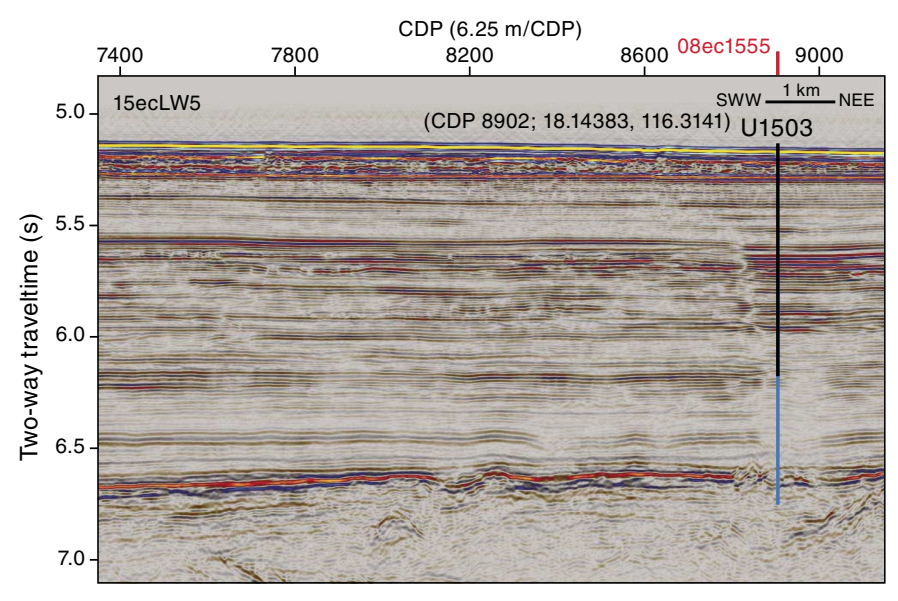

phragm prevented completion of Expedition 368 operations, and Site U1503 was left for possible occupation during a future expedition. Despite this setback to Expedition 368 and the South China Sea Rifted Margin program, Hole U1503A was completed during Expedition 368X, including sampling the lowermost $\sim 300 \mathrm{~m}$ of sediment above the basement and more than $100 \mathrm{~m}$ of igneous stratigraphy within the basement.

\section{Operations}

We conducted operations in one hole at Site U1503 with the primary objective of sampling and logging the lowermost sediments and $100 \mathrm{~m}$ into the underlying basement. We successfully penetrated from $995.10 \mathrm{~m}$ below the seafloor (below bottom of casing) to the sediment/basalt contact at $1597.84 \mathrm{~m}$ and $112.26 \mathrm{~m}$ into the underlying basalts. Core recovery in the sedimentary section was highly variable and generally poor (21\%). In the basalts, core recovery was variable but relatively high for hard rock coring (43\%).

Hole U1503A is located at $18^{\circ} 08.6300^{\prime} \mathrm{N}, 116^{\circ} 18.8456^{\prime} \mathrm{E}$ in a water depth of $3867.7 \mathrm{~m}$. To achieve the deep objectives of this site, a reentry system and $991.5 \mathrm{~m}$ of $103 / 4$ inch casing was installed during Expedition 368 (see the Site U1503 chapter [Larsen et al., 2018b]). We conducted the following operations in Hole U1503A (Table T1):

- Added a secondary free-fall funnel (FFF) with 2.7 m extension into the reentry system previously installed in Hole U1503A,

- Cored the sediment sequence with the rotary core barrel (RCB) system from 991.5 to $1597.84 \mathrm{~m}$ (602.74 $\mathrm{m}$ cored; recovery = $128.01 \mathrm{~m} ; 21 \%)$,

- Cored $112.26 \mathrm{~m}$ into the underlying basalt with the RCB system $(1597.84-1710.10 \mathrm{mbsf}$; recovery $=47.91 \mathrm{~m} ; 43 \%)$, and

- Logged with the Versatile Seismic Imager (VSI) tool within the casing.

A diagram of the secondary reentry cone and casing in Hole U1503A is shown in Figure F7.

\section{Hong Kong port call}

Expedition $368 \mathrm{X}$ began at $0800 \mathrm{~h}$ (all times are ship local time [same as Hong Kong]; UTC +8 h) on 15 November 2018 at the China Merchants Wharf in Hong Kong. The IODP JOIDES Resolution Science Operator (JRSO) technical staff (14 additional), Expedition Project Manager (EPM), and seven of nine scientists boarded

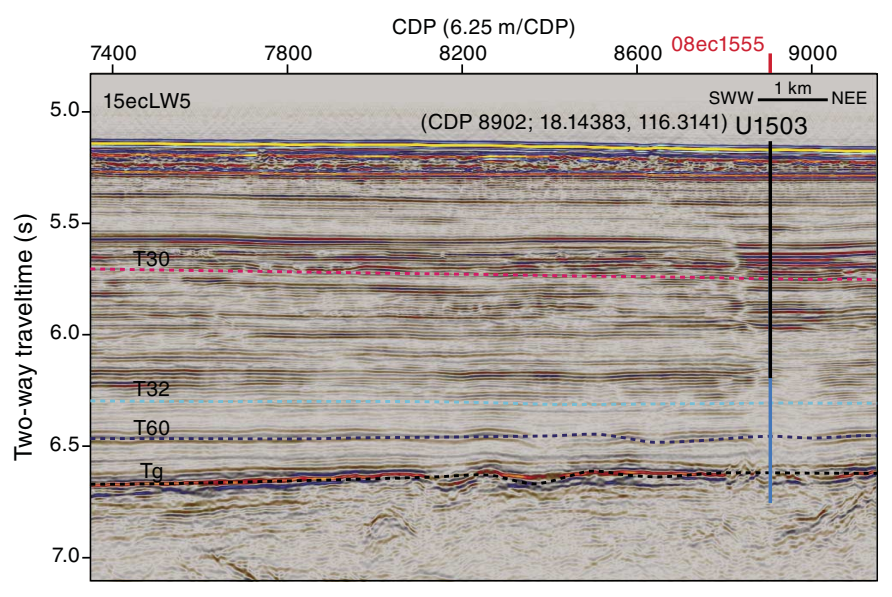

the vessel on 15 November. The remainder of the science party boarded on 16 November. The scientists began expedition preparations, which included introductions and an orientation to shipboard computing resources.

On the first day of the port call, we loaded hazardous freight, 155 short tons of potable water, and 404 short tons of drill water, all of which were loaded from a barge on the starboard side of the vessel. On the second day of the port call, 71.9 metric tons of marine gas oil were pumped on board from a barge on the starboard side. The Schlumberger mechanic repaired the Schlumberger active heave wireline compensator hydraulic system with parts that were air freighted to the port call. The system was tested in port after the repairs were completed.

During the two-day port call, a reentry funnel extension was prepared to extend the reentry system in Hole U1503A. Additionally, the outer core barrel was prepared and the RCB core barrels were spaced out. The coring assembly was laid out on the piperacker skate track, ready for a quick deployment on arrival at the site. The passage plan for our expedition was completed, and arrangements were made with the agent and immigration for a departure at $0800 \mathrm{~h}$ on 17 November. All port call-generated trash was offloaded to the pier, the pier was cleaned, and all equipment was secured for sailing. During the second day of port call, the science party continued expedition preparations, which included an orientation to life at sea, general safety introductions and tours, and introductions to the laboratories. The EPM gave a presentation about expedition expectations, tasks, and reports. The science party also received shipboard safety introductions by the Captain, First Mate, and Physician.

At $0500 \mathrm{~h}$ on 17 November, immigration personnel arrived on board and cleared the personnel and vessel for departure. Shortly before $0800 \mathrm{~h}$, the pilot arrived on board. With assistance from two harbor tugs, Hai Tong and Hai Hoi, the vessel was underway, and the last line was released at $0824 \mathrm{~h}$. The vessel proceeded to the pilot station, and the pilot departed the vessel at $0854 \mathrm{~h}$. While underway, the science party continued training in the laboratories, which included introductions to the handheld portable X-ray fluorescence (pXRF) spectrometer, curation, and description software. The science party also received a lifeboat safety orientation and tours of the bridge and dynamic positioning system. The transit was completed after $24.6 \mathrm{~h}$ and ended at the expedition's first and only site, U1503. The average vessel speed was $11.5 \mathrm{kt}$ over $284 \mathrm{nmi}$. The vessel 
Table T1. Core summary, Site U1503. DRF = drilling depth below rig floor, DSF = drilling depth below seafloor. Core type: $\mathrm{R}=$ rotary core barrel. (Continued on next page.) Download table in CSV format.

\begin{tabular}{|c|c|c|c|c|c|c|c|c|c|c|c|}
\hline \multicolumn{12}{|c|}{ Hole U1503A } \\
\hline \multicolumn{6}{|c|}{ Latitude: } & \multicolumn{6}{|c|}{$18^{\circ} 08.6300^{\prime} \mathrm{N}$} \\
\hline \multicolumn{6}{|c|}{ Longitude: } & \multicolumn{6}{|c|}{$116^{\circ} 18.8456^{\prime} \mathrm{E}$} \\
\hline \multicolumn{6}{|c|}{ Time on hole (days): } & \multirow{2}{*}{\multicolumn{2}{|c|}{$\begin{array}{l}18.5 \\
16.49\end{array}$}} & & & & \\
\hline \multicolumn{6}{|c|}{ Time on hole drilling and coring (d): } & & & & & & \\
\hline \multicolumn{6}{|c|}{ Time on hole logging and downhole (d): } & 0.75 & & & & & \\
\hline Seaf & loor $(\mathrm{d}$ & ill pipe me & surement bel & low rig floor, & m DRF): & 3879.0 & & & & & \\
\hline Dist & ance be & tween rig & oor and sea le & evel (m): & & 11.3 & & & & & \\
\hline Wat & er dept & h (drill pipe & measuremen & it from sea le & vel, m DSF): & 3867.7 & & & & & \\
\hline Tota & I penet & ration (drill & depth below & seafloor, $\mathrm{m} \mathrm{D}$ & SF): & 1710.1 & & & & & \\
\hline Tota & I depth & (drill pipe & heasurement & from rig floo & $r, m$ DRF): & 5589.1 & & & & & \\
\hline Tota & I length & of cored s & ction (m): & & & 715.0 & & & & & \\
\hline Tota & I core $\mathrm{r}$ & ecovered $(r$ & & & & 175.7 & & & & & \\
\hline Core & recove & ry (\%): & & & & 26 & & & & & \\
\hline Drill & ed inte & val (m): & & & & 0.0 & & & & & \\
\hline Tota & I numb & er of cores: & & & & 87.0 & & & & & \\
\hline Core & Type & $\begin{array}{l}\text { Top of } \\
\text { interval } \\
\text { DSF (m) }\end{array}$ & $\begin{array}{l}\text { Bottom of } \\
\text { interval } \\
\text { DSF (m) }\end{array}$ & $\begin{array}{l}\text { Interval } \\
\text { advanced } \\
\text { (m) }\end{array}$ & $\begin{array}{c}\text { Core } \\
\text { recovered } \\
\text { length }(\mathrm{m})\end{array}$ & $\begin{array}{l}\text { Core } \\
\text { curated } \\
(\mathrm{m})\end{array}$ & $\begin{array}{c}\text { Recovery } \\
(\%)\end{array}$ & $\begin{array}{l}\text { Time on } \\
\text { deck UTC } \\
\text { (h) }\end{array}$ & $\begin{array}{l}\text { Time on deck } \\
\text { (ship local time; } \\
\text { UTC }+8 \mathrm{~h} \text { ) }\end{array}$ & $\begin{array}{l}\text { Time to cut } \\
\text { core (min) }\end{array}$ & $\begin{array}{c}\text { Mud } \\
\text { pumped } \\
\text { (bbl) }\end{array}$ \\
\hline $368 X-1$ & J1503A & & & & & & & & & & \\
\hline 2 & $\mathrm{R}$ & 995.1 & 1000.8 & 5.7 & 1.88 & 1.88 & 33 & 19 Nov 20181150 & 19 Nov 20181950 & 25 & 30 \\
\hline 3 & $\mathrm{R}$ & 1000.8 & 1010.2 & 9.4 & 0.33 & 0.33 & 4 & 19 Nov 20181410 & 19 Nov 20182210 & 15 & \\
\hline 4 & $\mathrm{R}$ & 1010.2 & 1019.8 & 9.6 & 1.24 & 1.24 & 13 & 19 Nov 20181620 & 20 Nov 20180020 & 25 & \\
\hline 5 & $\mathrm{R}$ & 1019.8 & 1029.4 & 9.6 & 8.22 & 8.22 & 86 & 19 Nov 20181910 & 20 Nov 20180310 & 60 & 30 \\
\hline 6 & $\mathrm{R}$ & 1029.4 & 1038.9 & 9.5 & 3.34 & 3.34 & 35 & 19 Nov 20182125 & 20 Nov 20180525 & 45 & \\
\hline 7 & $\mathrm{R}$ & 1038.9 & 1048.4 & 9.5 & 0.00 & 0.00 & 0 & 19 Nov 20182345 & 20 Nov 20180745 & 15 & \\
\hline 8 & $\mathrm{R}$ & 1048.4 & 1058.0 & 9.6 & 3.34 & 3.34 & 35 & 20 Nov 20180200 & 20 Nov 20181000 & 35 & 20 \\
\hline 9 & $\mathrm{R}$ & 1058.0 & 1067.6 & 9.6 & 4.31 & 4.31 & 45 & 20 Nov 20180420 & 20 Nov 20181220 & 40 & \\
\hline 10 & $\mathrm{R}$ & 1067.6 & 1077.2 & 9.6 & 0.51 & 0.51 & 5 & 20 Nov 20180630 & 20 Nov 20181430 & 20 & \\
\hline 11 & $\mathrm{R}$ & 1077.2 & 1086.8 & 9.6 & 0.31 & 0.31 & 3 & 20 Nov 20180830 & 20 Nov 20181630 & 10 & 20 \\
\hline 12 & $\mathrm{R}$ & 1086.8 & 1096.4 & 9.6 & 2.70 & 2.70 & 28 & 20 Nov 20181040 & 20 Nov 20181840 & 25 & \\
\hline 13 & $\mathrm{R}$ & 1096.4 & 1106.0 & 9.6 & 1.19 & 1.19 & 12 & 20 Nov 20181250 & 20 Nov 20182050 & 20 & \\
\hline 14 & $\mathrm{R}$ & 1106.0 & 1115.6 & 9.6 & 0.00 & 0.00 & 0 & 20 Nov 20181445 & 20 Nov 20182245 & 10 & 30 \\
\hline 15 & $\mathrm{R}$ & 1115.6 & 1125.1 & 9.5 & 0.84 & 0.84 & 9 & 20 Nov 20181650 & 21 Nov 20180050 & 10 & \\
\hline 16 & $\mathrm{R}$ & 1125.1 & 1134.7 & 9.6 & 4.69 & 4.69 & 49 & 20 Nov 20181910 & 21 Nov 20180310 & 40 & \\
\hline 17 & $\mathrm{R}$ & 1134.7 & 1144.3 & 9.6 & 3.39 & 3.39 & 35 & 20 Nov 20182120 & 21 Nov 20180520 & 30 & 30 \\
\hline 18 & $\mathrm{R}$ & 1144.3 & 1153.9 & 9.6 & 0.00 & & 0 & 20 Nov 20182315 & 21 Nov 20180715 & 10 & \\
\hline 19 & $\mathrm{R}$ & 1153.9 & 1163.5 & 9.6 & 0.00 & 0.00 & 0 & 21 Nov 20180110 & 21 Nov 20180910 & 10 & \\
\hline 20 & $\mathrm{R}$ & 1163.5 & 1173.1 & 9.6 & 0.24 & 0.24 & 3 & 21 Nov 20180305 & 21 Nov 20181105 & 15 & 30 \\
\hline 21 & $\mathrm{R}$ & 1173.1 & 1182.7 & 9.6 & 1.05 & 1.05 & 11 & 21 Nov 20180500 & 21 Nov 20181300 & 10 & \\
\hline 22 & $\mathrm{R}$ & 1182.7 & 1192.2 & 9.5 & 1.00 & 1.00 & 11 & 21 Nov 20180710 & 21 Nov 20181510 & 15 & \\
\hline 23 & $\mathrm{R}$ & 1192.2 & 1201.8 & 9.6 & 2.70 & 2.70 & 28 & 21 Nov 20180955 & 21 Nov 20181755 & 25 & 30 \\
\hline 24 & $\mathrm{R}$ & 1201.8 & 1211.4 & 9.6 & 1.95 & 1.95 & 20 & 21 Nov 20181230 & 21 Nov 20182030 & 20 & 30 \\
\hline 25 & $\mathrm{R}$ & 1211.4 & 1221.0 & 9.6 & 0.38 & 0.38 & 4 & 21 Nov 20181425 & 21 Nov 20182225 & 10 & \\
\hline 26 & $\mathrm{R}$ & 1221.0 & 1230.6 & 9.6 & 1.29 & 1.29 & 13 & 21 Nov 20181650 & 22 Nov 20180050 & 20 & \\
\hline 27 & $\mathrm{R}$ & 1230.6 & 1240.1 & 9.5 & 1.05 & 1.05 & 11 & 21 Nov 20181855 & 22 Nov 20180255 & 15 & \\
\hline 28 & $\mathrm{R}$ & 1240.1 & 1249.7 & 9.6 & 2.76 & 2.76 & 29 & 21 Nov 20182055 & 22 Nov 20180455 & 30 & 30 \\
\hline 29 & $\mathrm{R}$ & 1249.7 & 1259.3 & 9.6 & 0.00 & 0.00 & 0 & 21 Nov 20182255 & 22 Nov 20180655 & 15 & \\
\hline 30 & $\mathrm{R}$ & 1259.3 & 1268.9 & 9.6 & 1.08 & 1.08 & 11 & 22 Nov 20180100 & 22 Nov 20180900 & 15 & \\
\hline 31 & $\mathrm{R}$ & 1268.9 & 1278.5 & 9.6 & 3.10 & 3.10 & 32 & 22 Nov 20180330 & 22 Nov 20181130 & 40 & 30 \\
\hline 32 & $\mathrm{R}$ & 1278.5 & 1288.1 & 9.6 & 0.07 & 0.07 & 1 & 22 Nov 20180530 & 22 Nov 20181330 & 10 & \\
\hline 33 & $\mathrm{R}$ & 1288.1 & 1297.6 & 9.5 & 0.04 & 0.04 & 0 & 22 Nov 20180740 & 22 Nov 20181540 & 10 & \\
\hline 34 & $\mathrm{R}$ & 1297.6 & 1307.2 & 9.6 & 0.09 & 0.09 & 1 & 22 Nov 20180955 & 22 Nov 20181755 & 10 & 30 \\
\hline 35 & $\mathrm{R}$ & 1307.2 & 1316.9 & 9.7 & 0.58 & 0.58 & 6 & 22 Nov 20181215 & 22 Nov 20182015 & 20 & \\
\hline 36 & $\mathrm{R}$ & 1316.9 & 1326.5 & 9.6 & 0.33 & 0.33 & 3 & 22 Nov 20181425 & 22 Nov 20182225 & 15 & \\
\hline 37 & $\mathrm{R}$ & 1326.5 & 1336.1 & 9.6 & 0.11 & 0.11 & 1 & 22 Nov 20181635 & 23 Nov 20180035 & 15 & 30 \\
\hline 38 & $\mathrm{R}$ & 1336.1 & 1345.7 & 9.6 & 0.00 & 0.00 & 0 & 22 Nov 20181830 & 23 Nov 20180230 & 15 & \\
\hline 39 & $\mathrm{R}$ & 1345.7 & 1355.3 & 9.6 & 0.11 & 0.11 & 1 & 22 Nov 20182030 & 23 Nov 20180430 & 10 & \\
\hline 40 & $\mathrm{R}$ & 1355.3 & 1364.9 & 9.6 & 5.88 & 5.88 & 61 & 22 Nov 20182345 & 23 Nov 20180745 & 90 & 30 \\
\hline 41 & $\mathrm{R}$ & 1364.9 & 1374.5 & 9.6 & 6.97 & 6.97 & 73 & 23 Nov 20180305 & 23 Nov 20181105 & 90 & \\
\hline 42 & $\mathrm{R}$ & 1374.5 & 1384.1 & 9.6 & 1.90 & 1.90 & 20 & 23 Nov 20180525 & 23 Nov 20181325 & 30 & \\
\hline 43 & $\mathrm{R}$ & 1384.1 & 1393.7 & 9.6 & 2.47 & 2.47 & 26 & 23 Nov 20180810 & 23 Nov 20181610 & 50 & 30 \\
\hline 44 & $\mathrm{R}$ & 1393.7 & 1403.3 & 9.6 & 0.12 & 0.12 & 1 & 23 Nov 20181020 & 23 Nov 20181820 & 15 & \\
\hline 45 & $\mathrm{R}$ & 1403.3 & 1412.9 & 9.6 & 2.08 & 2.08 & 22 & 23 Nov 20181315 & 23 Nov 20182115 & 60 & \\
\hline 46 & $\mathrm{R}$ & 1412.9 & 1422.5 & 9.6 & 3.07 & 3.07 & 32 & 23 Nov 20181705 & 24 Nov 20180105 & 120 & 30 \\
\hline 47 & $\mathrm{R}$ & 1422.5 & 1432.1 & 9.6 & 5.05 & 5.05 & 53 & 23 Nov 20182100 & 24 Nov 20180500 & 125 & \\
\hline 48 & $\mathrm{R}$ & 1432.1 & 1441.7 & 9.6 & 3.15 & 3.15 & 33 & 24 Nov 20180125 & 24 Nov 20180925 & 160 & \\
\hline 49 & $\mathrm{R}$ & 1441.7 & 1451.3 & 9.6 & 4.50 & 4.50 & 47 & 24 Nov 20180640 & 24 Nov 20181440 & 205 & 30 \\
\hline 50 & $\mathrm{R}$ & 1451.3 & 1460.9 & 9.6 & 5.59 & 5.59 & 58 & 24 Nov 20181055 & 24 Nov 20181855 & 150 & \\
\hline
\end{tabular}


Table T1 (continued).

\begin{tabular}{|c|c|c|c|c|c|c|c|c|c|c|c|}
\hline Core & Type & $\begin{array}{l}\text { Top of } \\
\text { interval } \\
\text { DSF (m) }\end{array}$ & $\begin{array}{l}\text { Bottom of } \\
\text { interval } \\
\text { DSF }(m)\end{array}$ & $\begin{array}{l}\text { Interval } \\
\text { advanced } \\
(\mathrm{m})\end{array}$ & $\begin{array}{c}\text { Core } \\
\text { recovered } \\
\text { length }(\mathrm{m})\end{array}$ & $\begin{array}{l}\text { Core } \\
\text { curated } \\
(\mathrm{m})\end{array}$ & $\begin{array}{c}\text { Recovery } \\
(\%)\end{array}$ & $\begin{array}{l}\text { Time on } \\
\text { deck UTC } \\
\text { (h) }\end{array}$ & $\begin{array}{l}\text { Time on deck } \\
\text { (ship local time; } \\
\text { UTC }+8 \text { h) }\end{array}$ & $\begin{array}{l}\text { Time to cut } \\
\text { core (min) }\end{array}$ & $\begin{array}{l}\text { Mud } \\
\text { pumped } \\
\text { (bbl) }\end{array}$ \\
\hline 51 & $\mathrm{R}$ & 1460.9 & 1470.5 & 9.6 & 4.99 & 4.99 & 52 & 24 Nov 20181555 & 24 Nov 20182355 & 180 & 30 \\
\hline 52 & $\mathrm{R}$ & 1470.5 & 1480.1 & 9.6 & 3.41 & 3.41 & 36 & 24 Nov 20182035 & 25 Nov 20180435 & 180 & \\
\hline 53 & $\mathrm{R}$ & 1480.1 & 1489.7 & 9.6 & 3.30 & 3.30 & 34 & 25 Nov 20180110 & 25 Nov 20180910 & 165 & 30 \\
\hline 54 & $\mathrm{R}$ & 1489.7 & 1499.3 & 9.6 & 6.05 & 6.05 & 63 & 25 Nov 20180435 & 25 Nov 20181235 & 90 & \\
\hline 55 & $\mathrm{R}$ & 1499.3 & 1508.8 & 9.5 & 3.94 & 3.94 & 41 & 25 Nov 20180900 & 25 Nov 20181700 & 155 & 30 \\
\hline 56 & $\mathrm{R}$ & 1508.8 & 1518.4 & 9.6 & 6.24 & 6.24 & 65 & 25 Nov 20181315 & 25 Nov 20182115 & 130 & 30 \\
\hline 57 & $\mathrm{R}$ & 1518.4 & 1528.0 & 9.6 & 1.20 & 1.20 & 13 & 25 Nov 20181950 & 26 Nov 20180350 & 270 & 30 \\
\hline 58 & $\mathrm{R}$ & 1528.0 & 1533.6 & 5.6 & 0.13 & 0.13 & 2 & 27 Nov 20181820 & 28 Nov 20180220 & 210 & 130 \\
\hline 59 & $\mathrm{R}$ & 1533.6 & 1538.1 & 4.5 & 0.15 & 0.15 & 3 & 27 Nov 20182330 & 28 Nov 20180730 & 195 & \\
\hline 60 & $\mathrm{R}$ & 1538.1 & 1542.7 & 4.6 & 0.25 & 0.25 & 5 & 28 Nov 20180510 & 28 Nov 20181310 & 230 & 30 \\
\hline 61 & $\mathrm{R}$ & 1542.7 & 1547.7 & 5.0 & 0.09 & 0.09 & 2 & 28 Nov 20181035 & 28 Nov 20181835 & 165 & \\
\hline 62 & $\mathrm{R}$ & 1547.7 & 1552.3 & 4.6 & 0.12 & 0.12 & 3 & 28 Nov 20181515 & 28 Nov 20182315 & 140 & 30 \\
\hline 63 & $\mathrm{R}$ & 1552.3 & 1557.3 & 5.0 & 0.17 & 0.17 & 3 & 28 Nov 20181900 & 29 Nov 20180300 & 130 & \\
\hline 64 & $\mathrm{R}$ & 1557.3 & 1561.9 & 4.6 & 0.13 & 0.13 & 3 & 28 Nov 20182240 & 29 Nov 20180640 & 115 & \\
\hline 65 & $\mathrm{R}$ & 1561.9 & 1566.9 & 5.0 & 0.16 & 0.16 & 3 & 29 Nov 20180205 & 29 Nov 20181005 & 95 & 30 \\
\hline 66 & $\mathrm{R}$ & 1566.9 & 1576.5 & 9.6 & 0.11 & 0.11 & 1 & 29 Nov 20180615 & 29 Nov 20181415 & 145 & \\
\hline 67 & $\mathrm{R}$ & 1576.5 & 1586.1 & 9.6 & 0.14 & 0.14 & 1 & 29 Nov 20181120 & 29 Nov 20181920 & 185 & 50 \\
\hline 68 & $\mathrm{R}$ & 1586.1 & 1595.7 & 9.6 & 0.29 & 0.29 & 3 & 29 Nov 20181605 & 30 Nov 20180005 & 170 & \\
\hline 69 & $\mathrm{R}$ & 1595.7 & 1605.0 & 9.3 & 2.35 & 2.54 & 25 & 29 Nov 20181955 & 30 Nov 20180355 & 135 & \\
\hline 70 & $\mathrm{R}$ & 1605.0 & 1610.5 & 5.5 & 1.26 & 1.28 & 23 & 30 Nov 20180020 & 30 Nov 20180820 & 150 & 60 \\
\hline 71 & $\mathrm{R}$ & 1610.5 & 1614.5 & 4.0 & 1.44 & 1.40 & 36 & 30 Nov 20180325 & 30 Nov 20181125 & 80 & \\
\hline 72 & $\mathrm{R}$ & 1614.5 & 1618.7 & 4.2 & 1.65 & 1.67 & 39 & 30 Nov 20180700 & 30 Nov 20181500 & 100 & 30 \\
\hline 73 & $\mathrm{R}$ & 1618.7 & 1623.7 & 5.0 & 2.25 & 2.06 & 45 & 30 Nov 20181035 & 30 Nov 20181835 & 100 & 0 \\
\hline 74 & $\mathrm{R}$ & 1623.7 & 1628.0 & 4.3 & 1.90 & 2.39 & 44 & 30 Nov 20181350 & 30 Nov 20182150 & 80 & 30 \\
\hline 75 & $\mathrm{R}$ & 1628.0 & 1633.0 & 5.0 & 0.83 & 1.03 & 17 & 30 Nov 20181915 & 01 Dec 20180315 & 105 & 150 \\
\hline 76 & $\mathrm{R}$ & 1633.0 & 1638.2 & 5.2 & 2.03 & 2.50 & 39 & 02 Dec 20181635 & 03 Dec 20180035 & 105 & 140 \\
\hline 77 & $\mathrm{R}$ & 1638.2 & 1643.2 & 5.0 & 1.92 & 2.31 & 38 & 02 Dec 20182000 & 03 Dec 20180400 & 95 & \\
\hline 78 & $\mathrm{R}$ & 1643.2 & 1647.7 & 4.5 & 3.86 & 4.66 & 86 & $02 \mathrm{Dec} 20182305$ & 03 Dec 20180705 & 85 & 30 \\
\hline 79 & $\mathrm{R}$ & 1647.7 & 1652.7 & 5.0 & 0.87 & 1.18 & 17 & 03 Dec 20180135 & 03 Dec 20180935 & 40 & \\
\hline 80 & $\mathrm{R}$ & 1652.7 & 1657.2 & 4.5 & 3.22 & 3.37 & 72 & 03 Dec 20180545 & 03 Dec 20181345 & 140 & 30 \\
\hline 81 & $\mathrm{R}$ & 1657.2 & 1662.2 & 5.0 & 2.10 & 2.93 & 42 & 03 Dec 20181345 & 03 Dec 20182145 & 50 & 40 \\
\hline 82 & $\mathrm{R}$ & 1662.2 & 1666.8 & 4.6 & 2.53 & 2.81 & 55 & 03 Dec 20181730 & 04 Dec 20180130 & 90 & 40 \\
\hline 83 & $\mathrm{R}$ & 1666.8 & 1671.8 & 5.0 & 4.40 & 5.57 & 88 & 03 Dec 20182250 & $04 \mathrm{Dec} 20180650$ & 200 & \\
\hline 84 & $\mathrm{R}$ & 1671.8 & 1676.4 & 4.6 & 4.71 & 5.18 & 102 & 04 Dec 20180230 & 04 Dec 20181030 & 120 & 40 \\
\hline 85 & $\mathrm{R}$ & 1676.4 & 1681.4 & 5.0 & 2.46 & 2.48 & 49 & $04 \mathrm{Dec} 20180545$ & $04 \mathrm{Dec} 20181345$ & 80 & 40 \\
\hline 86 & $\mathrm{R}$ & 1681.4 & 1691.0 & 9.6 & 1.18 & 1.62 & 12 & 04 Dec 20181015 & 04 Dec 20181815 & 160 & 40 \\
\hline 87 & $\mathrm{R}$ & 1691.0 & 1700.5 & 9.5 & 4.37 & 5.43 & 46 & 04 Dec 20181620 & $05 \mathrm{Dec} 20180020$ & 255 & 130 \\
\hline 88 & $\mathrm{R}$ & 1700.5 & 1710.1 & 9.6 & 4.53 & 4.53 & 47 & 04 Dec 20182225 & 05 Dec 20180625 & 230 & 200 \\
\hline \multicolumn{5}{|c|}{ Hole U1503A totals: } & 175.73 & 182.81 & 26 & & & & \\
\hline \multirow{2}{*}{\multicolumn{5}{|c|}{$\begin{array}{l}\text { Sedimentary section (Cores } 2 \mathrm{R}-69 \mathrm{R} \text { ) totals: } \\
\text { Basalt section (Cores } 69 \mathrm{R}-88 \mathrm{R} \text { ) totals: }\end{array}$}} & 128.22 & 128.41 & 20 & & & & \\
\hline & & & & & 47.51 & 54.40 & 47 & & & & \\
\hline
\end{tabular}

arrived at Site U1503 at $0900 \mathrm{~h}$ on 18 November, and the thrusters were lowered.

\section{Hole U1503A}

After arriving at Site U1503 at $0953 \mathrm{~h}$, the vessel shifted to dynamic positioning mode and the drill floor was cleared to begin operations in Hole U1503A. We did not deploy an acoustic positioning beacon, but one was prepared for immediate deployment if required.

The upper guide horn was removed, and a reentry funnel extension was lowered and secured in the moonpool. A four-stand RCB bottom-hole assembly (BHA) was assembled and lowered to 2990.0 meters below rig floor (mbrf). The subsea camera was deployed and run down the drill string while the drill string was deployed to 3874 mbrf. The search for the reentry system was quickly successful. The reentry cone was observed to be slightly below the level of the seafloor and full of debris from the previous drilling in the hole. The vessel was positioned for reentry, and the bit was lowered into the reentry cone at $0014 \mathrm{~h}$ on 19 November 2018. After several attempts to reenter the casing, the bit passed into the casing at $0039 \mathrm{~h}$.
The subsea camera system was recovered, and a FFF was welded to the top of the reentry funnel extension. The reentry FFF and extension were deployed down the outside of the drill pipe.

The upper guide horn was reinstalled, and the bit was lowered into the $103 / 4$ inch casing. The drill string was filled every 20 stands as the string was lowered toward the bottom of the casing. The driller tagged hard fill inside the casing at $956.0 \mathrm{~m}$. The top drive was picked up, and the driller washed down while pumping with slow rotation to $995.1 \mathrm{~m}$. Total depth was reached at $1600 \mathrm{~h}$ on 19 November. A 30 bbl high-viscosity sweep was circulated, and a nonmagnetic core barrel was deployed to begin RCB coring in Hole U1503A. Cores 368X-U1503A-2R through 40R (995.1-1364.9 m) were cored at a rate of just over $100 \mathrm{~m}$ per day, and recovery was generally poor (17\%). Recovery began to improve in Cores $41 \mathrm{R}$ through 51R (1364.9-1470.5 $\mathrm{m} ; 38 \%)$, and the penetration rate dropped to $<4 \mathrm{~m} / \mathrm{h}$.

Coring continued until $0400 \mathrm{~h}$ on 26 November and reached a depth of $1528.0 \mathrm{~m}$ with Core 368X-U1503A-57R. With $50.8 \mathrm{~h}$ on the bit, the hole was circulated clean with a $30 \mathrm{bbl}$ sweep of highviscosity mud. The bit was raised to $1383 \mathrm{~m}$ in the open hole (casing 
Figure F7. Reentry system and casing, Hole U1503A.

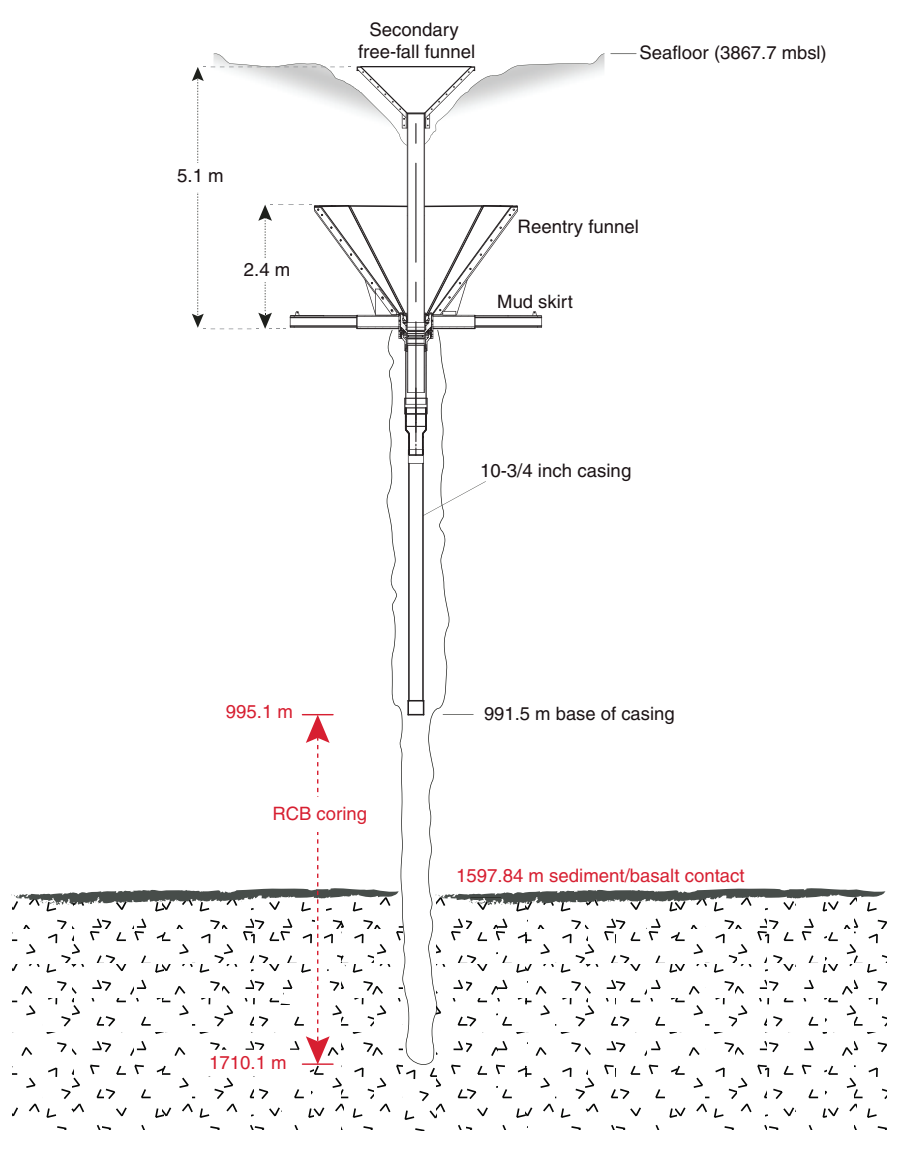

extends to $995.1 \mathrm{~m}$ ), and $200 \mathrm{bbl}$ of $10.5 \mathrm{lb} /$ gal heavy mud was displaced into the borehole. The heavy mud was used to increase the hydrostatic pressure on a very unstable section of hole. The top drive was set back, and the drill pipe was pulled back to $953.0 \mathrm{~m}$, just above the casing shoe. The upper guide horn was pulled up, and the subsea camera system was deployed.

While running the subsea camera system to just above the seafloor, a slip and cut of the drilling line was performed. The bit was pulled out of the hole at $1247 \mathrm{~h}$ and cleared the secondary funnel without issue. The measurement to the top of the cone was confirmed at 3879.7 mbrf. The subsea camera system was pulled back to the surface and secured on board. The remainder of the drill string was recovered, and the bit cleared the rig floor at $2045 \mathrm{~h}$ on 26 November. The outer core barrel was disassembled and inspected, and a new $\mathrm{C}-4$ bit was picked up and installed with a mechanical bit release (MBR).

The drill pipe was lowered to $3855 \mathrm{mbrf}$, and the subsea camera was deployed at $0545 \mathrm{~h}$. Hole U1503A was reentered at $0830 \mathrm{~h}$ on 27 November after $30 \mathrm{~min}$ of maneuvering. The subsea camera system was pulled back to the surface, and the trip back to bottom continued until the driller encountered a bridge at $1345.0 \mathrm{~m}$. The top drive was picked up, and the driller washed and reamed from $1345.0 \mathrm{~m}$ back to bottom at $1528.0 \mathrm{mbsf}$. After reaching total depth, the hole was circulated clean with high-viscosity mud. A nonmagnetic core barrel was dropped, and coring resumed at $2100 \mathrm{~h}$ on 27 November.

Coring with the second bit began with Core 368X-U1503A-58R and continued through Core 75R (1528.0-1633.0 m). Basement was reached at $1597.84 \mathrm{~m}$. After reaching basement, half cores were used to improve recovery. Basement recovery from 1605.0 to 1633.0 $\mathrm{m}$ was $33 \%$. With $42.2 \mathrm{~h}$ on the bit, the hole was circulated clean with three $50 \mathrm{bbl}$ sweeps of high-viscosity mud. The bit was raised to $1355.7 \mathrm{~m}$ in the open hole, and $200 \mathrm{bbl}$ of $10.5 \mathrm{lb} /$ gal heavy mud were displaced into the borehole to increase the hydrostatic pressure on the unstable section of the hole. The top drive was set back, and the drill pipe was recovered, clearing the seafloor at $1050 \mathrm{~h}$ on 1 December. After recovering the remaining drill pipe, the bit cleared the rig floor at $1725 \mathrm{~h}$. The outer core barrel was disassembled, cleaned, and inspected, and a new C-7 bit was picked up and installed with an MBR. The drill pipe was lowered to the seafloor, and the subsea camera system was deployed. After $60 \mathrm{~min}$ of maneuvering, Hole U1503A was reentered at 0439 h on 2 December, and the subsea camera system was pulled back to the surface.

The trip back to the bottom of Hole U1503A continued to $1375.0 \mathrm{~m}$, where the driller experienced a hard tag of the bit on a bridge. The top drive was picked up, and the driller washed and reamed from $1375.0 \mathrm{~m}$ back to the bottom until $1517.0 \mathrm{~m}$, where an electrical problem caused the top drive to stop operating. The problem was resolved, and $1.5 \mathrm{~h}$ later we began washing back to total depth. A wash core barrel was deployed at $1615 \mathrm{~m}$, and washing and reaming continued. Total depth $(1633.0 \mathrm{~m})$ was reached, and the hole was circulated clean with $40 \mathrm{bbl}$ of high-viscosity mud. The wash barrel was retrieved by wireline, and a nonmagnetic core barrel was dropped. Coring began again at $2100 \mathrm{~h}$ on 2 December.

Basement coring with the third bit began with Core 368XU1503A-76R at $1633.0 \mathrm{~m}$ and continued through Core $77 \mathrm{R}$ to $1657.3 \mathrm{~m}$ before high torque and excessive overpull were experienced and the driller was forced to work the drill string back to $1566.0 \mathrm{~m}$ to regain good circulation and rotation. The core barrel that had been dropped for Core 78R was retrieved, and the driller washed and reamed back to bottom $(1657.3 \mathrm{~m})$. A $40 \mathrm{bbl} \mathrm{mud}$ sweep was pumped down the drill string and circulated out to the seafloor. A core barrel was dropped, and half-coring began at 1657.3 $\mathrm{m}$ and continued through Core $88 \mathrm{R}$ to a final total depth of 1710.1 $\mathrm{m}$. All cores after Core $85 \mathrm{R}$ were full cores. High-viscosity mud sweeps were pumped frequently to help improve the hole conditions. The last core on deck was recorded at $0625 \mathrm{~h}$ on 5 December.

The hole was circulated clean, and we began pulling back with the top drive installed. High torque and overpull were observed while pulling back and reaming to $\sim 1600.0 \mathrm{~m}$. Backreaming continued to $1383.0 \mathrm{~m}$ while we continued to experience high torque and overpull. The hole was displaced with $200 \mathrm{bbl}$ of high-viscosity mud, and the bit was pulled back to $1355.0 \mathrm{~m}$. The top drive was set back, and the drill pipe was pulled back to the casing shoe, occasionally experiencing overpull as the hole collapsed around the drill string. After reaching the casing shoe at $995.1 \mathrm{~m}$, the remainder of the pipe trip to the seafloor was normal. The bit cleared the seafloor at $1450 \mathrm{~h}$ and was pulled $12.7 \mathrm{~m}$ above the reentry cone. The subsea camera system was installed, and while running the camera system to bottom the drilling line was slipped and $115 \mathrm{ft}$ of line was cut off. The top drive was picked up, and the sinker bars were inserted through the blocks. The rotary shifting tool (RST) was run to the bit and engaged to shift the retaining sleeve that activated the MBR. The subsea video camera recorded the bit release at $1920 \mathrm{~h}$ on 5 December. The wireline was pulled back to the surface, and the top drive was racked.

Hole U1503A was reentered at 2155 h on 5 December for the fourth time. The end of pipe (EOP) was set at $71.0 \mathrm{~m}$ in preparation for logging. After reentry, the subsea camera system was recovered to the surface at $0000 \mathrm{~h}$ on 5 December. A short delay was required 
to time the VSI experiment for daylight hours. Logging activities began at $0400 \mathrm{~h}$ on 6 December. The rig floor had been prepared for logging during the down period needed for seismic work to be done in daylight hours. The tools were rigged up, tested, and lowered into the pipe at $0430 \mathrm{~h}$.

Because the cable on the winch was new, standard cable seasoning/detorquing was conducted by pausing every $500 \mathrm{~m}$ as the tools were lowered into the pipe and pulling up a short distance before resuming the run-in hole. Upon reaching $3850.0 \mathrm{mbrf}$, a downlog was started as a rough depth reference. No other logs existed to tie into, so there was marginal uncertainty about the exact depth at which a gamma ray signal might begin to register, given that the original casing/cone sunk $\sim 5.1 \mathrm{~m}$ into the sediment and the cuttings stacked up to almost the top of the secondary cone. Lacking any better reference and prior to shooting any seismic stations, the log depth was adjusted in such a way that the top gamma ray reading occurred at the driller's seafloor depth of 3879 mbrf. The sole logging run for this expedition was with the VSI tool in the cased section of Hole U1503A. Open hole conditions were highly adverse, so no logs were conducted in the open hole portion of this site. The seismic-through-casing job began, as always, with a toolbox talk/safety meeting on the drill floor with the rig crew on duty. It was also noted that high-pressure air would be in use near the fantail for the air guns and that the fantail should therefore be avoided during seismic shooting.

The average heave was estimated to be $0.3 \mathrm{~m}$ just prior to logging. The active heave compensator was turned on when the VSI tool reached $3965.0 \mathrm{mbrf}$ and was utilized during each VSI station. The protective species watch began at $0630 \mathrm{~h}$. After an hour of observation, the soft start began. The seismic air gun cluster $(2 \times 250$ inch $^{3} \mathrm{G}$-guns in a horizontal array) was turned over to the Schlumberger wireline engineer at $0820 \mathrm{~h}$, and the seismic survey began.

The single tool string consisted of the following tools:

- VSI,

- Enhanced Digital Telemetry Cartridge (EDTC), and

- Logging equipment head-Q tension (LEH-QT).

The initial shots were taken at $975.9 \mathrm{~m}$ with additional stations every $50 \mathrm{~m}$ thereafter to $124.9 \mathrm{~m}$. No further stations could be recorded because the pipe was set inside the casing at $71.0 \mathrm{~m}$. All 18 viable stations were successfully shot and recorded. Moderate noise was present in some areas and most of the shots required manual transit time picking, but the overall data quality was quite reasonable and fit for interpretation.

A continuous gamma ray log was recorded from the bottom of the hole up past the seafloor. This log is the sole depth reference for the expedition and was planned and recorded in real time such that the topmost gamma ray activity would correspond with the driller's seafloor, thus tying the station measurements to the coring data as closely as possible under the circumstances. Once the gamma ray log was completed to $\sim 3860$ mbrf at $1055 \mathrm{~h}$ on 6 December, the tools were pulled out of the hole, were at the surface at $1330 \mathrm{~h}$, and were rigged down by $1400 \mathrm{~h}$, which concluded the logging run.

The drill string was pulled out of the hole to the surface, clearing the seafloor at $1450 \mathrm{~h}$ on 6 December. By $2345 \mathrm{~h}$, all rig floor equipment was secured, ending Hole U1503A and Site U1503. The thrusters and hydrophones were raised, and the vessel began the transit to Hong Kong at $0030 \mathrm{~h}$ on 7 December. A total of $444.25 \mathrm{~h}$ (18.5 days) were recorded for operations in Hole U1503A during Expedition 368X. One downtime incident occurred during the period; an electrical malfunction caused the top drive to shut down for $1.5 \mathrm{~h}$ while the problem was repaired. After the $284 \mathrm{nmi}$ transit to Hong Kong, which averaged $9.4 \mathrm{kt}$, the vessel arrived at the pilot station. The pilot arrived on board at $0654 \mathrm{~h}$, and the first line ashore $0754 \mathrm{~h}$ on 8 December ended Expedition 368X.

\section{Lithostratigraphy}

Hole U1503A penetrated 602.74 m (995.1-1597.8 m) of unconsolidated to lithified sediments and sedimentary rocks and recovered $128 \mathrm{~m}$. Deeper than $1597.8 \mathrm{~m}, 112.26 \mathrm{~m}$ of the underlying basalts were cored to $1710.1 \mathrm{~m}$ and $47.51 \mathrm{~m}$ were recovered. We organized the lithostratigraphy into four units (Figure F8). Lithostratigraphic Unit I is composed of interbedded dark brownish gray

Figure F8. Lithostratigraphic summary, Hole U1503A.

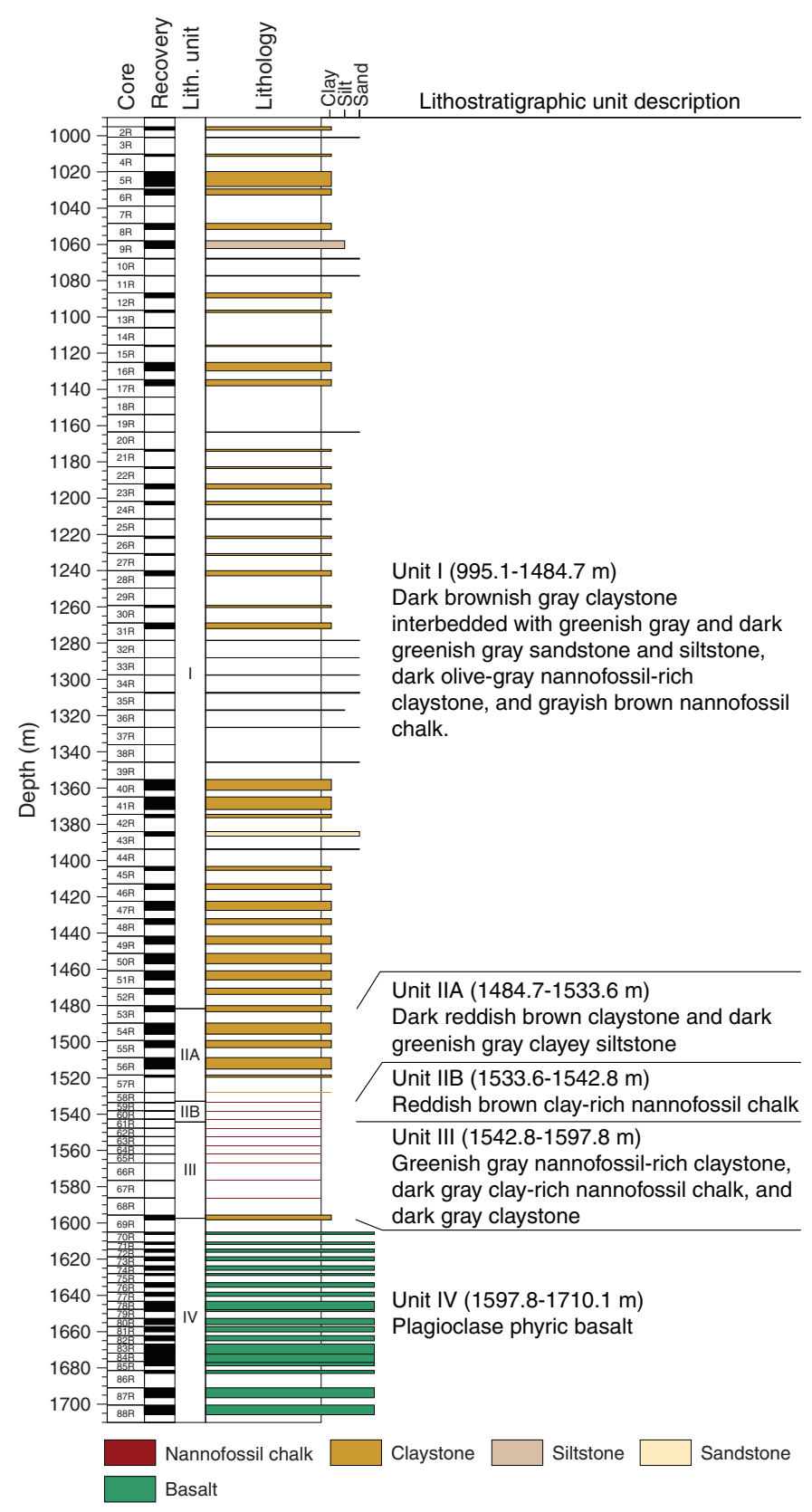


Figure F9. Lithostratigraphic units correlated with physical properties and carbonate content, Hole U1503A. MS = magnetic susceptibility.

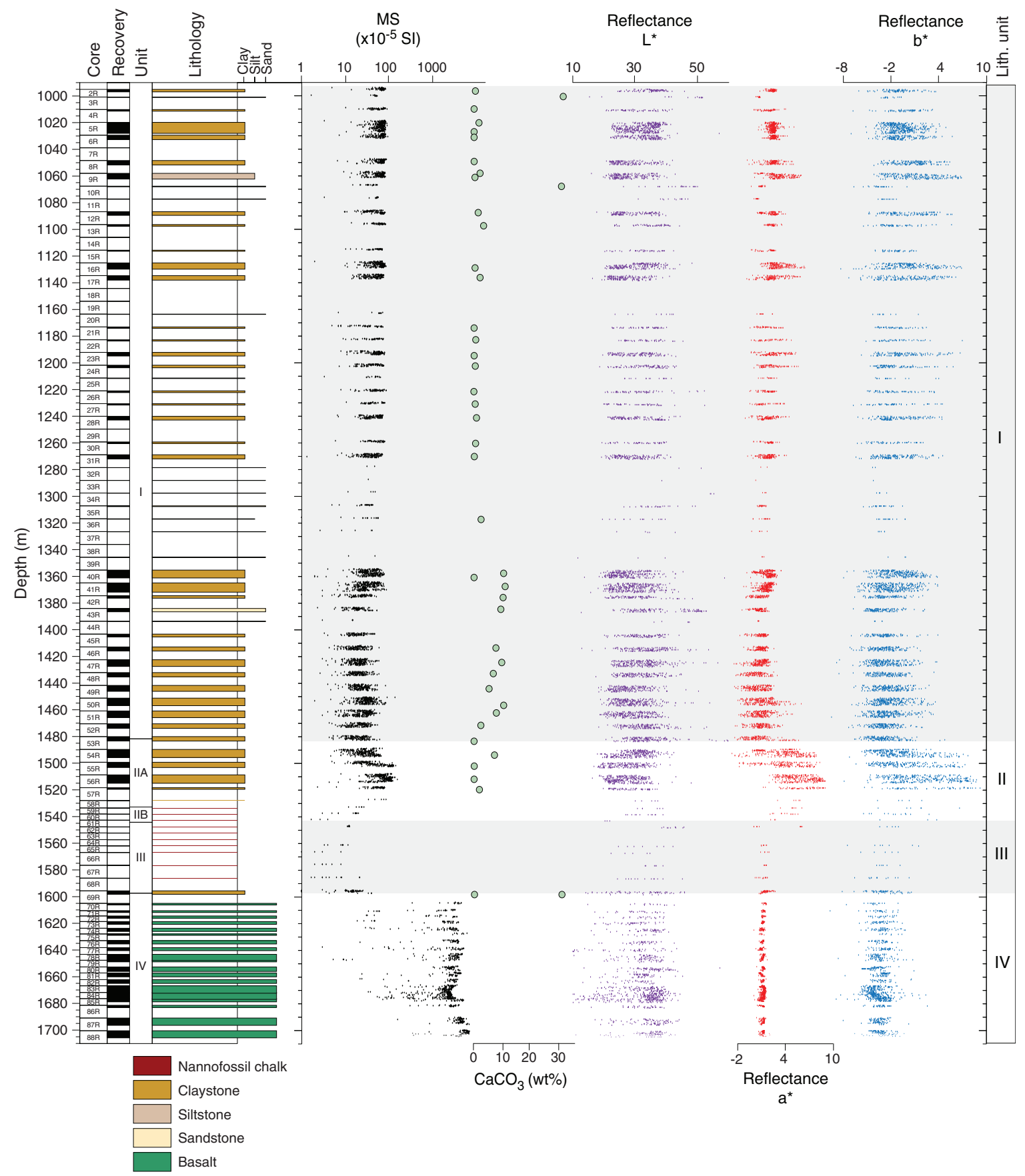

claystone, silty claystone and clayey siltstone, greenish gray siltstone, dark greenish gray sandstone, dark olive-gray nannofossilrich claystone, and grayish brown nannofossil chalk. Unit II is composed of dark reddish brown claystone that transitions to a reddish brown clay-rich chalk. Unit III contains greenish gray nannofossilrich claystone and dark gray claystone, both of which are heavily bioturbated. Unit IV is composed of basalt with occasional gray claystone inclusions. Lithostratigraphic units and subunits were primarily defined by principal lithology and the repetitive assemblages of facies that occur in each unit (see the Expedition 367/368 methods chapter [Sun et al., 2018a]) and were subsequently corroborated using physical property measurements (Figure F9), mineralogical data from X-ray diffraction (XRD; see XRD in Supplementary material [Sun et al., 2018b]) (Figure F10), pXRF (Figure F11), and calcium carbonate contents (Figure F9). Because core recovery was extremely poor across most of the boundaries that separate individual lithostratigraphic units, precise depths can only be inferred.

\section{Unit descriptions}

\section{Unit I}

Interval: $368 \mathrm{X}-\mathrm{U} 1503 \mathrm{~A}-2 \mathrm{R}-1,0 \mathrm{~cm}$, to $53 \mathrm{R}-2,113 \mathrm{~cm}$ Depth: 995.10-1484.74 m (0-991.50 m cased)

Age: late Miocene-middle Miocene 


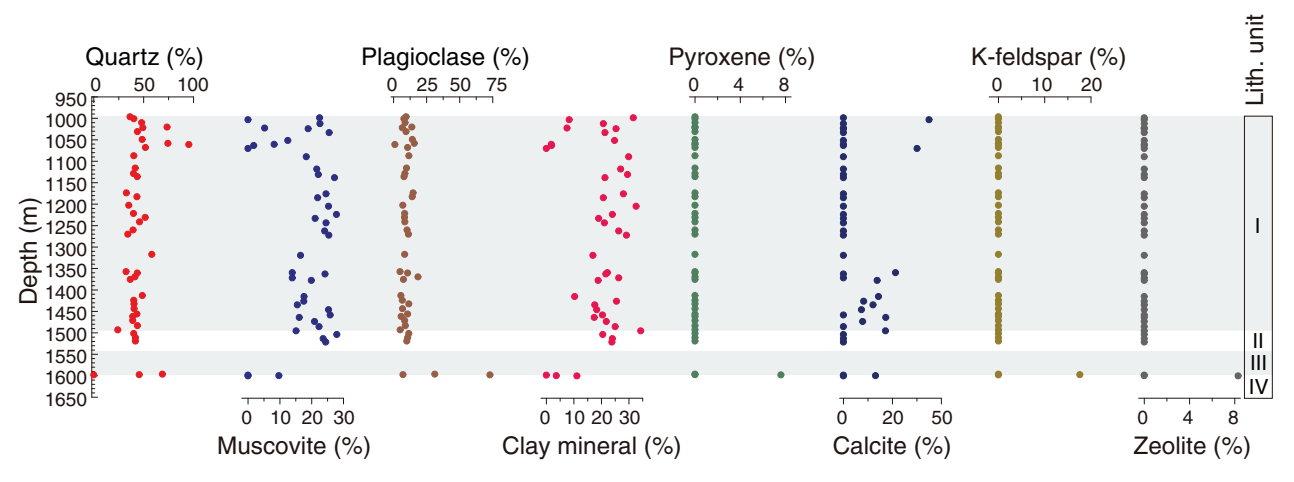

The relatively low recovery (21\%) of lithostratigraphic Unit I is attributed to the presence of thick sand or sandstone layers inferred from the high-amplitude reflectivity of the seismic section. The recovered sediment and sedimentary rock from Unit I is mainly composed of consolidated to lithified claystone, silty claystone, and clayey siltstone interbedded with greenish gray and dark greenish gray sandstone and siltstone layers (Figure F12A). There are dark olive-gray nannofossil-rich claystone and grayish brown nannofossil chalk intervals from Core 368X-U1503A-41R through Section 53R2 . The claystone, silty claystone, and clayey siltstone are moderately to heavily bioturbated (Figure F12C, F12D) and have color variations of dark reddish brown, dark greenish gray, dark gray, and dark grayish brown. Two types of sandstone (Figure F12B) are differentiated based on color, carbonate content, and sedimentary structures. The greenish gray sandstone is well sorted and massive and has relatively higher carbonate content. Thin sections from this lithology (Figure F12I) show subangular quartz and plagioclase in a carbonate cement. The dark greenish gray sandstone contains finingupward sequences and mudstone intraclasts. Siltstone interval frequency increases downhole, and the intervals contain cross-, parallel, and convolute lamination (Figure F12F, F12G). The lithologies are arranged in repetitive sequences with sandstone or siltstone basal intervals overlain by a gradational sequence from clayey siltstone to silty claystone and claystone. The repetitive fining upward sequences and the presence of tractional sedimentary structures in the coarser material indicate that the much of the sediment of lithostratigraphic Unit I was transported by deep-sea turbiditic flows.

pXRF data were collected throughout lithostratigraphic Unit I (Figure F11). Dark reddish brown claystone intervals generally have higher Fe content relative to all other lithologies. In intervals with heavier bioturbation, Fe content is usually relatively lower and $\mathrm{Ca}$ and $\mathrm{Al}$ contents are higher. Greenish gray sandstone usually contains a higher percentage of $\mathrm{Ca}$ and $\mathrm{Sr}$, whereas dark greenish gray sandstone has higher $\mathrm{Al}, \mathrm{Si}$, and $\mathrm{Mg}$ contents and lower Ca content. The bulk mineralogy of Unit I, as measured by XRD, consists mainly of quartz (32.4\%-95.3\%), plagioclase (1.0\%-18.5\%), muscovite $(0 \%-27.8 \%)$, and clay minerals (including kaolinite, chlorite, and illite; 0\%-32.6\%) (Figure F10; Table T2). Calcite was not detected by XRD in most samples; however, ten samples contain $\sim 10 \%-40 \%$ calcite. Of those ten samples, eight are located deeper than 1350.0 $\mathrm{m}$. Moreover, carbonate (inferred as calcite) content covaries with lithology; namely, the greenish gray sandstone intervals have higher calcite content than the claystone.

The magnetic susceptibility of lithostratigraphic Unit I ranges from $10 \times 10^{-5}$ to $158 \times 10^{-5} \mathrm{SI}$ with an average of $41 \times 10^{-5} \mathrm{SI}$. A decrease in average magnetic susceptibility to $25 \times 10^{-5}$ SI was observed between Cores 368X-U1503A-41R and 53R. Relatively lower color reflectance $\mathrm{a}$ * was also observed in Cores 41R and 53R (Figure F9). Color reflectance $L^{*}$ is greater in sandstone intervals, which is consistent with high carbonate content. The increase in carbonate content, decrease in magnetic susceptibility, and change in color reflectance from Core 41R through the deeper sediments and sedimentary rocks correlate with the increase in nannofossil-rich lithologies.

\section{Unit II}

Interval: 368X-U1503A-53R-2, $113 \mathrm{~cm}$, to $61 \mathrm{R}-\mathrm{CC}, 7 \mathrm{~cm}$

Depth: $1484.74-1542.77 \mathrm{~m}$

Age: middle Miocene-late Oligocene

The contact between lithostratigraphic Units I and II is gradational from Core 368X-U1503A-53R through Core 55R with alternating dark reddish brown and greenish gray claystone (Figure F13). The contact is placed where the abundance of siltstone and sandstone in Unit I noticeably decreases and the overall sediment color changes to reddish brown in Unit II. The recovery of this unit is variable $(2 \%-65 \%$; average $=25 \%)$. Unit II is divided into two subunits based on carbonate and nannofossil content.

\section{Subunit IIA}

Interval: 368X-U1503A-53R-2, $113 \mathrm{~cm}$, to 58R-CC, $13 \mathrm{~cm}$ Depth: $1484.74-1533.60 \mathrm{~m}$

Age: middle Miocene-early Miocene

Lithostratigraphic Subunit IIA consists of well-consolidated dark reddish brown claystone, silty claystone and clayey siltstone with heavy bioturbation, and slightly inclined dark greenish gray clayey siltstone intervals. Some of the claystone intervals are massive, but there are repeated fining up intervals from clayey siltstone to claystone interpreted to be turbidites. There are greenish halos around foraminifer tests and other fossil fragments. Interval 368XU1503A-55R-2, 97-99 cm is $2 \mathrm{~cm}$ of light greenish gray, highly bioturbated nannofossil chalk.

Element contents in pXRF measurements (Figure F11) in Subunit IIA suggest that carbonate content in the dark reddish brown claystone intervals is generally very low $(<1 \%)$ but $\mathrm{Sr}, \mathrm{Fe}, \mathrm{Ni}, \mathrm{Zn}$, and $\mathrm{Al}$ contents are relatively high. Calcium content is as much as $25 \%$ in intervals where burrows are visible. The discrete XRD samples taken from Subunit IIA are composed mainly of quartz (25\%-45\%), plagioclase $(5 \%-12 \%)$, muscovite $(15 \%-30 \%)$, and clay minerals. 
Figure F11. pXRF element abundances, Hole U1503A.

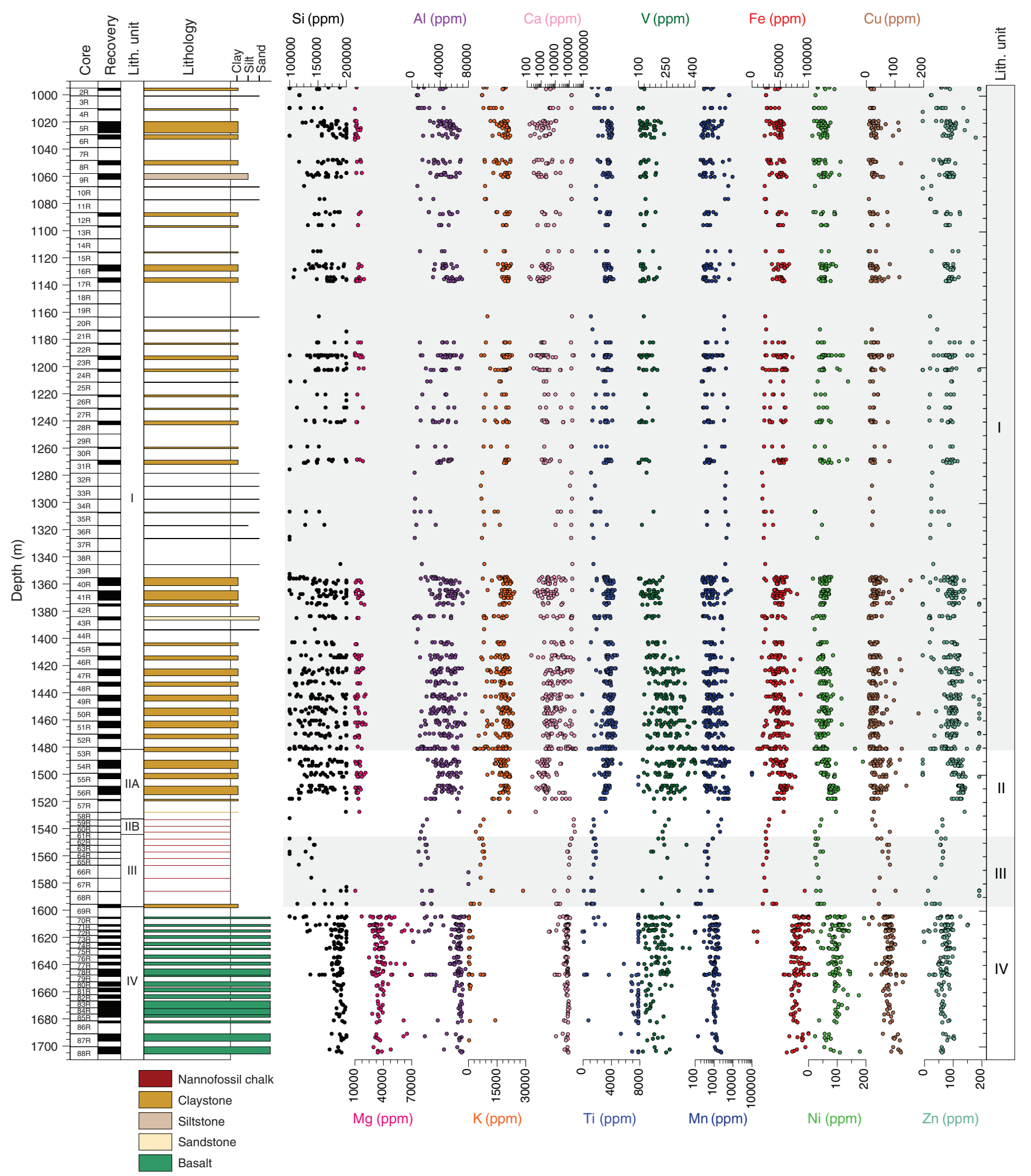

Only one sample (368X-U1503A-54R-3, 53-55 cm) is dominated by carbonate $(\sim 20 \%)$ with $<25 \%$ quartz (Figure F10).

Magnetic susceptibility is variable throughout lithostratigraphic Subunit IIA, with lower values at the top of the subunit $\left(0 \times 10^{-5}\right.$ to $\left.67 \times 10^{-5} \mathrm{SI}\right)$ and an increase below Core 368X-U1503A-54R $(0 \times$ $10^{-5}$ to $158 \times 10^{-5} \mathrm{SI}$ ) (Figure F9). Higher magnetic susceptibility below Core 368X-U1503A-54R is possibly related to the increased Fe content observed in pXRF measurements (Figure F11). L* reflectance data range from 16 to 47 throughout the subunit, and the highest values are found in the coarser intervals. Color reflectance $a^{*}$ is positive throughout the subunit (average $=4.6$ ), which correlates well with the dominant reddish color. 
Figure F12. Sedimentary structures from Unit I, Hole U1503A. A. Fining-upward sequence from massive medium-grained sandstone to laminated silty finegrained sandstone. The sequence is overlain by the planar base of the next fining-upward interval. B. Dark brownish gray laminated clayey siltstone with sand over dark greenish gray sandstone with a low carbonate content. This lithology is underlain by greenish gray sandstone with a high carbonate content. The laminated clayey siltstone with sand has claystone intraclasts. C. Two fining-upward sequences with claystone overlain by laminated clayey siltstone, laminated silty claystone, and claystone. The laminated clayey siltstone has a sharp base that overlies the claystone. The intensity of bioturbation increases upward in the fining-upward sequence. D. Inclined burrow filled with light gray silty sediment cutting across olive-gray, highly bioturbated claystone. E. Sandstone with claystone intraclasts overlain by claystone. F. Convolute and plane laminations in silty fine sandstone. G. Parallel laminations in fine sandstone. H. Greenish gray massive and well-sorted sandstone. Blue star = location of image in I. I. Thin section image of sandstone in $\mathrm{H}$ with subangular quartz (Qtz), plagioclase (PI), muscovite $(M)$, and a foraminifer $(F)$ in carbonate cement.
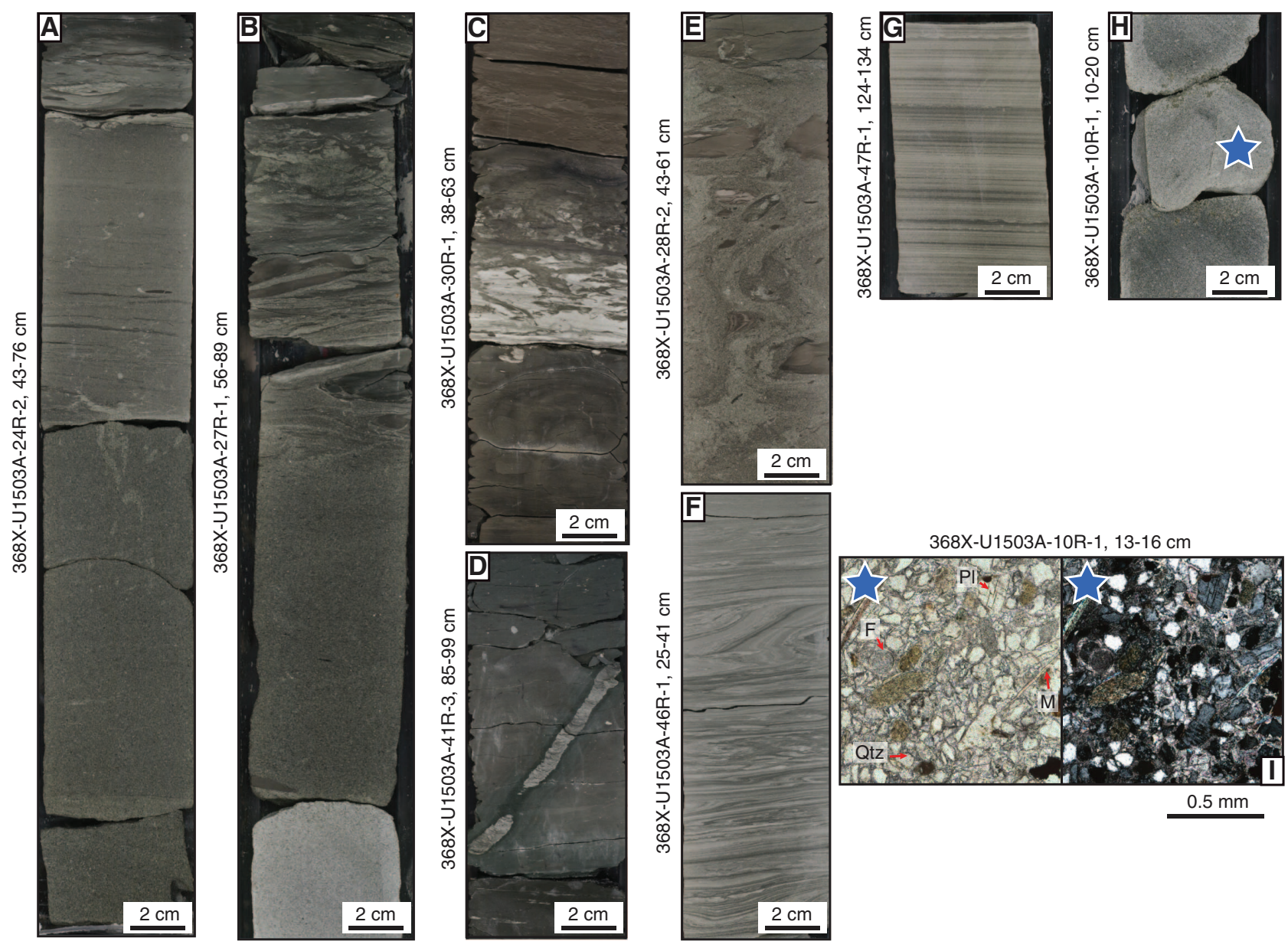

Subunit IIB

Interval: 368X-U1503A-58R-CC, $13 \mathrm{~cm}$, to $61 \mathrm{R}-\mathrm{CC}, 7 \mathrm{~cm}$

Depth: $1533.60-1542.77 \mathrm{~m}$

Age: early Miocene-late Oligocene

Only $48 \mathrm{~cm}$ of reddish brown clay-rich nannofossil chalk was recovered. However, lithostratigraphic Subunit IIB was defined based on physical property data and following the description of Site U1500 (see the Site U1500 chapter [Stock et al., 2018]). Smear slides contain abundant to dominant calcareous nannofossils that correlate with an increase in carbonate content observed in pXRF measurements in Section 368X-U1503A-59R-CC.

Element abundances (pXRF) shift noticeably between Sections 368X-U1503A-58R-CC and 59R-CC. Si, Al, K, Ti, Fe, Ni, and Zn contents decrease by $2-3$ times, and $\mathrm{Ca}, \mathrm{V}, \mathrm{Mn}, \mathrm{Sr}$, and $\mathrm{Cu}$ increase by 2-5 times (Figure F11). Ca is the primary component of these sediments (as much as $25 \%$ ). Because of poor recovery, no discrete XRD samples were collected in this subunit.

Magnetic susceptibility is very low throughout the subunit and ranges from $3 \times 10^{-5}$ to $27 \times 10^{-5} \mathrm{SI}$. This low magnetic susceptibility is possibly related to the decrease in Fe content and the increase in carbonate content (Figures F9, F11). L* reflectance is low and ranges between 2 and 5 (average $=\sim 4$ ). Average color reflectance $\mathrm{a}^{*}$ is negative (-0.45), and average color reflectance $b^{*}$ is positive (7.2) (Figure F9).

\section{Unit III}

Interval: 368X-U1503A-61R-CC, $7 \mathrm{~cm}$, to 69R-2, $96 \mathrm{~cm}$

Depth: 1542.77-1597.84 m

Age: late Oligocene to early Oligocene

Lithostratigraphic Unit III contains heavily bioturbated lithified greenish gray nannofossil-rich claystone, nannofossil-rich claystone with foraminifers, greenish gray claystone, light greenish gray clayey siltstone and siltstone, dark gray nannofossil-rich laminated silty claystone, nannofossil-rich silty claystone with foraminifers, nanno- 
Table T2. Bulk mineralogy of sediments, Site U1503. Download table in CSV format.

\begin{tabular}{|c|c|c|c|c|c|c|c|c|c|c|c|}
\hline Lith. unit & $\begin{array}{l}\text { Core, section, } \\
\text { interval }(\mathrm{cm})\end{array}$ & Lithology & $\begin{array}{l}\text { Depth } \\
(\mathrm{m})\end{array}$ & $\begin{array}{l}\text { Quartz } \\
(\%)\end{array}$ & $\begin{array}{l}\text { Muscovite } \\
\text { (\%) }\end{array}$ & $\begin{array}{l}\text { Plagioclase } \\
\text { (\%) }\end{array}$ & $\begin{array}{c}\text { Clay } \\
\text { minerals } \\
(\%)\end{array}$ & $\begin{array}{l}\text { Carbonate } \\
\text { (\%) }\end{array}$ & $\begin{array}{l}\text { K-feldspar } \\
\text { (\%) }\end{array}$ & $\begin{array}{c}\text { Clinopyroxene } \\
\text { (\%) }\end{array}$ & $\begin{array}{c}\text { Zeolite } \\
(\%)\end{array}$ \\
\hline \multirow{36}{*}{$\begin{array}{c}\mathrm{I} \\
(996.1-1484.7 \mathrm{~m})\end{array}$} & 368X-U1503A- & & & & & & & & & & \\
\hline & $2 \mathrm{R}-2,12-15$ & Claystone & 996.46 & 36.4 & 22.5 & 9.5 & 31.6 & 0.0 & 0.0 & 0.0 & 0.0 \\
\hline & $3 R-1,7-9$ & Sandstone & 1000.87 & 40.2 & 0.0 & 7.8 & 8.3 & 43.7 & 0.0 & 0.0 & 0.0 \\
\hline & $4 R-1,5-7$ & Claystone & 1010.25 & 48.0 & 22.6 & 8.7 & 20.7 & 0.0 & 0.0 & 0.0 & 0.0 \\
\hline & $5 R-1,68-70$ & Sandstone & 1020.48 & 73.5 & 5.2 & 13.8 & 7.5 & 0.0 & 0.0 & 0.0 & 0.0 \\
\hline & 5R-2, 101-103 & Claystone & 1021.98 & 49.2 & 18.9 & 6.6 & 25.3 & 0.0 & 0.0 & 0.0 & 0.0 \\
\hline & $6 \mathrm{R}-2,40-42$ & Claystone & 1031.04 & 43.8 & 25.5 & 9.4 & 21.3 & 0.0 & 0.0 & 0.0 & 0.0 \\
\hline & $8 R-1,92-94$ & Claystone & 1049.32 & 48.5 & 12.5 & 14.2 & 24.8 & 0.0 & 0.0 & 0.0 & 0.0 \\
\hline & $9 \mathrm{R}-1,38-40$ & Sandstone & 1058.38 & 74.3 & 8.2 & 15.7 & 1.8 & 0.0 & 0.0 & 0.0 & 0.0 \\
\hline & $9 \mathrm{R}-3,16-18$ & Claystone & 1061.02 & 95.3 & 1.8 & 1.0 & 1.9 & 0.0 & 0.0 & 0.0 & 0.0 \\
\hline & $10 \mathrm{R}-1,30-32$ & Sandstone & 1067.90 & 51.8 & 0.0 & 10.6 & 0.0 & 37.6 & 0.0 & 0.0 & 0.0 \\
\hline & $12 \mathrm{R}-1,43-45$ & Claystone & 1087.23 & 40.2 & 18.3 & 11.6 & 29.9 & 0.0 & 0.0 & 0.0 & 0.0 \\
\hline & $15 \mathrm{R}-1,30-32$ & Claystone & 1115.90 & 41.6 & 21.6 & 9.8 & 27.0 & 0.0 & 0.0 & 0.0 & 0.0 \\
\hline & $16 R-3,78-80$ & Claystone & 1128.74 & 39.8 & 22.1 & 8.6 & 29.5 & 0.0 & 0.0 & 0.0 & 0.0 \\
\hline & 17R-1, 133-135 & Claystone & 1136.03 & 43.6 & 27.2 & 7.9 & 21.3 & 0.0 & 0.0 & 0.0 & 0.0 \\
\hline & $21 \mathrm{R}-1,76-78$ & Claystone & 1173.86 & 32.7 & 24.5 & 14.8 & 28.0 & 0.0 & 0.0 & 0.0 & 0.0 \\
\hline & $22 \mathrm{R}-1,18-20$ & Claystone & 1182.88 & 43.3 & 21.9 & 14.1 & 20.7 & 0.0 & 0.0 & 0.0 & 0.0 \\
\hline & $24 \mathrm{R}-1,81-83$ & Claystone & 1202.61 & 35.1 & 25.3 & 7.0 & 32.6 & 0.0 & 0.0 & 0.0 & 0.0 \\
\hline & $26 \mathrm{R}-1,65-67$ & Claystone & 1221.65 & 39.8 & 27.8 & 8.4 & 24.0 & 0.0 & 0.0 & 0.0 & 0.0 \\
\hline & $27 \mathrm{R}-1,30-32$ & Claystone & 1230.90 & 51.6 & 21.1 & 8.3 & 19.0 & 0.0 & 0.0 & 0.0 & 0.0 \\
\hline & $28 \mathrm{R}-2,5-7$ & Claystone & 1241.39 & 45.9 & 24.5 & 8.5 & 21.1 & 0.0 & 0.0 & 0.0 & 0.0 \\
\hline & $30 \mathrm{R}-1,93-95$ & Claystone & 1260.23 & 39.4 & 24.1 & 10.2 & 26.3 & 0.0 & 0.0 & 0.0 & 0.0 \\
\hline & $31 \mathrm{R}-2,10-12$ & Claystone & 1270.17 & 34.2 & 25.4 & 11.3 & 29.1 & 0.0 & 0.0 & 0.0 & 0.0 \\
\hline & $36 \mathrm{R}-1,18-20$ & Siltstone & 1317.08 & 58.2 & 16.5 & 8.4 & 16.9 & 0.0 & 0.0 & 0.0 & 0.0 \\
\hline & 40R-2, 103-105 & Claystone & 1357.46 & 32.4 & 13.9 & 4.9 & 22.2 & 26.6 & 0.0 & 0.0 & 0.0 \\
\hline & $40 R-5,20-22$ & Claystone & 1360.52 & 43.6 & 24.2 & 10.6 & 21.6 & 0.0 & 0.0 & 0.0 & 0.0 \\
\hline & $41 \mathrm{R}-4,20-22$ & Claystone & 1369.55 & 41.3 & 13.9 & 18.5 & 26.3 & 0.0 & 0.0 & 0.0 & 0.0 \\
\hline & $42 \mathrm{R}-1,110-112$ & Claystone & 1375.60 & 36.6 & 19.9 & 7.5 & 18.8 & 17.2 & 0.0 & 0.0 & 0.0 \\
\hline & $46 \mathrm{R}-1,11-13$ & Siltstone & 1413.01 & 48.7 & 17.6 & 5.5 & 10.3 & 17.9 & 0.0 & 0.0 & 0.0 \\
\hline & $47 \mathrm{R}-2,15-17$ & Claystone & 1424.03 & 40.1 & 17.5 & 6.6 & 25.5 & 10.3 & 0.0 & 0.0 & 0.0 \\
\hline & $48 \mathrm{R}-1,46-48$ & Claystone & 1432.56 & 40.3 & 15.5 & 11.5 & 17.6 & 15.1 & 0.0 & 0.0 & 0.0 \\
\hline & 49R-2, 59-61 & Claystone & 1443.79 & 40.4 & 25.3 & 6.8 & 18.3 & 9.2 & 0.0 & 0.0 & 0.0 \\
\hline & $50 \mathrm{R}-4,45-47$ & Claystone & 1456.07 & 43.2 & 25.8 & 10.6 & 20.4 & 0.0 & 0.0 & 0.0 & 0.0 \\
\hline & $51 \mathrm{R}-1,86-88$ & Claystone & 1461.76 & 39.1 & 16.1 & 5.7 & 17.4 & 21.6 & 0.0 & 0.0 & 0.0 \\
\hline & $52 \mathrm{R}-1,69-71$ & Claystone & 1471.19 & 39.1 & 20.9 & 8.4 & 21.8 & 9.8 & 0.0 & 0.0 & 0.0 \\
\hline & $53 \mathrm{R}-\mathrm{CC}, 14-16$ & Claystone & 1483.28 & 43.8 & 22.3 & 8.9 & 25.0 & 0.0 & 0.0 & 0.0 & 0.0 \\
\hline \multirow{4}{*}{$\begin{array}{c}\| \\
(1484.7-1542.8 \mathrm{~m})\end{array}$} & $54 R-3,53-55$ & Claystone & 1493.14 & 24.1 & 15.1 & 5.0 & 34.3 & 21.5 & 0.0 & 0.0 & 0.0 \\
\hline & $55 \mathrm{R}-2,88-90$ & Claystone & 1501.61 & 40.1 & 27.9 & 11.5 & 20.5 & 0.0 & 0.0 & 0.0 & 0.0 \\
\hline & 56R-2, 97-99 & Claystone & 1511.23 & 41.8 & 23.6 & 10.7 & 24.0 & 0.0 & 0.0 & 0.0 & 0.0 \\
\hline & 57R-1,91-93 & Claystone & 1519.31 & 41.8 & 24.4 & 10.0 & 23.8 & 0.0 & 0.0 & 0.0 & 0.0 \\
\hline III & $69 \mathrm{R}-1,70-72$ & Claystone & 1596.40 & 68.8 & 0.0 & 31.2 & 0.0 & 0.0 & 0.0 & 0.0 & 0.0 \\
\hline (1542.8-1597.8 m) & $69 R-2,64-65$ & Claystone & 1597.52 & 45.6 & 9.7 & 7.1 & 3.6 & 16.4 & 17.6 & 0.0 & 0.0 \\
\hline
\end{tabular}

fossil-rich silty claystone with pyrite, and clay-rich nannofossil chalk. Recovery in Unit III is extremely low (5\%). A greenish black interval, Section 368X-U1503A-68R-CC (TS02; 1586.30$1586.34 \mathrm{~m}$ ), has a foliation defined by chlorite and abundant sulfide minerals (Figure F14). The alteration and bioturbation make it difficult to interpret how the interval formed. The chlorite might be replacing volcanic ash, or the interval might be a zone of hydrothermal alteration. Core 69R contains nannofossil-rich claystone, nannofossil-rich silty claystone with foraminifers, and clay-rich nannofossil chalk with alternating dark gray and light greenish gray bands dipping $\sim 30^{\circ}$. There are thin, light greenish gray intervals of nannofossil-rich clayey siltstone. All lithologies have heavy bioturbation. In interval $69 \mathrm{R}-1,22-26 \mathrm{~cm}$, a set of millimeter-scale normal faults occurs in a finely laminated clayey siltstone.

Element abundances determined by pXRF are similar in range to those in lithostratigraphic Subunit IIB. Ca, V, Mn, and Cu contents are high, but $\mathrm{Si}, \mathrm{Al}, \mathrm{K}$, and $\mathrm{Fe}$ contents are low. One exception occurs in Sample 68R-CC, $22 \mathrm{~cm}$, where high S, K, Fe, and Rb and low $\mathrm{Al}, \mathrm{Mg}, \mathrm{Ca}, \mathrm{Ti}, \mathrm{Mn}$, and $\mathrm{Zn}$ were detected, which may corre- spond to the greenish black interval. XRD measurements were taken in the dark gray claystone and greenish gray claystone of Samples 69R-1, 70-72 cm, and 69R-2, 64-65 cm. The dark gray claystone is composed of $68.8 \%$ quartz and $31.2 \%$ plagioclase, and the greenish gray claystone is composed of $45.6 \%$ quartz, $17.6 \% \mathrm{~K}-$ feldspar, $16.4 \%$ calcite, $9.7 \%$ muscovite, and minor plagioclase and clay minerals.

$L^{*}$ reflectance ranges from 14 to 45 and averages $\sim 33$. Color reflectance $\mathrm{a}^{*}$ averages 1.7, and color reflectance $\mathrm{b}^{*}$ averages -1.9 . Magnetic susceptibility is very low on average $\left(10 \times 10^{-5} \mathrm{SI}\right)$ and ranges from 0 to $25 \times 10^{-5}$ SI (Figure F9).

\section{Unit IV}

Interval: 368X-U1503A-69R-2, $96 \mathrm{~cm}$, to $88 \mathrm{R}-4,130 \mathrm{~cm}$ Depth: $1597.84-1710.10 \mathrm{~m}$

Age: early Oligocene (older than 29-30 Ma)

Unit IV comprises basalt and is further divided into three subunits based on flow morphology and XRF compositional data (see 
Figure F13. Gradual transition from Unit I to Unit II with alternating greenish gray and dark reddish brown claystone, silty claystone, and clayey siltstone, Hole U1503A. White dashed line = Unit I/II boundary.

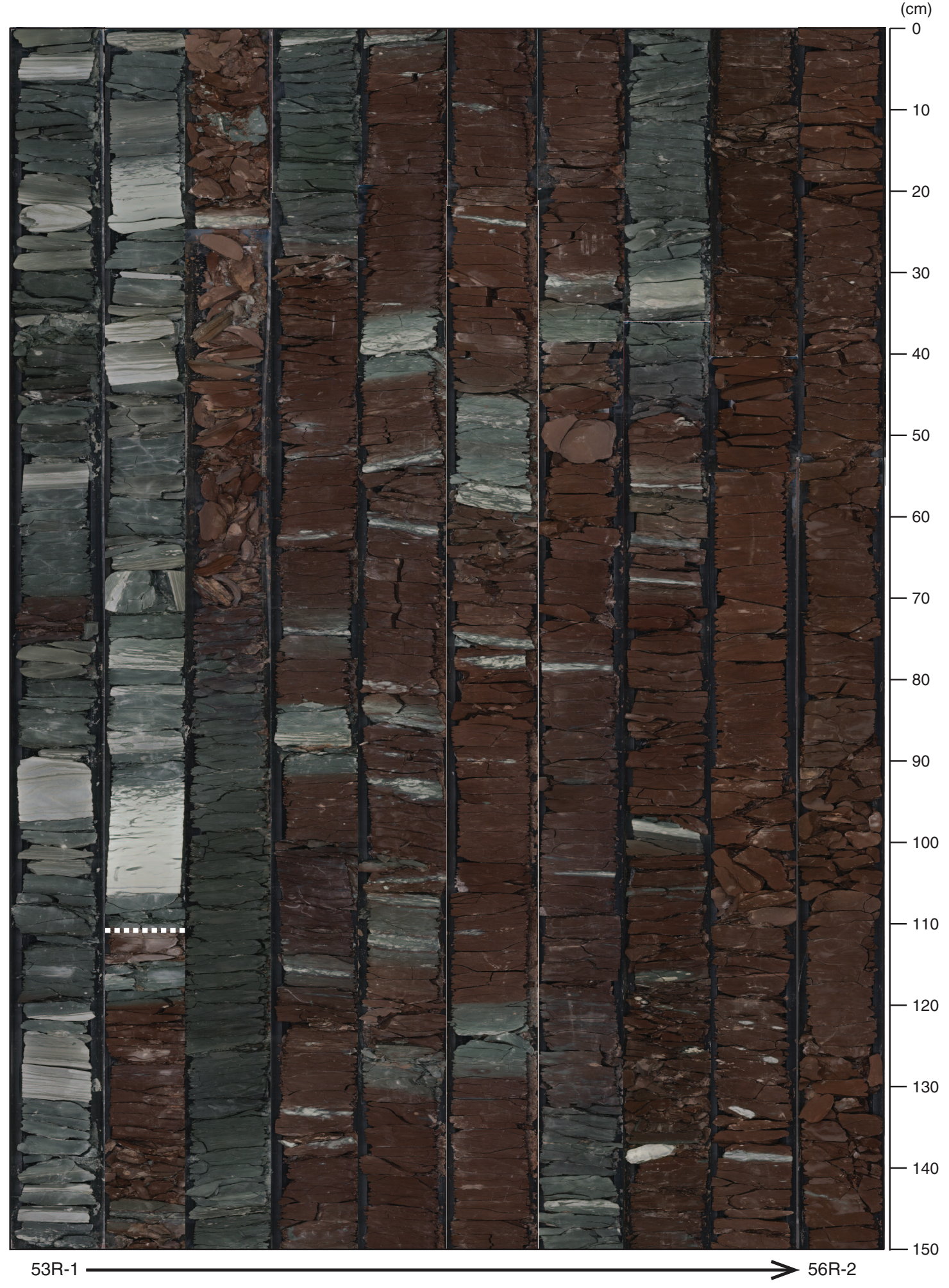


Figure F14. Sedimentary and deformation structures, Hole U1503A. A. Laminated and bioturbated greenish black interval. Blue star = location of image in B. B. Thin section image of the greenish black interval with chlorite alteration. C. Alternating beds of light and dark gray nannofossil-rich claystone and nannofossilrich silty claystone with foraminifers dipping $\sim 30^{\circ}$. D. Millimeter-scale normal fault system in laminated siltstone.

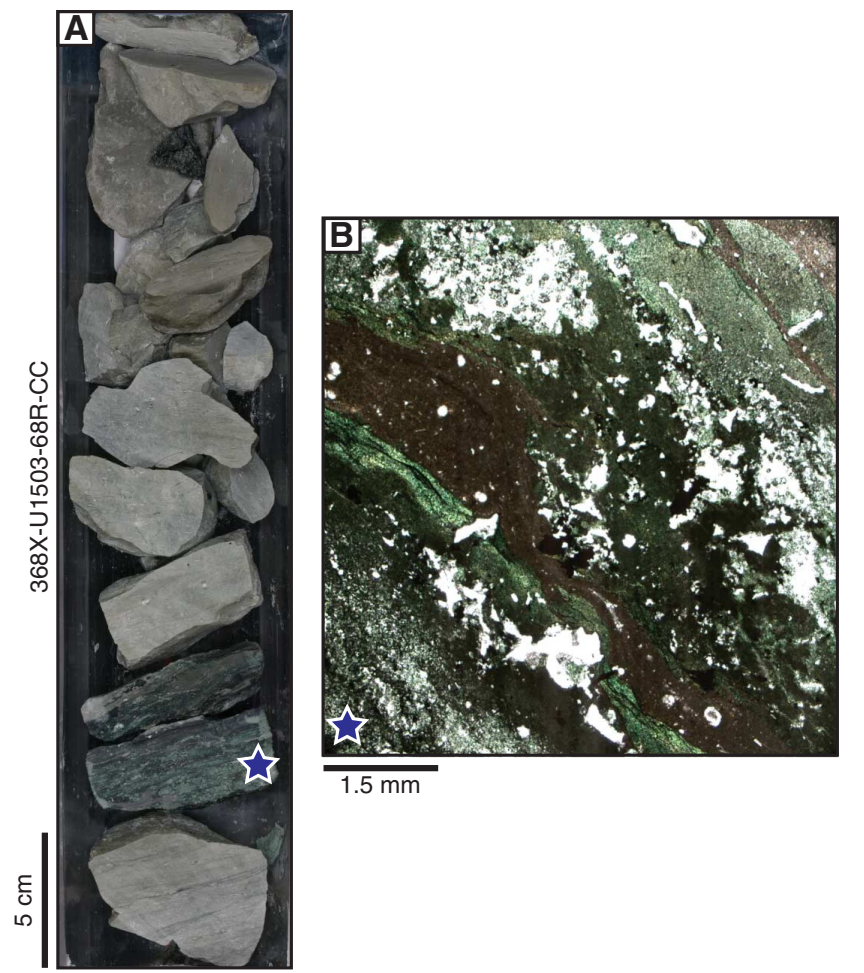

Igneous petrology and structural geology for description of principal composition). The basalt flows are bound with chilled, glassy margins plus occasional chert or claystone intervals (Samples 74R1, 49-61 cm; 79R-1, 5-23 cm; 81R-1; 114-122 cm; and 81R-2, 87$90 \mathrm{~cm}$ ). Claystone pieces recovered at the top of some cores are inferred to represent fall-in material.

\section{Igneous petrology and structural geology}

In Hole U1503A, basalt was drilled from 1597.84 to $1710.10 \mathrm{~m}$ with a total recovered core length of $47.51 \mathrm{~m}$. The basalts are sparsely to moderately plagioclase ( \pm olivine) phyric, nonvesicular to moderately vesicular with mostly subophitic, intergranular or interstitial textures. Lithostratigraphic Unit IV is composed of basalt and corresponds to igneous lithologic Unit 1. Igneous Unit 1 contains 38 hypohyaline to holohyaline chilled margins with altered glass, plus occasional chert, hyaloclastite, or claystone intervals. Igneous Unit 1 is further divided into three subunits (1a, 1b, and 1c) based on flow morphology and XRF compositional data: an upper sequence of pillow and lobate flows (Subunit 1a), a distinct massive flow (Subunit 1b), and a lower sequence of interbedded pillow, lobate, sheet, and massive flows (Subunit 1c). The highly plagioclasephyric horizons found at Sites U1500 and U1502 (see the Site U1500 chapter and the Site U1502 chapter [Stock et al., 2018; Larsen et al., 2018a]) were not observed in Hole U1503A, where modal phenocryst abundances are $<10 \%$. Veins are found throughout the lava flows as single, branched, or networks, in sharp contact with the host basalt, and are predominantly filled with carbonates, chlorite, pyrite, and Fe (hydr)oxides. Alteration of basaltic flows is slight to moderate throughout Unit IV.
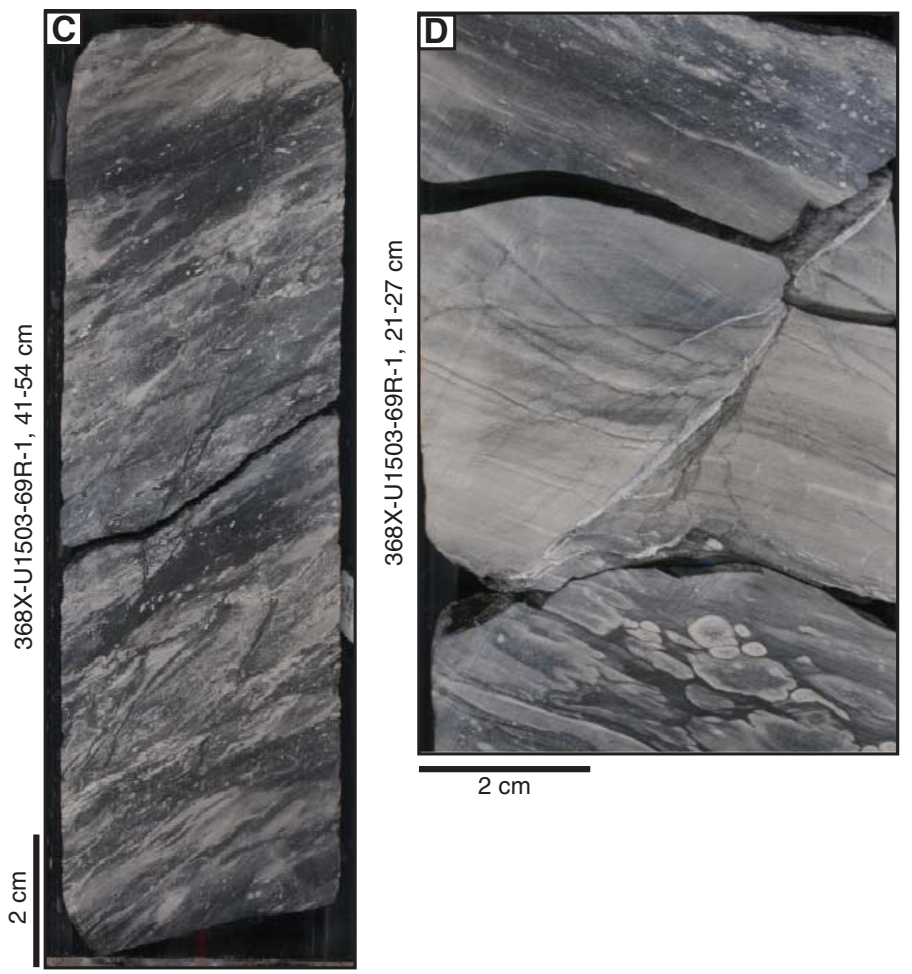

\section{Unit description \\ Igneous Unit 1 (lithostratigraphic Unit IV)}

Interval: 368X-U1503A-69R-2, $96 \mathrm{~cm}$, to $88 \mathrm{R}-4,130 \mathrm{~cm}$

Depth: $1597.84-1710.10 \mathrm{~m}$

Recovery: $47 \%$

Lithology: pillow and lobate flows of aphyric to plagioclase(-olivine) phyric basalt, with minor chert and claystone

Age: early Oligocene (older than 29-30 Ma)

The boundary between the sediment of lithostratigraphic Unit III and the underlying basalt of igneous Unit 1 is at $1597.84 \mathrm{~m}$. Igneous Unit 1 continues through $112.26 \mathrm{~m}$ of basement to $1710.1 \mathrm{~m}$ at the bottom of Hole U1503A. Unlike at Site U1500 (see the Site U1500 chapter [Stock et al., 2018]), the top of the basement is not well recovered. The sediment/basement contact occurs at the bottom of Section 368X-U1503A-69R-2 and is defined by the separation of claystone and basalt rubble. However, a chilled margin was observed in the basalt rubble. Throughout igneous Unit 1 , the recovered basaltic rocks remain mineralogically and texturally very similar (Figure F15D). Unit 1 is primarily composed of aphyric or sparsely to moderately plagioclase ( \pm olivine) phyric basalt that is nonvesicular to moderately vesicular (Figure F15C). Some pieces have an aphanitic or aphyric texture, but most textures were defined as subophitic, intergranular, or interstitial. Unit 1 contains 38 hypohyaline to holohyaline chilled margins with occasionally preserved altered glass (Figure F15A). The distribution of chilled margins is not homogeneous; the density of chilled margins is higher in the shallower cores (down to Core 368X-U1503A-78R) and in Core $87 \mathrm{R}$. The claystones are baked and crosscut by calcite and pyrite veins, indicating that they were emplaced before or during the extrusion of the basaltic melt. Unaltered claystone pieces together 
Figure F15. Macroscopic features in igneous lithologic Unit 1, Hole U1503A. A. Moderately plagioclase (Plg)-olivine (OI) phyric basalt with an altered glassy chilled margin. B. Baked blueish gray chert with some glass residue on its side. C. Macroscopic vesicles filled by recrystallized carbonate (CalV) and zeolite (ZV). D. Sparsely Plg phyric basalt with porphyritic texture (most common macroscopic texture observed throughout lithostratigraphic Unit IV). E. Vein with angular basalt fragments in calcite cement. F. Composite vein network with vuggy texture and carbonate (Cal), Fe oxide (FeO) and pyrite (Py) infill.

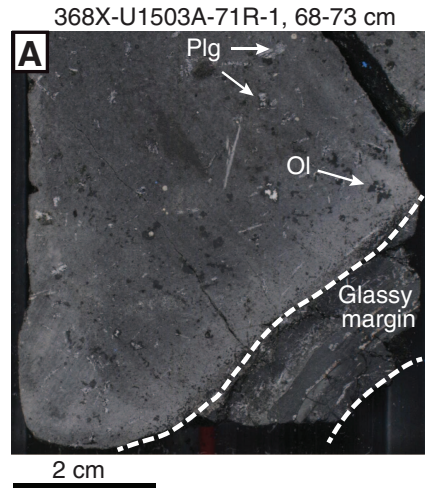

368X-U1503A-80R-1, 101-107 cm

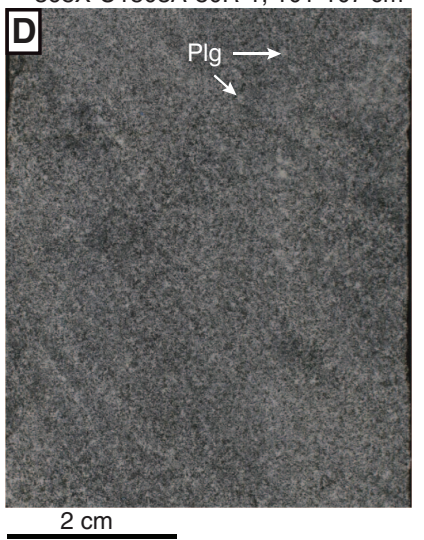

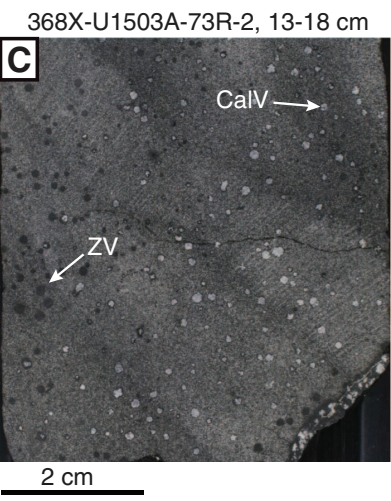

368X-U1503A-82R-1, 51-56 cm

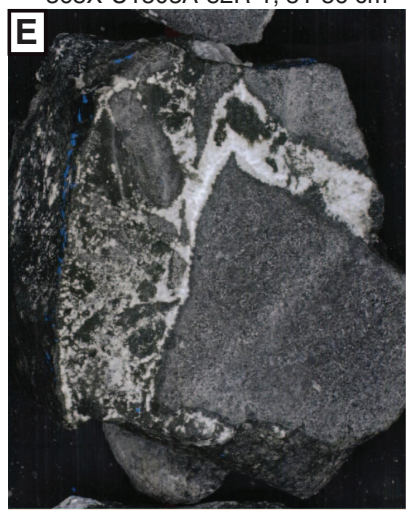

$2 \mathrm{~cm}$
368X-U1503A-78R-2, 77-84 cm

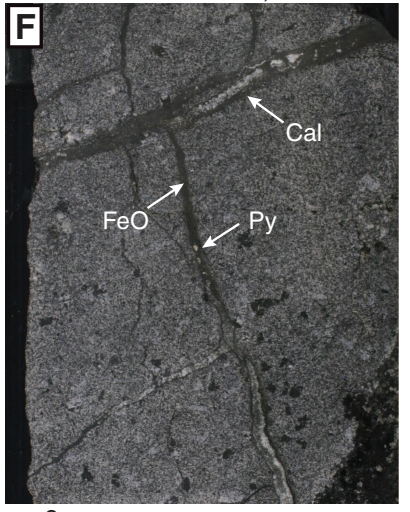

$2 \mathrm{~cm}$ with basalt fragments with a lithology different to the bulk of the core were recovered at the top of some cores and are inferred to represent fall-in pieces.

All recovered basalts are grouped as lithostratigraphic Unit IV (see Lithostratigraphy)/igneous Unit 1 due to the lack of any substantial change in mineralogy, texture, composition, or emplacement mechanism. The basalts are separated into three igneous lithologic subunits (1a, 1b, and 1c) based on flow morphology (Figure F16) and high-resolution, qualitative to semiquantitative compositional data obtained from XRF core scanning (Figure F17). Subunit 1a (50.0 m) is composed of $\sim 36$ pillow or lobate flows with intermediate to high Zr XRF intensities (Figure F16; Table T3). Subunit $1 \mathrm{~b}$ represents the first massive flow $(7.7 \mathrm{~m})$ and has a comparatively low $\mathrm{Zr}$ XRF intensity. The lower part of the volcanic sequence (i.e., Subunit 1c, $42.7 \mathrm{~m}$ thick) has alternations of pillow, lobate, sheet, and massive flows with mostly low Zr XRF intensities except for two horizons with high $\mathrm{Zr}$ XRF intensities (the base of Section 368X-U1503A-80R-2 to the top of Section 81R-1 and the base of Section $85 R-1$ to the top of Section $85 R-2$ ) that point to higher $\mathrm{Zr}$ contents compared to the other lava flow sequences.

The basalts are very dark gray to greenish gray, suggesting slight to moderate alteration. Euhedral fresh to completely replaced plagioclase phenocrysts were observed throughout the igneous Unit 1 basalts, and altered olivine and traces of altered clinopyroxene intermittently were found as sparse phenocryst phases. At the microscopic scale, the cryptocrystalline, hypocrystalline to fine-grained, porphyritic basalts show well-preserved primary igneous mineral assemblages (plagioclase, clinopyroxene, olivine, and Fe-Ti oxides) and microtextures ([sub]ophitic, aphanitic, intergranular, and interstitial) (Figure F18A-F18C). Elongated prismatic subhedral to euhedral plagioclase is the dominant phenocryst mineral $(1 \%-9 \%$; $0.5-10 \mathrm{~mm}$ ). Plagioclase glomerocrysts were occasionally observed in thin section. A small quantity of clinopyroxene phenocryst pseudomorphs $(<5 \%)$ were observed under the microscope, some of which are altered to amphibole, chlorite, and Fe-Ti oxide. Olivine $(<5 \% ; 0.1-0.3 \mathrm{~mm})$ remains an occasional phenocryst mineral throughout Unit 1 and is either fresh (Figure F18D) or recognizable by olivine pseudomorphs.

The hypocrystalline groundmass is primarily composed of plagioclase, clinopyroxene, glass, and Fe-Ti oxides and occasionally contains olivines that have been completely altered into serpentine. Plagioclase mostly occurs as narrow elongated prismatic or tabular crystals in subophitic relationships with clinopyroxene and altered glass. Clinopyroxene mostly occurs as narrow prismatic crystals within poikilitic texture or as interstitial stubby crystals between plagioclase laths. Clinopyroxene is partially slightly altered to chlorite and amphibole.

\section{Veins and alteration}

Veins are found throughout igneous Unit 1 and are predominantly filled with Fe hydr(oxides), carbonates, chlorite, and pyrite, giving them a black, greenish black, greenish white, or white to yellowish color. Veins mostly have a sharp contact with the host basalt and are single, in network, or sporadically branched (Figures F15F, 
Figure F16. Lithostratigraphic summary of igneous lithologic Unit 1 basalts showing lithology, lava flow type, and Subunits 1a-1d, Hole U1503A. So-called XRF groups based on Zr intensities obtained from XRF core scanning (see Figure F17) are shown. The classification of subunits is primarily based on the predominant lava flow type, which may be coincident with a change in chemical composition reflected by the XRF data.

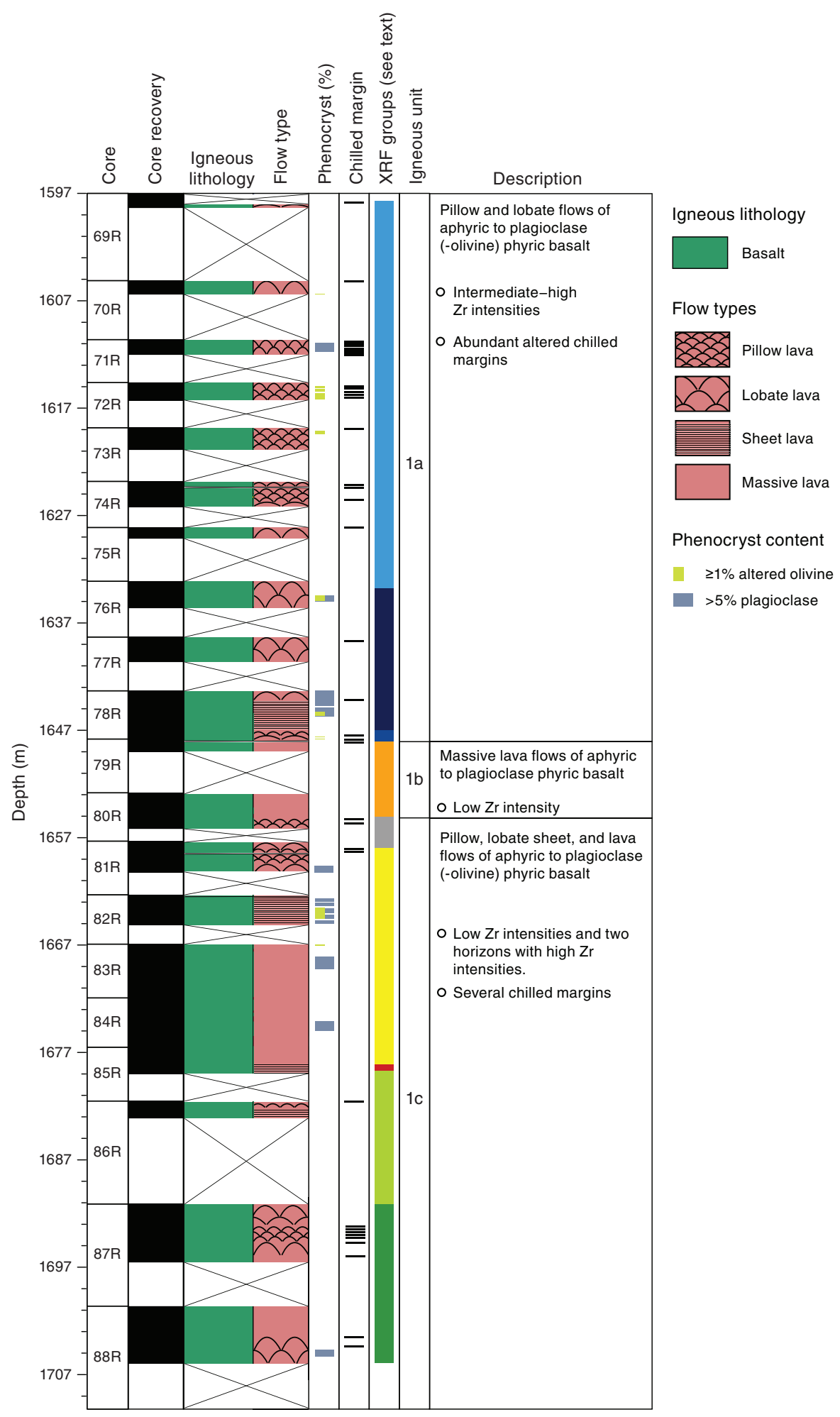

F18E). No preferred orientation or dip of veins can be determined from the whole-round images and structural measurements. Vein texture is often either vuggy with mixed mineralogy or massive. In places, veins have a brecciated appearance with angular basalt clasts surrounded by recrystallized calcite (Figure F15E). Red alteration halos were only observed in the deepest recovered intervals (Cores 368X-U1503A-87R and 88R), which contrasts with the observations at Site U1500, where such halos are ubiquitous (see the Site U1500 
Figure F17. XRF basalt geochemical proxies, Sections 368X-U1503A-70R-1 through 88R-4. The three igneous Subunits 1a, 1b, and 1c are divided into 3, 1, and 4 distinct XRF groups, respectively. See text for more explanation. A. Zr enrichment factor, defined as the ratio of Zr peak area total counts of a given sample to the average Zr peak area counts of the combined low-Zr orange + yellow + green XRF groups. B. Ti intensity in peak area total counts. C. Ti/Zr values.

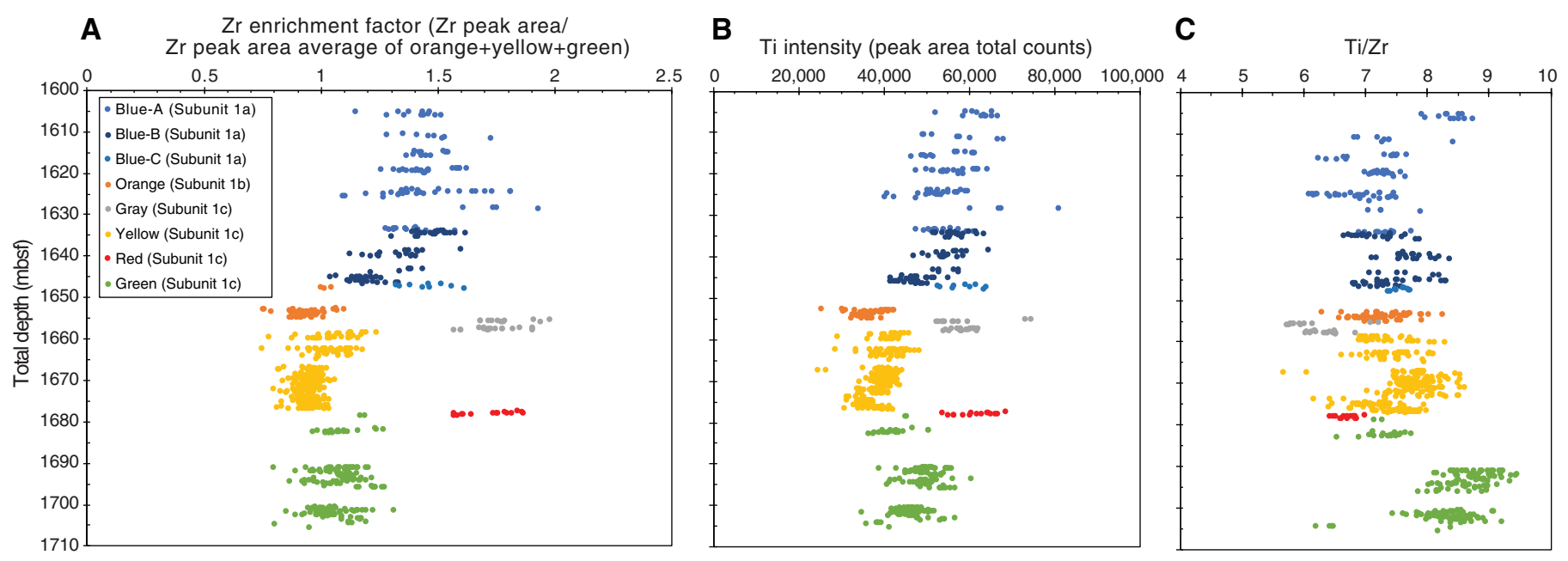

Table T3. Discrete lava sequences, Hole U1503A. Sequences are characterized by associated flow types that have been chemically grouped based on X-ray fluorescence (XRF) data (see Figure F17). Download table in CSV format.

\begin{tabular}{|c|c|c|c|c|c|c|c|}
\hline \multicolumn{2}{|c|}{$\begin{array}{l}\text { Core, section, } \\
\text { interval }(\mathrm{cm})\end{array}$} & \multirow{2}{*}{$\begin{array}{l}\text { Top } \\
\text { depth } \\
\text { (mbsf) }\end{array}$} & \multirow{2}{*}{$\begin{array}{l}\text { Total } \\
\text { thickness } \\
\text { (m) }\end{array}$} & \multirow[b]{2}{*}{ Lava flow type } & \multirow{2}{*}{$\begin{array}{l}\text { Number } \\
\text { of flows }\end{array}$} & \multirow{2}{*}{$\begin{array}{c}\text { XRF } \\
\text { Chemical } \\
\text { Group }\end{array}$} & \multirow[b]{2}{*}{ Subunit } \\
\hline From & To & & & & & & \\
\hline 368X-U1503A- & 368X-U1503A- & & & & & & \\
\hline $69 \mathrm{R}-2,96$ & $76 \mathrm{R}-1,96$ & 1597.8 & 36.1 & Lobate/Pillows & $\sim 27$ & Blue-A & $1 \mathrm{a}$ \\
\hline 76R-1, 96 & $78 \mathrm{R}-3,72$ & 1634.0 & 12.8 & Lobate & $\sim 7$ & Blue-B & $1 a$ \\
\hline $78 R-3,72$ & $78 R-4,60$ & 1646.8 & 1.1 & Lobate/Pillow & 2 & Blue-C & $1 a$ \\
\hline $79 \mathrm{R}-1,25$ & $80 \mathrm{R}-2,114$ & 1647.5 & 7.7 & Massive & 1 & Orange & $1 \mathrm{~b}$ \\
\hline $80 R-2,114$ & $81 \mathrm{R}-1,95$ & 1655.2 & 3.0 & Lobate/Pillows & 4 & Gray & $1 \mathrm{c}$ \\
\hline $81 \mathrm{R}-1,95$ & $82 \mathrm{R}-1,23$ & 1658.2 & 4.3 & Lobate/Pillows & $\sim 6$ & Yellow & $1 \mathrm{c}$ \\
\hline $82 \mathrm{R}-1,23$ & $85 \mathrm{R}-1,76$ & 1662.4 & 14.7 & Massive/Sheet & $\sim 4$ & Yellow & 1c \\
\hline $85 \mathrm{R}-1,76$ & $85 R-2,68$ & 1677.2 & 1.3 & Pillow/Sheet & 2 & Red & $1 c$ \\
\hline $85 \mathrm{R}-2,68$ & $86 \mathrm{R}-2,52$ & 1678.5 & 4.6 & Sheet & 3 & Green-A & $1 c$ \\
\hline $87 \mathrm{R}-1,0$ & $87 \mathrm{R}-4,75$ & 1691.0 & 5.1 & Lobate/Pillows & $\sim 8$ & Green-B & $1 \mathrm{c}$ \\
\hline $87 \mathrm{R}-4,75$ & $88 \mathrm{R}-2,125$ & 1696.1 & 6.8 & Massive & 1 & Green-B & $1 \mathrm{c}$ \\
\hline \multirow[t]{2}{*}{$88 \mathrm{R}-2,125$} & $88 R-4,130$ & 1702.9 & 2.9 & Lobate & 3 & Green-B & $1 \mathrm{c}$ \\
\hline & & Total: & 100.4 & & $\sim 68$ & & \\
\hline
\end{tabular}

chapter [Stock et al., 2018]). Background alteration varies from slight to moderate in intensity throughout Unit 1 with no systematic variation downhole. Vesicles in the flows are generally moderately to highly spherical and rounded and filled with black Fe (hydr)oxides, dark green zeolites, chlorite, and carbonates and occasional pyrite (Figure F18F). The intensity of alteration of the Unit 1 basalts is generally higher than the Site U1500 basalts (see the Site U1500 chapter [Stock et al., 2018]), although nowhere near as high as the Site U1502 basalts (see the Site U1502 chapter [Larsen et al., 2018a]). Preservation of plagioclase phenocrysts varies from fresh to completely altered and pseudomorphed by dark green zeolite or chlorite. Olivine and clinopyroxene phenocrysts are mostly completely altered and replaced by serpentine or iddingsite, and no fresh glass is preserved in chilled margins.

\section{Bulk mineralogy}

There are five XRD samples from igneous Unit 1 taken from between 1598.1 and 1656.0 mbsf (see XRD in Supplementary material [Sun et al., 2018b]). The uppermost XRD sample is dominated by plagioclase $(58.1 \%)$ with a labradorite composition $(50 \%-70 \%$ anorthite component) and secondary minerals of mainly smectite and serpentine groups (combined 40\%). This reflects the moderate to high alteration with no fresh clinopyroxene present. Samples taken farther downhole reveal less alteration; minerals of the smectite group range from $\sim 17 \%$ to $30 \%$. Also, they contain a significant primary clinopyroxene component that has been identified as augite $(\sim 24 \%-32 \%)$. The labradorite content ranges from $\sim 47 \%$ to $52 \%$ in these deeper samples. They also contain subordinate ilmenite $(\sim 1 \%-2 \%)$. The XRD data are consistent with a small variation in basaltic modal composition observed visually.

\section{Chemical composition (pXRF and XRF core scanning)}

Compositional analyses of igneous Unit 1 basalts, as well as veins and clasts, were made directly on the archive half of the core using the handheld pXRF (see Igneous and metamorphic petrology in the Expedition 367/368 methods chapter [Sun et al., 2018a]). The average pXRF sample spacing was about every $20 \mathrm{~cm}$ for the 
Figure F18. Microscopic features in igneous lithologic Unit 1, Hole U1503A. A. Hypocrystalline texture with Plg and Cpx microphenocrysts. Cpx is altered to amphibole (72R-1; TS03). Plg = plagioclase, $\mathrm{Cpx}=$ clinopyroxene. B. Ophitic texture with some Plg phenocryst and Plg, Cpx, and Ol constituting the groundmass (73R-2; TS04). OI = olivine. C. Plg phenocryst (73R-2; TS04). D. Close-up of Ol and Cpx (73R-2; TS04). E. Calcite vein crosscutting basalt with intergranular texture (76R-2; TS05). F. Vesicle (Vsl) and vein filled by calcite (Cal) and FeO with zeolite (Z) on the rim (76R-2; TS05).

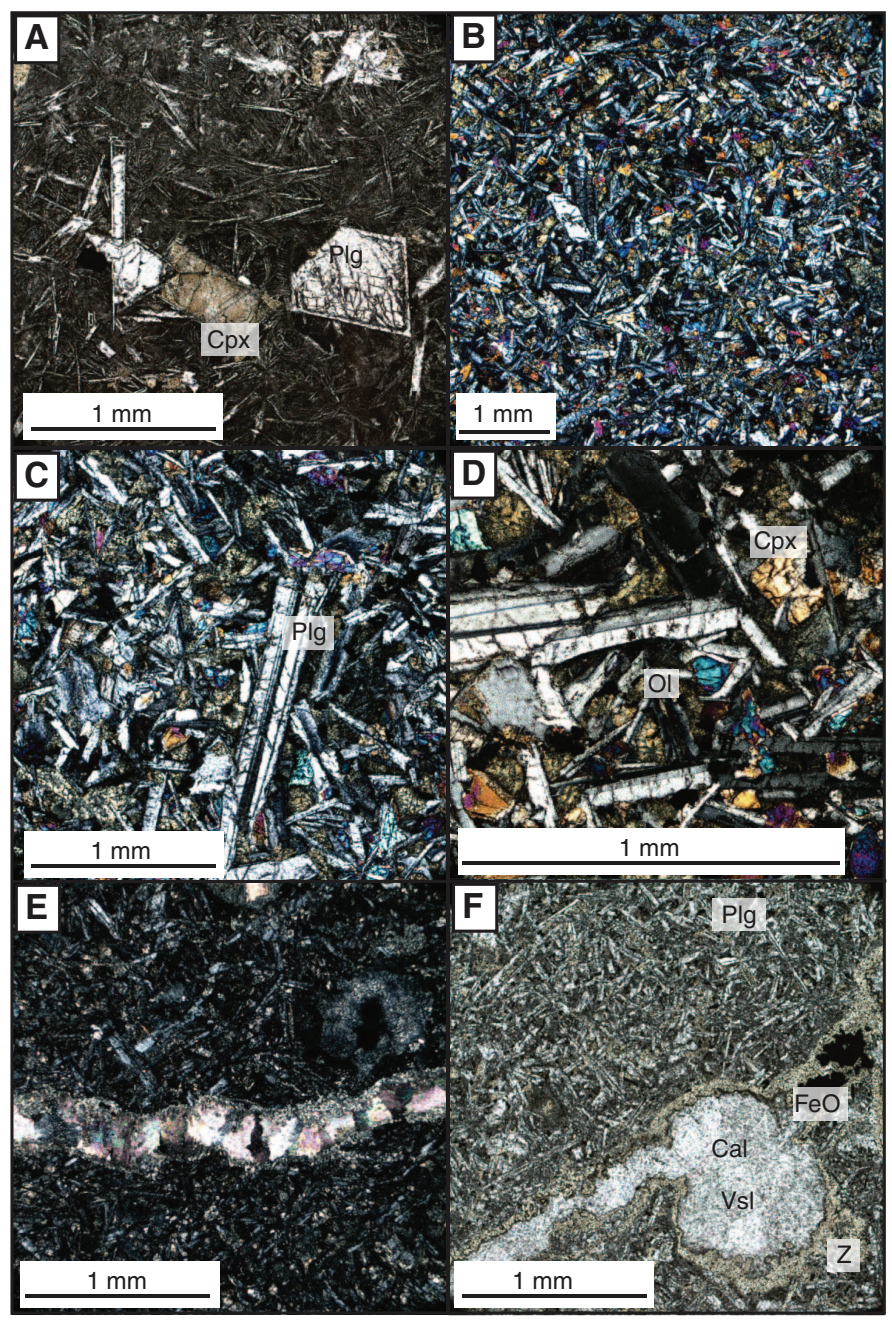

upper cores (368X-U1503A-70R through 80R) and one per core section for the lower cores (81R through $88 \mathrm{R})$. The raw, unprocessed pXRF data can be retrieved as shipboard data from the IODP Laboratory Information Management System (LIMS) database (http://web.iodp.tamu.edu/LORE). The pXRF data for the Hole U1503A basalts show significant variability in incompatible elements:

- $\mathrm{TiO}_{2}=1.2-2.2 \mathrm{wt} \%$ (average $\left.=1.6 \pm 0.2 \mathrm{wt} \%\right)$.

- $\mathrm{Zr}=80-175 \mathrm{ppm}$ (average $=124 \pm 21 \mathrm{ppm})$.

- $\mathrm{Sr}=170-290 \mathrm{ppm}($ average $=233 \pm 25 \mathrm{ppm})$.

These data overlap with compositions measured by pXRF on the Site U1500 basalts $\left(\mathrm{TiO}_{2}=1.5 \pm 0.1 \mathrm{wt} \%, \mathrm{Zr}=97 \pm 10 \mathrm{ppm}\right.$, and $\mathrm{Sr}$ = $161 \pm 17$ ppm; see the Site U1500 chapter [Stock et al., 2018]) but extend to higher values. Ratios of immobile incompatible elements such as $\mathrm{Ti} / \mathrm{Zr}$ also show a greater range compared to those for Site $\mathrm{U} 1500(\mathrm{Ti} / \mathrm{Zr}=64-110$ versus $84-107)$.
Systematic downhole compositional variations are clearly shown in the high-resolution XRF core scanning data set that was produced onshore for the Site U1503 basalts (see Igneous and metamorphic petrology in the Expedition 367/368 methods chapter [Sun et al., 2018a]). These data were acquired at a $2 \mathrm{~cm}$ spacing and can be retrieved as shipboard data from the LIMS database. Based on measured element intensities (in peak area total counts), the downhole variation of incompatible high field strength elements (e.g., Ti and Zr) reveals six major geochemical groups (Figure F17), each composed of one to several lava flows of different morphological types (Figure F16). These types are distinguished by changes in relative $\mathrm{Zr}$ intensities (Figure F17A), Ti peak intensities (Figure F17B), and Ti/Zr (Figure F17C) values that demonstrate varying compositional enrichments among lava sequences and thus suggest melt differentiation trends. The upper part of the recovered basalts (the base of Section 368X-U1503A-69R-2 through the base of Section 78R-4) shows an intermediate $\mathrm{Zr}$ enrichment (blue circles in Figure F17; Figure F16) compared to the low-Zr intensities that predominate from Section 79R-1 to the bottom of the hole (Figure F17). Morphologically, the intermediate- $\mathrm{Zr}$ group is made up of the igneous lithologic Subunit 1a lobate and pillow flows (50 m thick) that show an overall bottom-to-top increase in Ti intensities. This "blue group," however, also reveals internal Ti variation that leads to distinction of three subgroups (Figure F17B). The uppermost lobate/pillow lava Subunit 1a is underlain by a low-Zr-Ti massive flow ( $\sim 8 \mathrm{~m}$ thick; from Section 79R-1, $25 \mathrm{~cm}$, to Section 80R-2, 114 cm) that constitutes Subunit 1b (orange circles in Figure F17A) and also shows an uphole increase of Ti peak intensities (Figure F17B). Further downhole, two high-Zr-Ti lava flow sequences ("gray group" lobate/pillows from Section 80R-2, $114 \mathrm{~cm}$, to Section 81R-1, $95 \mathrm{~cm}$, and "red group" sheet/pillows from Section 85R-1, $76 \mathrm{~cm}$, to Section $85 \mathrm{R}-2,68 \mathrm{~cm}$ ) are separated by a much thicker low-Zr-Ti flow sequence consisting of massive and sheet flows $(\sim 15 \mathrm{~m})$ and capping lobate and pillow pillows ( $\sim 4 \mathrm{~m}$; yellow circles in Figure F17). The lowermost high-Zr-Ti group (red circles in Figure F17) is underlain by another distinct group of low-Zr-Ti intensities (green circles in Figure F17) represented by interbedded massive/sheet and lobate/pillow flows that were recovered from Section 85R-2, $68 \mathrm{~cm}$, to the bottom of Hole U1503A ( $19 \mathrm{~m}$ in total). In this "green group," the uppermost sheet/pillow flows (downhole to Section 86R-2, 52 $\mathrm{cm}$ ) reveal similar $\mathrm{Zr}$ but lower $\mathrm{Ti}$ intensities compared with the flows below, leading to distinctly lower $\mathrm{Ti} / \mathrm{Zr}$ values (light green circles in Figure F17C) that are more akin to the "yellow group." Similar to the latter, the lowermost lava flows of Hole U1503A (dark green circles in Figure F17) show an overall increase of Ti intensities from the bottom of the sequence to the top (Figure F17B). Table T3 shows an overview of the intervals and thicknesses of lava sequences and associated flow types that are divided into the XRF data groups.

\section{Interpretation}

The minimum age for the igneous lithologic Unit 1 basalts is constrained by microfossil data for the immediately overlying sediments (lithostratigraphic Unit III) in Section 368X-U1503A-69R-2$\mathrm{CC}$, which provide an age of 29-30 Ma (early Oligocene).

The flow morphologies and presence of chilled margins and pillow-like structures suggest emplacement of the basalts as subaqueous eruptions in approximately 68 individual lava flows. These can be reconciled in distinct chemical groups, forming separate lava flow sequences that internally reveal melt fractionation trends. The basalts show a typical mid-ocean-ridge basalt (MORB) mineralogy dominated by plagioclase phenocrysts and occasional subordinate 
olivine phenocrysts. The broad compositional similarity to the Site U1500 basalts shown by the XRF data is also consistent with a MORB-like affinity.

\section{Biostratigraphy}

Core catcher samples from Hole U1503A were analyzed for calcareous nannofossils and planktonic foraminifers. Additional samples were taken from intervals in the cores when necessary to refine the ages. Calcareous nannofossils are barren or rare in most samples, especially in red clay sediments, but are abundant or common in some turbidite or chalk samples. Varying degrees of overgrowth and broken fragments are common on nannofossils. In most parts of the sediments, planktonic foraminifers are barren and moderate to poorly preserved.

Nine biostratigraphic datums were used to provide an age-depth model for Site U1503 from the early Oligocene to the middle Miocene (Tables T4, T5; Figure F19). The early/late Oligocene boundary was placed tentatively between Cores 368X-U1503A-60R and $65 \mathrm{R}$. The early/middle Miocene boundary was determined to occur between Cores 53R and -54R. Sedimentation rates varied from $\sim 7$ $\mathrm{mm} / \mathrm{ky}$ during the Oligocene and early Miocene to $\sim 60 \mathrm{~mm} / \mathrm{ky}$ in the middle-late Miocene.

Deepwater agglutinated benthic foraminifers were found in Samples 368X-U1503A-26R-CC to 65R-CC, indicating an abyssal paleoenvironment.

\section{Calcareous nannofossils}

Calcareous nannofossil biostratigraphy at Site U1503 is based on analysis of 30 core catcher samples and 26 section-half samples from Hole U1503A (Tables T4, T6). Calcareous nannofossil zonation was based on the scheme of Martini (1971), and the calibrated ages for bioevents are from Gradstein et al. (2012). Calcareous nannofossil abundances vary abruptly in the succession; they are barren or rare in most samples, especially in red clay, and common to abundant in some turbidite or chalk samples. In general, nannofossil preservation and assemblage composition is variably affected by carbonate dissolution and the presence of turbidites. Varying degrees of overgrowth, reworked specimens, and abundant broken fragments on nannofossils are common, especially among the discoasters.

Five nannofossil biostratigraphic datums were recognized from the Oligocene to the middle Miocene sediment sequence (Table T4). The oldest nannofossil event identified is the last appearance datum (LAD) of Sphenolithus pseudoradians, which occurs at $1579.95 \mathrm{~m}$, indicating an age $>28.73 \mathrm{Ma}$ for the bottom part of the sedimentary sequence at Site U1503.

\section{Miocene}

Three events occur in the Miocene strata in Hole U1503A (Table T4). The LAD of Cyclicargolithus floridanus (11.85 Ma) marks the top of Zone NN6 in Sample 368X-U1503A-4R-1A, $61 \mathrm{~cm}$ (1010.81 m), which corresponds to the top of the middle Miocene. The first appearance datum (FAD) of Reticulofenestra pseudoumbilicus (12.83 Ma) occurs in Sample 28R-CC (1242.86 m), which is also in Zone NN6. The FAD of Sphenolithus heteromorphus (17.71 Ma) occurs in Sample 53R-2, $103 \mathrm{~cm}$ (1482.64 m), which is at the bottom of Zone NN4, indicating an early Miocene age.

\section{Oligocene}

From Section 368X-U1503A-59R-CC through interval 69R-2, 78-96 cm, the early-late Oligocene assemblages composed of Sphenolithus ciperoensis, Sphenolithus predistentus?, Sphenolithus distentus?, Sphenolithus pseudoradians, and Reticulofenestra bisecta $(>10 \mu \mathrm{m})$ were observed. The LAD of S. distentus (26.84 Ma), which marks the top of Zone NP24, was found in Sample 60R-CC $(1538.35 \mathrm{~m})$. The LAD of S. pseudoradians $(28.73 \mathrm{Ma})$ in Zone NP24 was found in Sample 69R-2, 78-96 cm (1597.84 m). S. distentus was found in Sample 69R-2, 78-96 cm, at $1597.84 \mathrm{~m}$. Because the age of the FAD of $S$. distentus is $30 \mathrm{Ma}$, the age of the basal sediments in Hole U1503A is younger than $30 \mathrm{Ma}$.

Table T4. Calcareous nannofossil biostratigraphic events, Hole U1503A. T = top/last appearance datum, B = bottom/first appearance datum. Download table in CSV format.

\begin{tabular}{|c|c|c|c|c|c|c|c|c|}
\hline \multirow[b]{2}{*}{ Epoch } & \multirow[b]{2}{*}{$\begin{array}{c}\text { Biozones } \\
\text { (Martini, 1971) }\end{array}$} & \multirow[b]{2}{*}{ Calcareous nannofossil events } & \multicolumn{2}{|c|}{ Top depth } & \multicolumn{2}{|c|}{ Bottom depth } & \multicolumn{2}{|c|}{ Age model } \\
\hline & & & $\begin{array}{l}\text { Core, section, } \\
\text { interval }(\mathrm{cm})\end{array}$ & CSF-A (m) & $\begin{array}{l}\text { Core, section, } \\
\text { interval }(\mathrm{cm})\end{array}$ & CSF-A (m) & $\begin{array}{l}\text { Midpoint } \\
\text { depth }(m)\end{array}$ & $\begin{array}{l}\text { Age } \\
\text { (Ma) }\end{array}$ \\
\hline \multirow{3}{*}{ middle Miocene } & \multirow{3}{*}{ NN6 } & & $368 X-U 1503 A-$ & & $368 X-U 1503 A-$ & & & \\
\hline & & T Cyclicargolithus floridanus & $4 \mathrm{R}-1 \mathrm{~A}, 37$ & 1010.57 & $4 \mathrm{R}-1 \mathrm{~A}, 61$ & 1010.81 & 1010.69 & 11.85 \\
\hline & & B Reticulofenestra pseudoumbilicus & $28 \mathrm{R}-\mathrm{CC}$ & 1242.86 & 30R-CC & 1260.38 & 1251.62 & 12.83 \\
\hline early Miocene & NN4 & B Sphenolithus heteromorphus & 53R-2A, 103 & 1482.64 & 54R-1A, 110 & 1490.8 & 1486.72 & 17.71 \\
\hline late Oligocene & NP24 & T Sphenolithus distentus & 59R-CC & 1533.67 & 60R-CC & 1538.35 & 1536.01 & 26.84 \\
\hline early Oligocene & NP24 & T Sphenolithus pseudoradians & $65 \mathrm{R}-\mathrm{CC}$ & 1562.06 & 69R-2W, 78-96 & 1597.84 & 1579.95 & 28.73 \\
\hline
\end{tabular}

Table T5. Planktonic foraminiferal biostratigraphic events, Hole U1503A. $\mathrm{T}=$ top/last appearance datum, $\mathrm{Br}=$ base/first regular appearance datum. Download table in CSV format.

\begin{tabular}{|c|c|c|c|c|c|c|c|c|}
\hline \multirow[b]{3}{*}{ Epoch } & \multirow{3}{*}{$\begin{array}{c}\text { Biozone } \\
\text { (Blow, 1969) }\end{array}$} & \multirow[b]{3}{*}{ Events } & \multirow{2}{*}{\multicolumn{2}{|c|}{ Top depth }} & \multirow{2}{*}{\multicolumn{2}{|c|}{ Bottom depth }} & \multicolumn{2}{|c|}{ Age model } \\
\hline & & & & & & & \multirow{2}{*}{$\begin{array}{l}\text { Midpoint } \\
\text { depth (m) }\end{array}$} & \multirow{2}{*}{$\begin{array}{l}\text { Age } \\
\text { (Ma) }\end{array}$} \\
\hline & & & Core, section & $\mathrm{CSF}-\mathrm{A}(\mathrm{m})$ & Core, section & CSF-A (m) & & \\
\hline \multirow{3}{*}{ late Miocene } & \multirow{3}{*}{ N14 } & & $368 X-U 1503 A-$ & & 368X-U1503A- & & & \\
\hline & & T Paragloborotalia mayeri & & & 8R-CC & 1051.74 & 1051.74 & 10.46 \\
\hline & & Br Globigerinoides obliquus & 47R-CC & 1427.55 & 48R-CC & 1435.25 & 1431.40 & 11.25 \\
\hline early Miocene & N5 & T Paragloborotalia nana & $55 \mathrm{R}-\mathrm{CC}$ & 1503.19 & 56R-CC & 1514.94 & 1509.07 & 19.30 \\
\hline late Oligocene & $\mathrm{P} 21$ & T Paragloborotalia opima & 60R-CC & 1538.35 & $65 \mathrm{R}-\mathrm{CC}$ & 1562.06 & 1550.21 & 26.93 \\
\hline
\end{tabular}


Figure F19. Age-depth plot, Hole U1503A. Details of each plotted event are given in Tables T4 and T5.

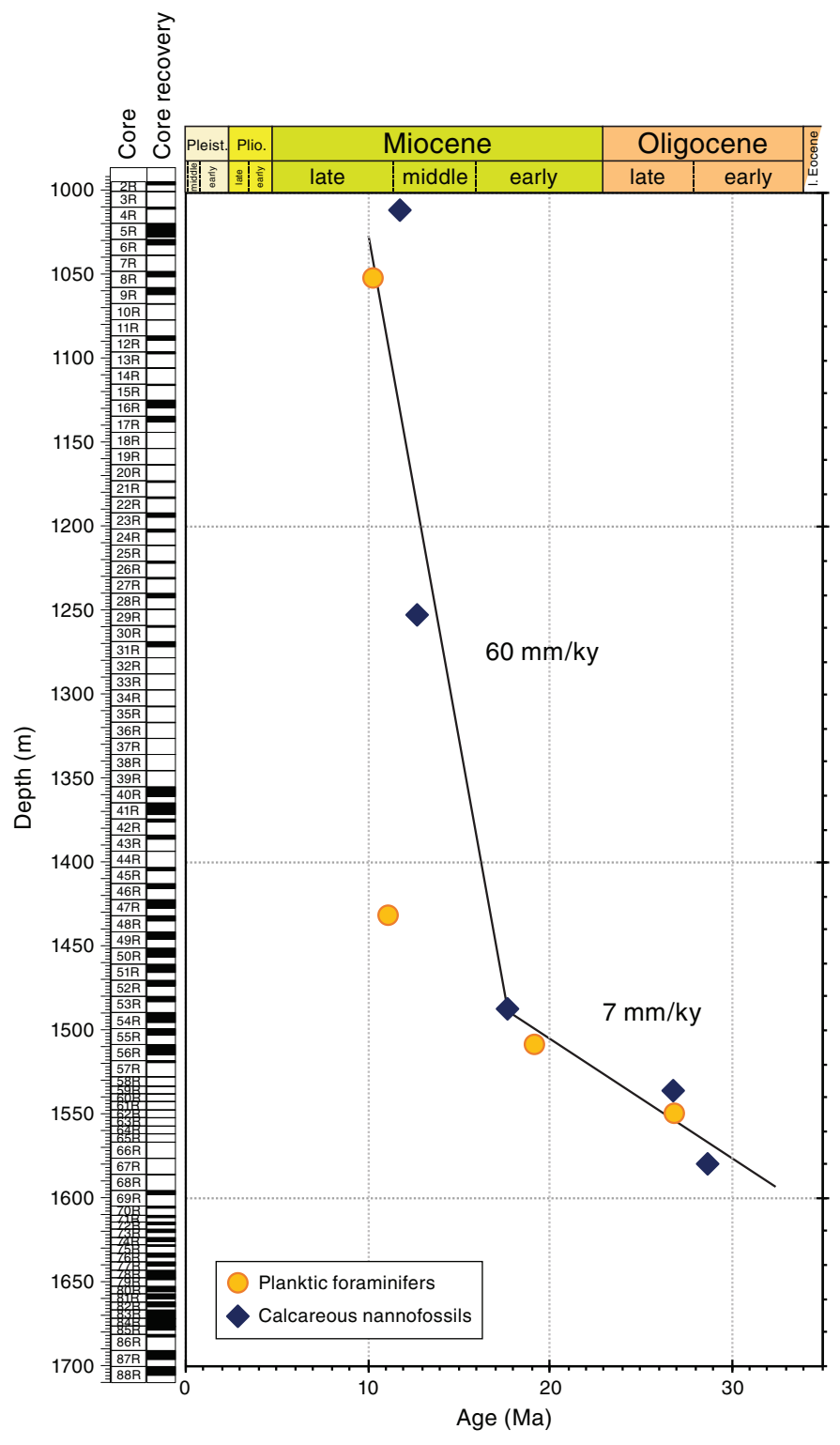

Table T6. Calcareous nannofossil distribution, Hole U1503A. Download table in CSV format.

Table T7. Planktonic foraminifer distribution, Hole U1503A. Download table in CSV format.

\section{Planktonic foraminifers}

Twenty-seven core catcher samples and three additional samples taken from the working half cores in Hole U1503A were processed for planktonic foraminiferal analyses (Table T7). Two-thirds of the samples were barren of planktonic foraminifers (e.g., Samples 368X-U1503A-2R-CC, 6R-CC, 9R-CC, 13R-CC to 21R-CC, 26R-CC to $40 \mathrm{R}-\mathrm{CC}, 48 \mathrm{R}-\mathrm{CC}$ to $55 \mathrm{R}-\mathrm{CC}$, and 69R-CC). Planktonic foraminifers are well to moderately preserved in the core catcher samples from Cores 5R, 8R, 12R, 23R through 25R, 41R, 47R, 56R, 60R, and $65 R$.
Four planktonic foraminiferal biostratigraphic datums were recognized in Hole U1503A spanning from the late Oligocene (Zone P21) to the late Miocene (Zone N14) (Table T5). One event was found in the Oligocene strata of Hole U1503A. The LAD of Paragloborotalia opima (26.98 Ma) occurs in Sample 368X-U1503A-65R$\mathrm{CC}(1562.06 \mathrm{~m})$ and provides a biostratigraphic control point for the boundary of Zones P21 and P22. The LAD of Paragloborotalia nana (19.3-21.12 Ma) in Sample 56R-CC (1514.94 m) marks the lower part of Zone N5. The FAD of regular Globigerinoides obliquus (11.25 Ma) in Zone N14 was found in Sample 47R-CC (1427.55 m). The LAD of Paragloborotalia mayeri was found in Sample 8R-CC (10.46 Ma; $1051.74 \mathrm{~m}$ ) and provides a biostratigraphic control point for the boundary of Zones N14 and N15.

The planktonic foraminiferal biostratigraphy for Hole U1503A was established by the above events and the planktonic foraminiferal assemblages at successive depth intervals. The Oligoceneearly Miocene planktonic foraminiferal assemblage in Cores 368XU1503A-56R through 65R is dominated by Catapsydrax dissimilis, P. nana, and Globigerina praebulloides. The middle-late Miocene planktonic foraminiferal assemblage in Cores $8 \mathrm{R}$ through $47 \mathrm{R}$ is dominated by G. obliquus, Globigerinoides triloba, P. mayeri, Dentoglobigerina altispira, and Orbulina universa, whereas Sphaeroidinellopsis seminulina occurs in Samples 25R-CC, 23R-CC, and 8RCC.

\section{Benthic foraminifers}

In Hole U1503A, neritic benthic foraminifers Ammonia and Florius were observed in some sandstone samples (e.g., 368XU1503A-8R-CC and 56R-CC), which suggests the influence of downslope transport from shallow water environments. Deepwater agglutinated benthic foraminifers (e.g., Glomospira, Trochamminopsis, Recurvoides, and Ammolagena) are common in Samples 26R$\mathrm{CC}$ to $65 \mathrm{R}-\mathrm{CC}$, indicating an abyssal paleoenvironment.

\section{Paleomagnetism Shipboard measurements}

Shipboard paleomagnetic investigations combined two complementary approaches (see the Expedition 367/368 methods chapter and Paleomagnetism in the Expedition 368X methods supplement chapter [Sun et al., 2018a; Childress et al., 2020]): (1) measurement and in-line alternating field (AF) demagnetization of archive-half sections on the pass-through 2G Enterprises superconducting rock magnetometer (SRM) at 2 or $2.5 \mathrm{~cm}$ spacing and (2) measurement and AF demagnetization of 62 oriented discrete samples on the AGICO JR-6A spinner magnetometer. In addition, the anisotropy of magnetic susceptibility (AMS) was measured on discrete samples with a KLY 4 Kappabridge (AGICO).

Depending on core recovery and lithology, usually only one discrete sample was collected from each core to perform AF demagnetization. We used the directional and intensity data of archive-half sections (measured at $25 \mathrm{mT}$ for sediments and $15 \mathrm{mT}$ for basalts) to determine magnetic polarity along the core. Directional and intensity data from discrete samples were used to validate the polarities inferred from section measurements. Directional data were analyzed using Zijderveld diagrams (Zijderveld, 1967). The characteristic remanent magnetization (ChRM) direction(s) were calculated using the Remasoft 3.0 software and plotted using the PuffinPlot software (version 1.03; 23 April 2015; Lurcock and Wilson, 2012). 


\section{Demagnetization behavior}

\section{Sediments}

The archive-half sections of sediment Cores 368X-U1503A-2R through 63R (995.1-1552.45 m), excluding cores with $<2 \%$ recovery (only the core catcher), were measured on the SRM at a $2.5 \mathrm{~cm}$ spacing. After measuring the natural remanent magnetization (NRM), the cores were subjected to a stepwise in-line AF demagnetization at $5,10,15,20$, and $25 \mathrm{mT}$. Between Sections 67R-CC and 69R-2 (1576.5-1597.38 m), the same AF demagnetization steps used for basement archive-half sections were applied. Lithostratigraphic Unit II, characterized by reddish claystone, has an average initial intensity of magnetization on the order of $10^{-2} \mathrm{~A} / \mathrm{m}$, which is higher than the average initial intensity of magnetization of the brownish, greenish, and gray sediments of Units I $\left(10^{-3} \mathrm{~A} / \mathrm{m}\right)$ and III $\left(10^{-4} \mathrm{~A} / \mathrm{m}\right)$.

A total of 43 discrete samples were collected from sediment cores (see Lithostratigraphy). Because of the low recovery rate, only four discrete samples were collected in lithostratigraphic Unit II and one discrete sample was collected in Unit III. The samples were AF demagnetized at 2.5, 5, 7.5, 10, 15, 20, 25, 30, 35, 40, 50, 60, 70 , and $80 \mathrm{mT}$ steps. Demagnetization axes were inverted at each step of demagnetization to minimize gyroremanent magnetization.

The discrete samples show two components of magnetization (Figure F20). A low-coercivity component of magnetization isolated in 15 of 43 discrete samples in a variable interval generally ranges from NRM (or $2.5 \mathrm{mT}$ ) to 7.5 (or 25) $\mathrm{mT}$. This component, which always shows a normal polarity and has a mean inclination of $41.8^{\circ} \pm 10.4^{\circ}$, is interpreted to be a drilling-induced overprint (e.g., Figure F20A, F20E). The ChRM shows two different behaviors and, depending on the presence and range of the low-coercivity one, can be isolated either between 2.5 (or 5) $\mathrm{mT}$ and 15 (up to 30 or 40) $\mathrm{mT}$ or between $5 \mathrm{mT}$ (or 7.5/30 $\mathrm{mT}$ when the low-coercivity component is detected) and to 50 (up to 80) $\mathrm{mT}$. The mean inclination of the ChRM is $26.4^{\circ} \pm 8.0^{\circ}$, which is close to the $25^{\circ}$ inclination expected at the latitude of Hole U1503A.

Some samples exhibit a coercivity inversion or plateau that suggests the presence of greigite (Figure F20C, F20G) (e.g., Roberts et al., 2011; Horng et al., 1998). However, a complete magnetic mineralogy characterization requires further analysis (e.g., thermal demagnetization, isothermal remanent magnetization acquisition, and variation of susceptibility with temperature).

Typical demagnetization behaviors from the two complementary approaches are shown in Figure F20. AF treatments on discrete samples effectively remove a steeper low-coercivity component induced by the drilling overprint (Figure F20A, F20E). AF treatment on section halves may not be sufficient to isolate a stable ChRM vector (Figure F20B, F20F) because it cannot completely remove the drilling overprint (up to $25 \mathrm{mT}$ ). Furthermore, the maximum field strength of in-line AF demagnetization is limited because of the destructive nature of the treatments and our limited ability to measure weak magnetizations in the nonmagnetically shielded shipboard environment. As a consequence, the archive-half sections exhibit a drilling-induced overprint that results in a prevalence of positive directions (unimodal distribution of the magnetization components; Figure F20).
Normal and reversed polarities are documented in the archivehalf sections and validated by AF demagnetization of discrete samples (Figure F21). However, the observed inclinations cannot be correlated with a reference geomagnetic polarity timescale because of the extremely low recovery rate. A correlation could be attempted with the addition of paleontological age constraints.

\section{Basalts}

The archive-half sections of basalts from Cores 368X-U1503A70R through 88R (1605.4-1705.77 m), excluding intervals that were too highly fractured, were measured on the SRM at a $2.0 \mathrm{~cm}$ spacing. After measuring the NRM, the cores were subjected to a stepwise in-line AF demagnetization at an incremental rate of $2 \mathrm{mT}$ from 2 to $10 \mathrm{mT}$ and at a rate of $5 \mathrm{mT}$ from 10 to $25 \mathrm{mT}$. The average initial intensity of magnetization for basalts (lithostratigraphic Unit IV) is on the order of $1 \mathrm{~A} / \mathrm{m}$.

A total of 19 basalt discrete samples were measured at room temperature and after AF demagnetization at 2, 4, 6, 8, 10, 15, 20, $25,30,35$, and $40 \mathrm{mT}$ steps. Both discrete samples and archive-half sections show the presence of a lower coercivity component characterized by different polarities and steepness that is not necessarily associated with drilling overprint. The ChRMs are isolated in two different intervals: (1) between 4 and 15 (or 20) mT or (2) between 6 (or 10) and 35 (or 40) mT. Typical examples of demagnetization behavior are shown in Figure F22.

Demagnetization data from discrete samples and archive-half sections led to comparable results. Normal and reversed polarities are documented in the basalts from archive-half sections and validated by AF demagnetization of discrete samples (Figure F23). Because the basalts could be completely demagnetized at $20 \mathrm{mT}$, the demagnetization step at $15 \mathrm{mT}$ is plotted against depth as more representative of their ChRMs (Figure F24).

\section{Sediments}

\section{Anisotropy of magnetic susceptibility}

The 43 discrete sediment samples have an average magnetic susceptibility $(K)$ of $486 \times 10^{-6}$ SI and a maximum value of $1050 \times$ $10^{-6} \mathrm{SI}$ in lithostratigraphic Unit II and a minimum value of $130 \times$ $10^{-6} \mathrm{SI}$ in Unit III. The degree of magnetic anisotropy $P^{\prime}$ is moderate $(\sim 1.12)$, and the fabric is strongly oblate, as shown by the shape parameter ( $T$ ) (Figure F25). According to the Fisher distribution of AMS principal axes, this suggests a nearly horizontal planar fabric that is consistent with deposition in a calm pelagic environment with very limited bottom currents. An inclined planar fabric present in Unit II shows a bedding inclined by $\sim 30^{\circ}$, according to structural data (see Lithostratigraphy).

\section{Basalts}

The 19 basalt discrete samples show a $K$ of $4.22 \times 10^{-2}$ SI and a low $P^{\prime}$ (average $=1.09$ ), which is typical of titanomagnetite.

The $T$ indicates mainly a prolate shape of the ellipsoid (Figure F25). Overall, basalts show an intermediate fabric consistent with viscous magmatic flow. However, it is currently not possible to determine the direction of the flow because samples are not fully oriented. 
Figure F20. Demagnetization plots of (A, C, E, G) discrete sediment samples and (B, D, F, H) equivalent archive-half sections, Hole U1503A. Zijderveld plots: solid squares $=$ declination, open squares $=$ inclination. Stereographic plots: solid squares $=$ positive $($ down $)$ inclination, open squares $=$ negative (up) inclination. Red = steps used to calculate ChRM. A-D. Examples from Unit I of (A, B) higher coercivity ChRM where a low-coercivity component can be isolated in the discrete sample but not in the archive-half section and (C, D) lower coercivity remanence with similar ChRMs in the discrete sample and archive-half section. E, F. Examples from Unit II of higher coercivity ChRM where a low-coercivity component can be isolated in the discrete sample but not in the archive-half section. G, H. Examples from Unit III of demagnetization behavior.

Discrete samples

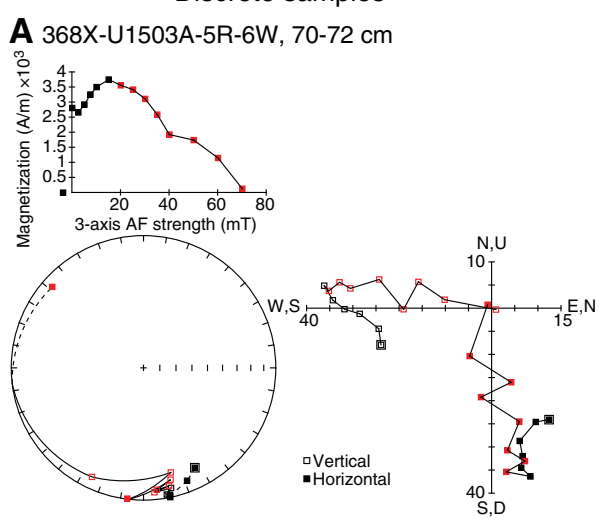

C 368X-U1503A-16R-3W, 78-80 cm

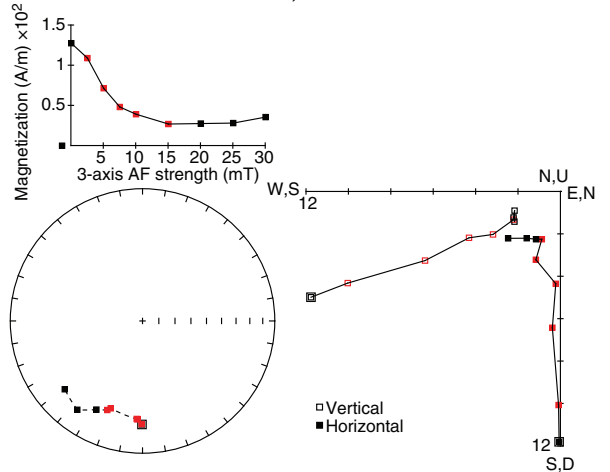

E 368X-U1503A-54R-4W, 74-76 cm
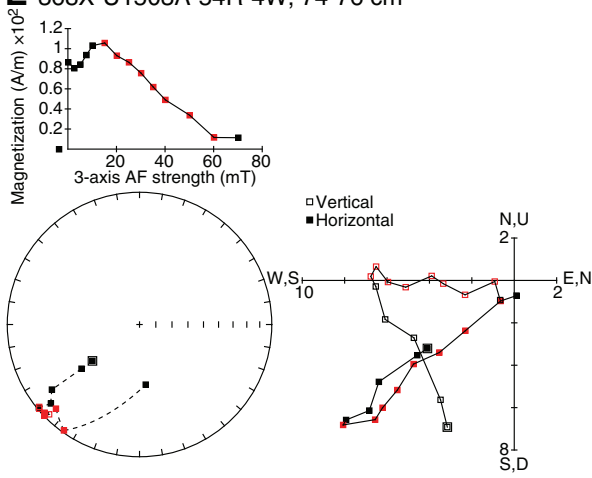

G 368X-U1503A-69R-1W, 70-72 cm

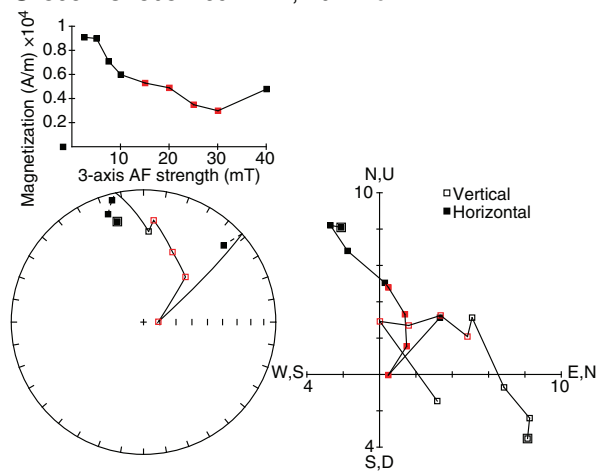

Half cores

B 368X-U1503A-5R-6A, $70 \mathrm{~cm}$

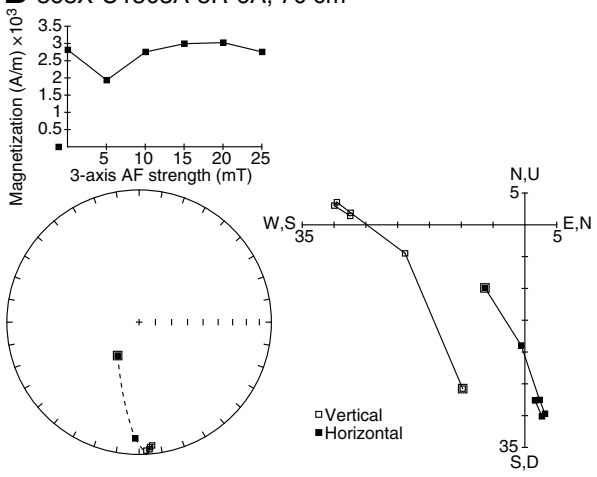

D 368X-U1503A-16R-3A, $77.5 \mathrm{~cm}$

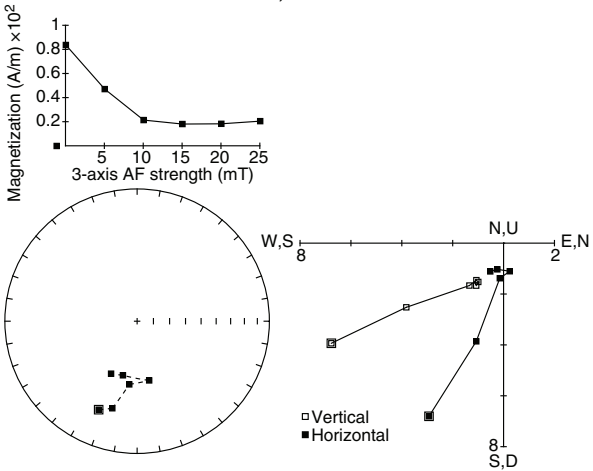

F 368X-U1503A-54R-4A, $75 \mathrm{~cm}$

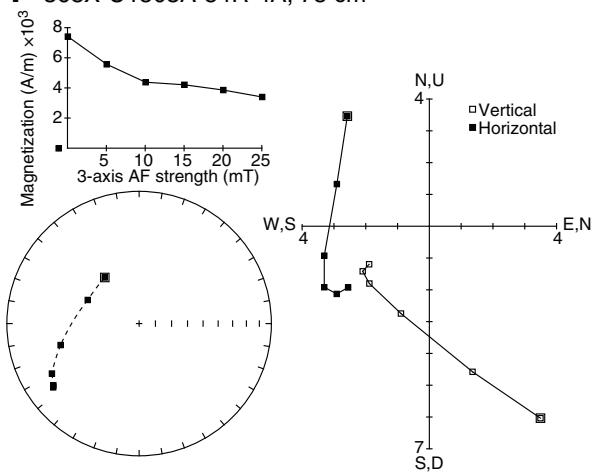

H 368X-U1503A-69R-1A, $70 \mathrm{~cm}$

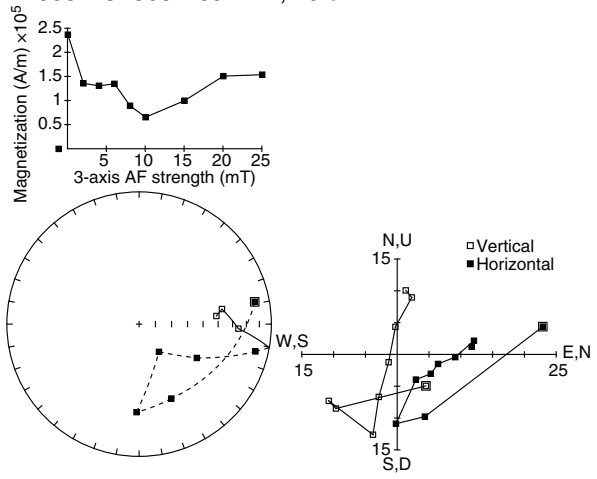


Figure F21. A. Expected intensity changes for Hole U1503A sediments after demagnetizing archive-half sections and relative NRM ratios estimated based on all AF demagnetization (AFD) steps. Two subpopulations were identified (Ratio-1 and Ratio-2). B, C. Inclination changes of all archive-half sections from NRM and $25 \mathrm{mT}$ AFD and their expectations with $1 \sigma$ uncertainties (red). Discrete NRM and ChRM: blank rectangle = positive inclination, blue rectangle $=$ negative inclination.
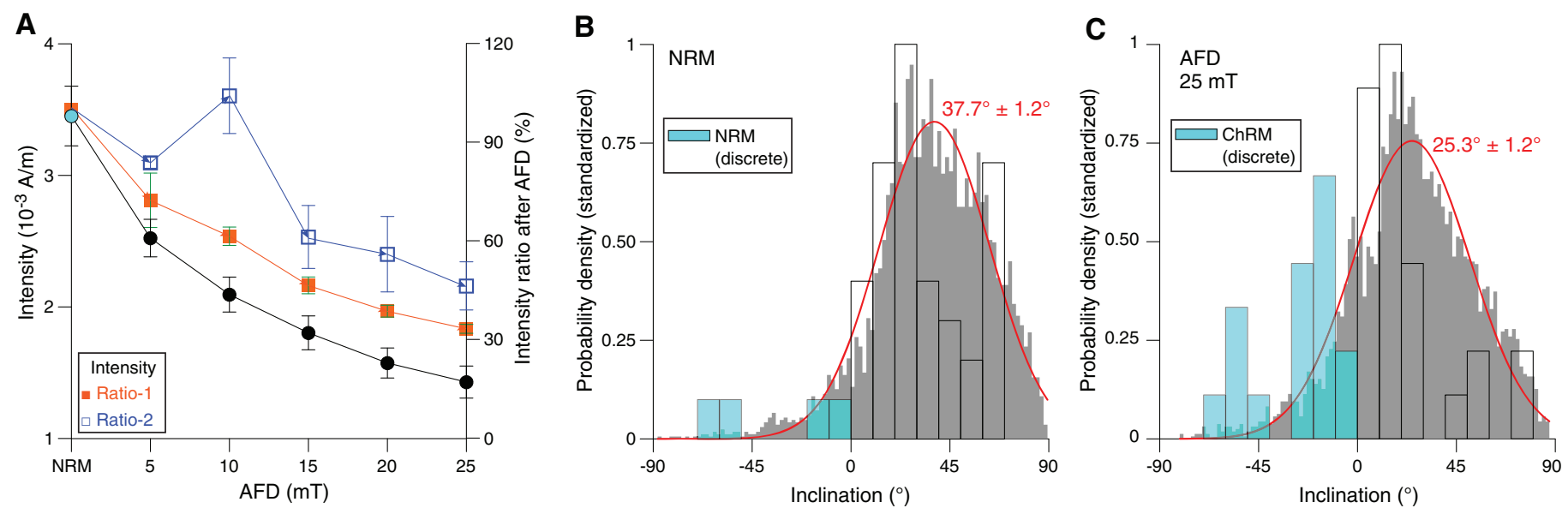

Figure F22. Demagnetization plots of (A, C) discrete basalt samples and (B, D) equivalent archive-half sections, Hole U1503A. Zijderveld plots: solid squares = declination, open squares $=$ inclination. Stereographic plots: solid squares $=$ positive $($ down) inclination, open squares $=$ negative (up) inclination. Red $=$ steps used to calculate ChRM. A, B. Samples demagnetized at higher coercivity, where a complete demagnetization could be obtained in the discrete sample but not in the archive-half section. C, D. Samples demagnetized at lower coercivity showing similar ChRM up to $15 \mathrm{mT}$.

Discrete samples

A 368X-U1503A-72R-1W, 29-31 cm
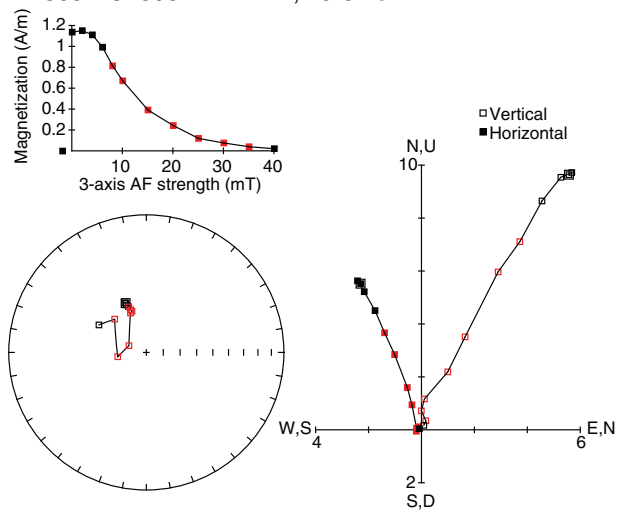

C 368X-U1503A-80R-2W, $46-48 \mathrm{~cm}$
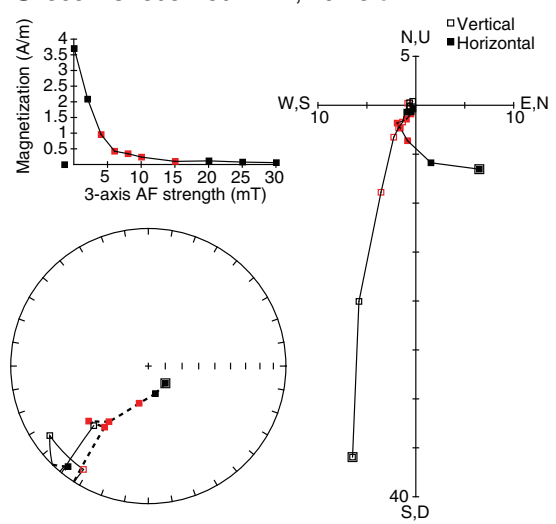

Half cores

B 368X-U1503A-72R-1A, $28 \mathrm{~cm}$
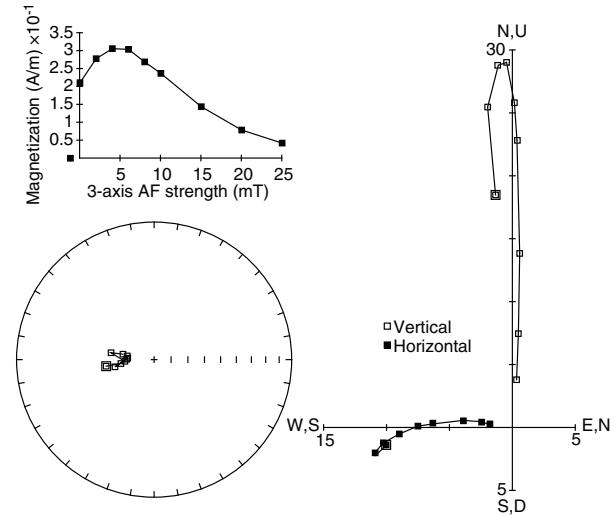

D 368X-U1503A-80R-2A, $46 \mathrm{~cm}$

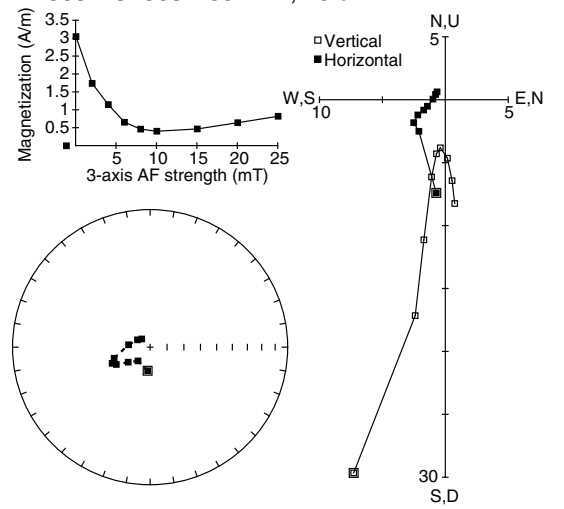


Figure F23. A. Expected intensity changes for Hole U1503A basalts after demagnetizing archive-half sections and relative NRM ratios. Estimation based on all AFD steps. Two subpopulations were identified (Ratio-1 and Ratio-2). B, C. Inclination changes of all archive-half sections from NRM and 25 mT AFD and their expectations with $1 \sigma$ uncertainties (red). Discrete NRM and ChRM: blank rectangle = positive inclination, blue rectangle = negative inclination.
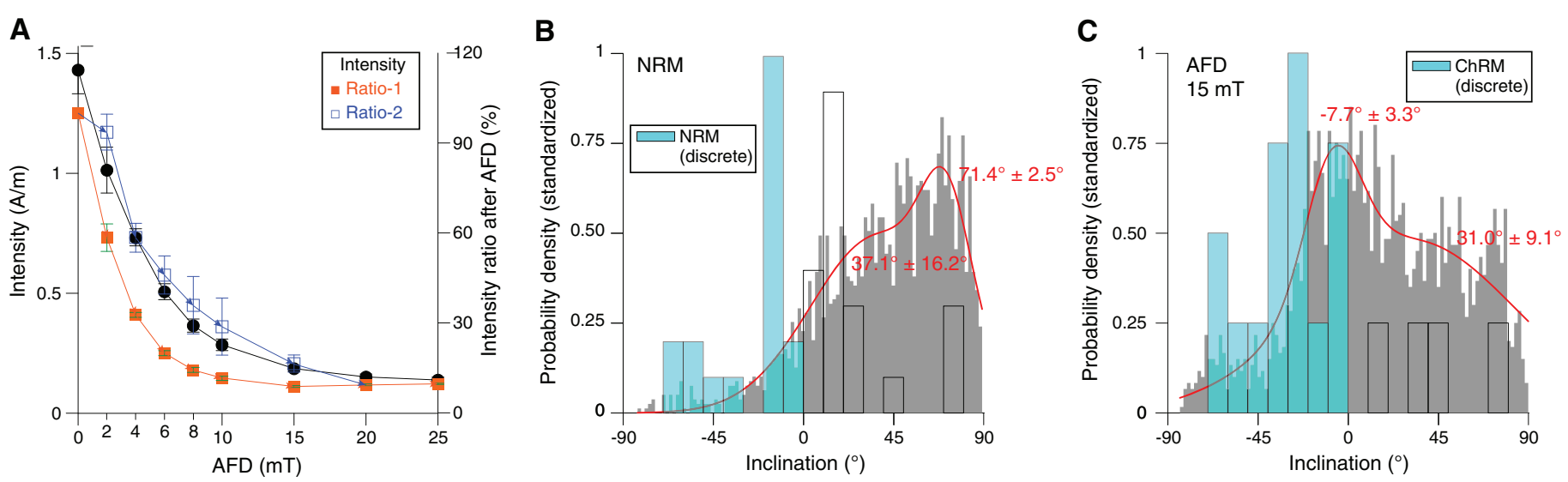

Figure F24. Paleomagnetic measurements, Hole U1503A.

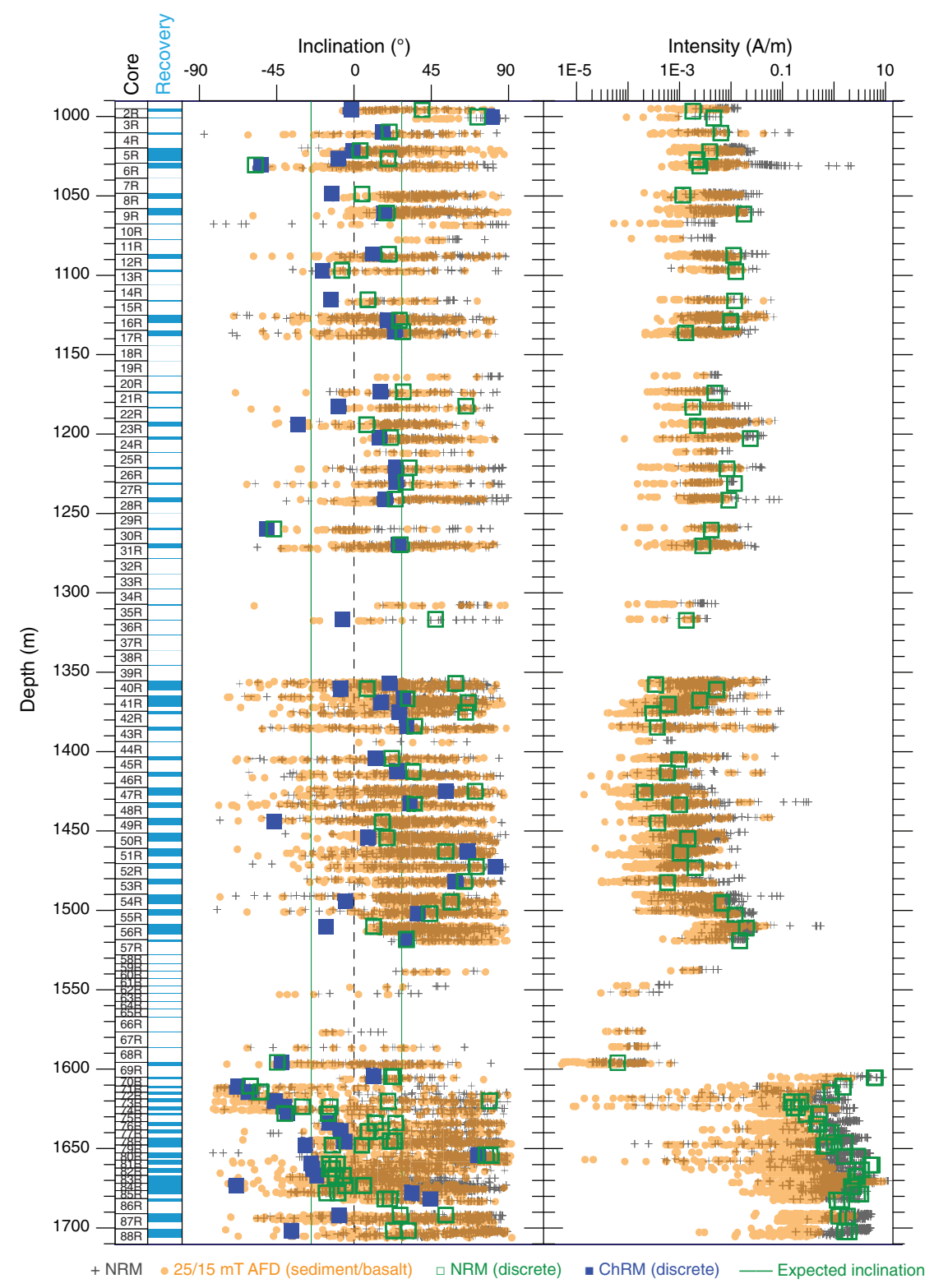


Figure F25. AMS data for (A, B) discrete sediment and (D, E) basalt samples, Hole U1503A. A, D. Stereonet of AMS directions (lower hemisphere, equal area projection). $K_{1}=$ maximum principal axis, $K_{2}=$ intermediate principal axis, $K_{3}=$ minimum principal axis. Confidence ellipses at $95 \%$ level are shown in corresponding color. Tensorial means are shown with larger symbols of the same color. B, E. Degree of magnetic anisotropy $\left(P^{\prime}\right)$ vs. magnetic susceptibility $\left(K_{\mathrm{m}}\right)$. C, F. Magnetic shape parameter $(T)$ vs. $P^{\prime}$. Sediments exhibit dominant planar and subhorizontal fabric and strong oblate shape, which is less marked and exhibits a slight decrease in $P^{\prime}$ consistent with sedimentary fabric acquired in a calm pelagic environment. Samples from Units II and III (darker symbols) exhibit an inclination of the fabric as much as $\sim 30^{\circ}$ (368X-U1503A-69R-1W, 70-72 cm; Unit III). Basalts exhibit a prolate fabric suggesting the presence of a flow.
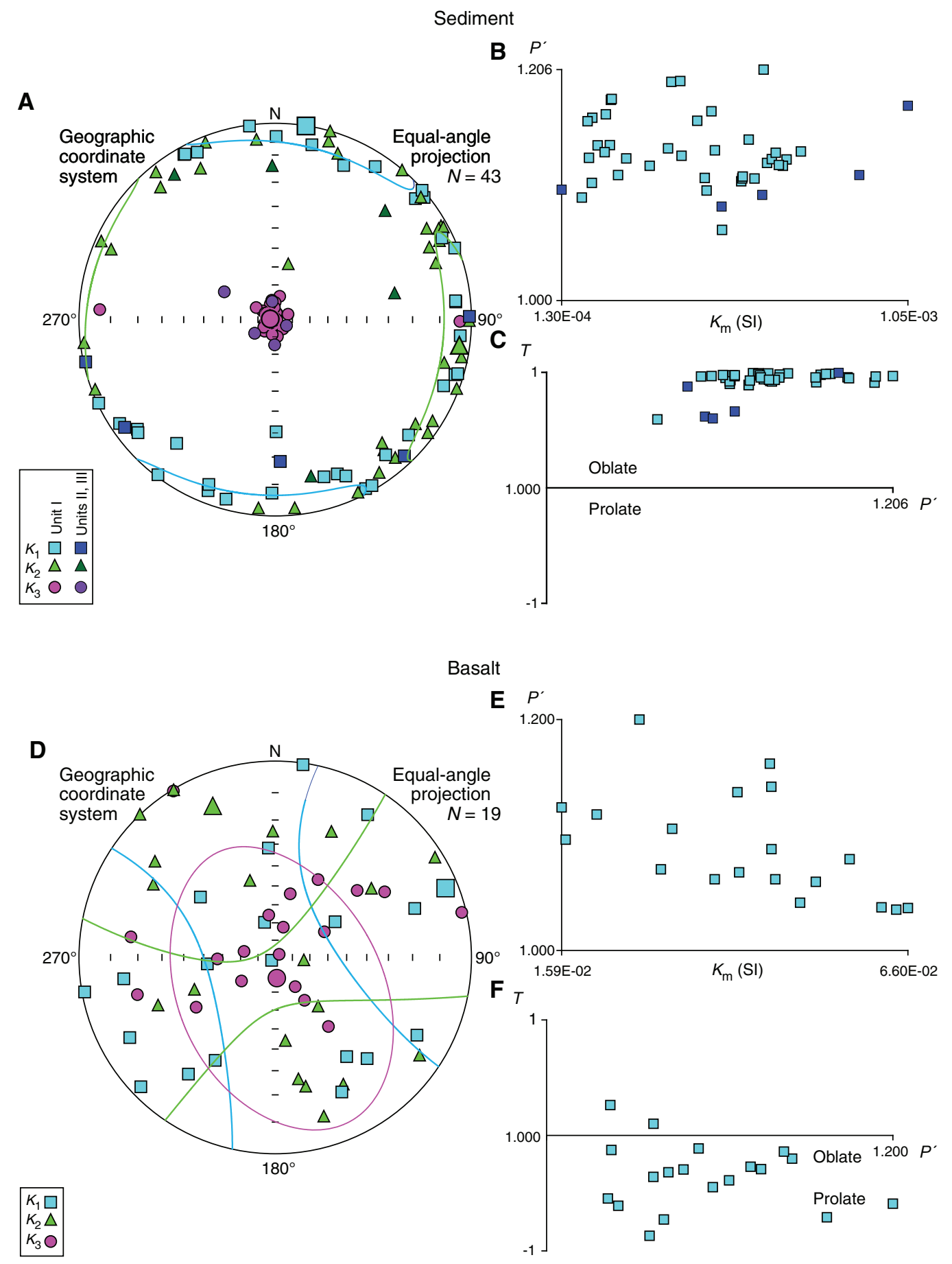


\section{Geochemistry \\ Headspace gas}

At Site U1503, 57 headspace gas samples were analyzed for routine safety monitoring in all sediment cores (995.1-1597.84 m). Two basement samples (1606.25 and $1647.81 \mathrm{~m}$ ) were also analyzed. Methane content is low ( $<30 \mathrm{ppmv})$ in the sediment sections between 995.1 and $1394 \mathrm{~m}$ (Table T8). Deeper than $1404 \mathrm{~m}$, methane gradually increases (average $=1249$ ppmv) before reaching a maximum of $5066 \mathrm{ppmv}$ at $1596.78 \mathrm{~m}$, which is very near the sediment/basement boundary. In the two basement samples, methane content ranges from 528.60 to 4863.85 ppmv. Methane content in basement material could be abiogenic, resulting from carbonbearing fluid alteration of basalt at low temperatures.

\section{Bulk sediment geochemistry}

Total carbon (TC), total inorganic carbon (TIC), calcium carbonate $\left(\mathrm{CaCO}_{3}\right)$, total organic carbon (TOC), total nitrogen (TN), and total sulfur (TS) were determined on 43 discrete sediment samples (Table T9; Figure F26). Bulk sediment TC and TN were determined by elemental analysis, and TIC was determined by coulometer (see the Expedition 367/368 methods chapter [Sun et al., 2018a]).

Table T8. Headspace gas, Hole U1503A. Download table in CSV format.

Table T9. Carbon, nitrogen, and sulfur, Hole U1503A. Download table in CSV format.
TIC contents range from $<0.1$ to $3.81 \mathrm{wt} \%$ (average $=0.61 \mathrm{wt} \%$ ) in sediments. Calcium carbonate content, assuming inorganic carbon is exclusively present as $\mathrm{CaCO}_{3}$, varies between $<0.1$ and 31.7 $\mathrm{wt} \%$ (average $=5.04 \mathrm{wt} \%$ ). Carbonate content $>30 \mathrm{wt} \%$ found near the top of the cored sediments (1000.88-1067.9 m) corresponds to sandstones in lithostratigraphic Unit I. Near the sediment/basement interface (1597.52 m), a claystone from Unit III also contains $>30 \mathrm{wt} \%$ carbonate.

TC content varies between $<0.1$ and $4.44 \mathrm{wt} \%$. TOC content averages $0.24 \mathrm{wt} \%$ but is below detection limit in 23 samples, primarily between 1173.86 and $1270.17 \mathrm{~m}$ and between 1483.28 and 1519.04 m (Table T9; Figure F26). Elemental TOC/TN ratios are generally used as a preliminary estimate for the source of organic material. High values (TOC/TN > 12) are typically attributed to a predominantly terrestrial source, and lower values $(\mathrm{TOC} / \mathrm{TN}<8)$ are indicative of dominantly marine contributions (Müller and Mathesius, 1999). With three exceptions, TOC/TN ratios range from $<1$ to 6.4 (average $=4.3$ ) at Site U1503 (Table T9; Figure F26), suggesting that the majority of the organic matter is likely from a marine source. High TOC/TN ratios (15.0-21.3) are at the same depth intervals as the sandstones in lithostratigraphic Unit I and the claystones in Unit III that contain $>30 \%$ carbonate.

\section{Source rock analysis}

Three samples from Site U1503 were analyzed using the source rock analyzer (Table T10). TOC content can be more than double the TOC content calculated for the same sample by coulometer. The temperature at the maximum of the $\mathrm{S} 2$ peak $\left(T_{\max }\right)$ is an indicator of rock maturity. $T_{\max }$ values suggest thermal immaturity $\left(T_{\max }<435^{\circ} \mathrm{C}\right)$. 
Figure F26. Lithology and geochemical profiles, Hole U1503A. cps = counts per second.

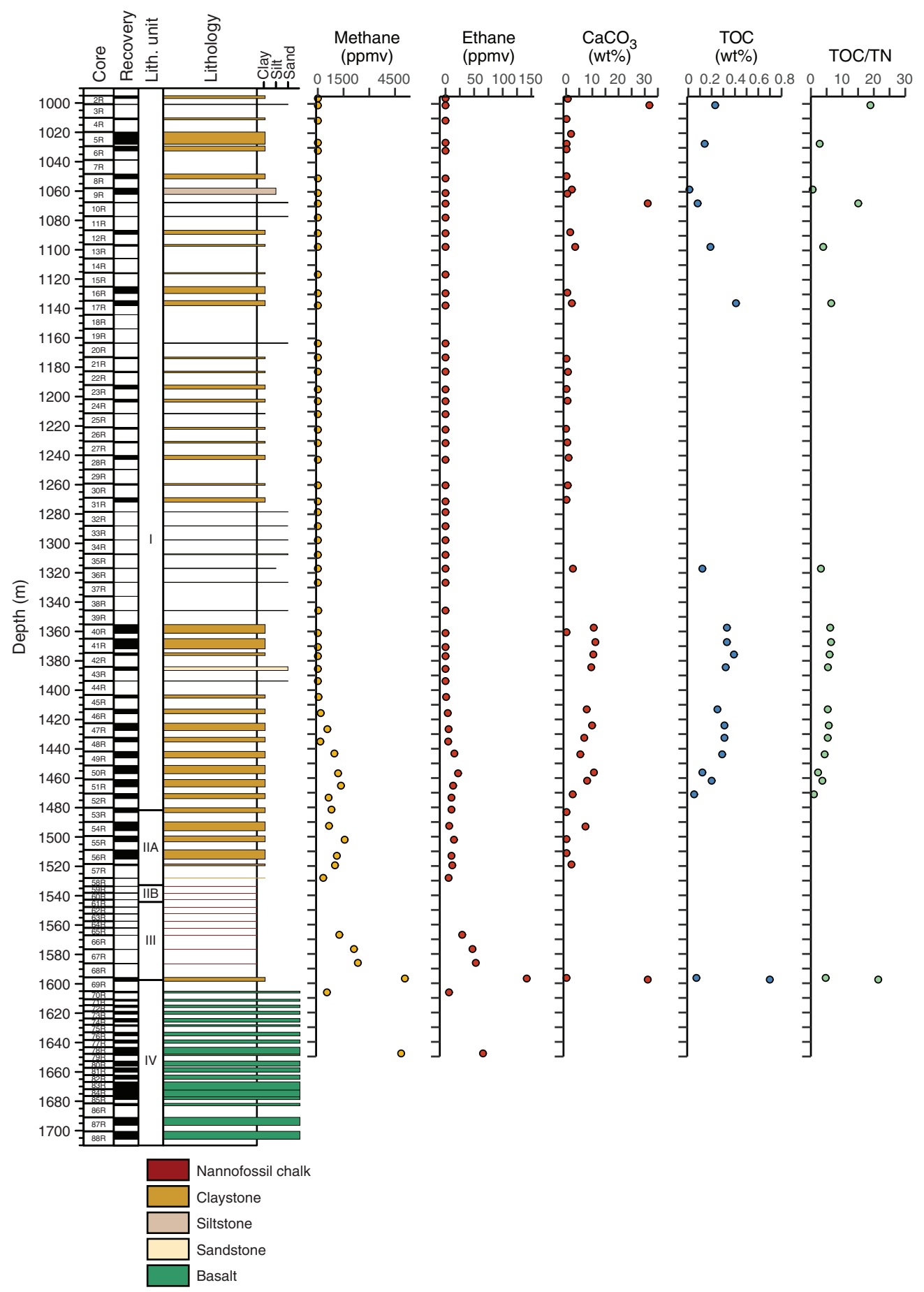

Table T10. Source rock analysis, Hole U1503A. $\mathrm{HC}=$ hydrocarbon, $T_{\max }=$ nominal temperature of the maximum rate of hydrocarbon yield, $\mathrm{HI}=$ hydrogen index, $\mathrm{OI}=$ oxygen index, $\mathrm{PI}$ = production index. Download table in CSV format.

\begin{tabular}{|c|c|c|c|c|c|c|c|c|c|}
\hline $\begin{array}{l}\text { Core, section, } \\
\text { interval }(\mathrm{cm})\end{array}$ & $\begin{array}{l}\text { Depth } \\
\text { (m) }\end{array}$ & $\begin{array}{c}\mathrm{S} 1 \\
(\mathrm{mg} \mathrm{HC} / \mathrm{gC})\end{array}$ & $\begin{array}{c}\mathrm{S} 2 \\
(\mathrm{mg} \mathrm{HC} / \mathrm{gC})\end{array}$ & $\begin{array}{c}\mathrm{S3} \\
(\mathrm{mg} \mathrm{HC} / \mathrm{g} \mathrm{C})\end{array}$ & $\begin{array}{l}T_{\max } \\
\left({ }^{\circ} \mathrm{C}\right)\end{array}$ & $\begin{array}{l}\text { TOC } \\
\text { (wt\%) }\end{array}$ & $\mathrm{HI}$ & OI & $\mathrm{PI}$ \\
\hline \multicolumn{10}{|l|}{ 368X-U1503A- } \\
\hline $3 R-1,8-9$ & 1000.88 & 0.46 & 0 & 0.51 & 336.32 & 0.2 & 0 & 256 & 1 \\
\hline $17 \mathrm{R}-1,133-135$ & 1136.03 & 0.49 & 0.29 & 0.59 & 414.66 & 0.86 & 34 & 69 & 0.63 \\
\hline $46 \mathrm{R}-1,11-13$ & 1413.01 & 0.46 & 0.04 & 0.62 & 423.92 & 0.94 & 4 & 66 & 0.92 \\
\hline
\end{tabular}




\section{Physical properties}

We measured physical properties on whole-round cores, working-half sections, and discrete samples. These measurements included gamma ray attenuation (GRA) bulk density, magnetic susceptibility, natural gamma radiation (NGR), $P$-wave velocity, moisture and density (MAD) and porosity, and thermal conductivity. We used the Whole-Round Multisensor Logger (WRMSL) to measure GRA bulk density and magnetic susceptibility. No $P$-wave velocity was measured using the WRMSL because of the large gap between the core and core liner produced during RCB coring. NGR was measured on whole-round cores with the Natural Gamma Radiation Logger (NGRL). After the cores were split into section halves, $P$-wave velocity was measured with the Section Half Measurement Gantry (SHMG) using the $X$-caliper for measurements through the split cores, and usually at least one measurement was made per section. No velocity measurement was performed with the $Y$ - and $Z$ bayonets on the SHMG because the sample material was too hard for the bayonets to penetrate without disrupting and introducing cracks. Discrete samples were taken for MAD measurements, including mass measurement with dual balances and volume measurement with a pycnometer. For MAD measurements of hard sediment and basalt, small pieces or cubes were cut from samples of the working-half sections. The resulting MAD values were used to calculate bulk properties (wet bulk density, dry bulk density, sediment grain density, porosity, and void ratio).

For Cores 368X-U1503A-70R through 88R (1605.0-1710.1 m), $P$-wave measurements were made with the caliper on individual basalt core pieces with a core liner. Discrete samples from these cores were shared between the paleomagnetism and physical properties groups. First, samples were measured for paleomagnetism using AF demagnetization but no heating. Afterward, the samples were measured for $P$-wave velocity on the SHMG. Samples were then split into two residues, and the bottom residues of the cubes were mea- sured for MAD. We soaked the samples in saltwater for $4 \mathrm{~h}$ under a vacuum and then performed MAD measurements (see Physical properties in the Expedition 367/368 methods chapter and Physical properties in the Expedition $368 \mathrm{X}$ methods supplement chapter [Sun et al., 2018a; Childress et al., 2020]).

Throughout all cores, thermal conductivity was measured on working-half sections with a puck probe. Good contact results were obtained after smoothing the surface of the rock with sandpaper. For each core, three measurements were conducted, but this number was increased to as many as six measurements when the three measurements were notably different. Before thermal conductivity was measured with a puck in the bath, hard rock samples were placed in a seawater bath for $4 \mathrm{~h}$ for Cores 368X-U1503A-70R through 79R (1605.0-1652.7 $\mathrm{m}$ ) and in a seawater bath under vacuum for $1 \mathrm{~h}$ for Cores 80R through 88R (1652.7-1710.1 m).

Data measurements using automatic systems such as the WRMSL, NGRL, and Section Half Multisensor Logger (SHMSL; point magnetic susceptibility) can contain data outliers (e.g., data from voids in the core, unrealistic high/low values, etc.). Artifact magnetic susceptibility data that were clearly due to the presence of broken pieces of metal from the drilling equipment were removed by hand. Because the values in the basalt layers are very different from those in the sediment, we estimated the mean and standard deviation for the two data sets separately (Table T11). The WRMSL measurements on the basalt cores (Section 368X-U1503A-69R-2 to the bottom of the hole; $1597.8-1710.1 \mathrm{~m}$ ) are very scattered because of voids in the liner between rock pieces. The corresponding standard deviation is relatively high (Table T11).

The variations in physical property values have led us to distinguish intervals defining Physical Property (PP) Units 1-9, each with specific characteristics (Table T12). Lithostratigraphic Unit I includes PP Units 1-5. Subunit IIA includes PP Units 6 and 7. Subunit IIB and Unit III correspond to PP Unit 8. Unit IV corresponds to PP Unit 9.

Table T11. Mean and standard deviation of physical property measurements data sets for sediment (995.1-1597.8 m) and underlying basalt, Hole U1503A. High standard deviation (Stdev) of Whole-Round Multisensor Logger (WRMSL) magnetic susceptibility (MS) and natural gamma radiation (NGR) in basalt reflects the presence of voids in the core liner between rock pieces. MAD = moisture and density. Download table in CSV format.

\begin{tabular}{|c|c|c|c|c|c|c|c|c|c|c|c|c|}
\hline & \multicolumn{2}{|c|}{$\begin{array}{l}\text { WRMSL NGR } \\
\text { (counts/s) }\end{array}$} & \multicolumn{2}{|c|}{$\begin{array}{l}\text { MAD bulk density } \\
\left(\mathrm{g} / \mathrm{cm}^{3}\right)\end{array}$} & \multicolumn{2}{|c|}{$\begin{array}{c}\text { WRMSL MS } \\
\left(10^{-5} \mathrm{SI}\right)\end{array}$} & \multicolumn{2}{|c|}{$\begin{array}{c}P \text {-wave velocity } \\
(\mathrm{m} / \mathrm{s})\end{array}$} & \multicolumn{2}{|c|}{$\begin{array}{l}\text { MAD porosity } \\
(\%)\end{array}$} & \multicolumn{2}{|c|}{$\begin{array}{l}\text { Thermal conductivit) } \\
(\mathrm{W} /[\mathrm{m} \cdot \mathrm{K}])\end{array}$} \\
\hline & Mean & Stdev & Mean & Stdev & Mean & Stdev & Mean & Stdev & Mean & Stdev & Mean & Stdev \\
\hline Sediment & 65.18 & 9.65 & 2.31 & 0.1 & 32.01 & 15.89 & 2948 & 634 & 26.1 & 6.4 & 2.68 & 1.01 \\
\hline Basalt & 3.57 & 1.63 & 2.71 & 0.09 & 1554.01 & 936.2 & 4537 & 510 & 10.06 & 4.19 & 1.66 & 0.18 \\
\hline
\end{tabular}

Table T12. Comparison of physical property (PP) and lithostratigraphic units, Hole U1503A. Download table in CSV format.

\begin{tabular}{|c|c|c|c|}
\hline \multirow{2}{*}{$\begin{array}{l}\text { PP } \\
\text { unit }\end{array}$} & \multicolumn{2}{|c|}{ Depth $(m)$} & \multirow{2}{*}{$\begin{array}{l}\text { Lith. } \\
\text { unit }\end{array}$} \\
\hline & From & To & \\
\hline 1 & 995.1 & 1062.3 & I \\
\hline 2 & 1062.3 & 1086.8 & I \\
\hline 3 & 1086.8 & 1355.3 & I \\
\hline 4 & 1355.3 & 1371.9 & I \\
\hline 5 & 1371.9 & 1484.7 & I \\
\hline 6 & 1484.7 & 1499.3 & $\| A$ \\
\hline 7 & 1499.3 & 1528.0 & $\| A$ \\
\hline 8 & 1528.0 & 1597.8 & IIB-III \\
\hline 9 & 1597.8 & 1710.1 & IV \\
\hline
\end{tabular}




\section{Natural gamma radiation}

In lithostratigraphic Unit I (995.1-1484.7 m), NGR ranges from 30 to 80 counts/s, and there is a significant difference between 60 and 80 counts/s in the claystone and between 30 and 50 counts $/ \mathrm{s}$ in the sandstone (Figure F27; Tables T11, T12). PP Units 1-5 were defined mostly based on variations in NGR and magnetic susceptibility (Table T12). NGR is 60-80 counts/s in PP Units 1 and 4, 30-50 counts/s in PP Unit $2,30-80$ counts/s in PP Unit 3, and 60-80 counts/s in PP Unit 5. In Unit II (1484.7-1542.8 m), NGR in PP Unit 6 is similar to that in PP Unit 5 , and NGR decreases to $\sim 50$ counts/s in PP Unit 7. We did not measure NGR in PP Unit 8 because Sections 368X-U1503A-58R-CC through 68R-CC are too short. Basalts in Unit IV have very low NGR, almost entirely $<10$ counts/s, which is expected for basalt.

\section{Magnetic susceptibility}

Magnetic susceptibility was measured on the WRMSL (core magnetic susceptibility) and SHMSL (point magnetic susceptibility). Magnetic susceptibility is sensitive to magnetic mineral content and mineralogy of the formation (e.g., Clark and Emerson, 1991). Core magnetic susceptibility and point magnetic susceptibility are in very good agreement throughout the entire cored section (Figure F27). Peaks in magnetic susceptibility near $1501.5 \mathrm{~m}$ (Section 368XU1503A-55R-2) and $1510.7 \mathrm{~m}$ (Section 56R-2) are likely artifacts caused by the presence of broken pieces of metal from the drilling equipment. Such artificial anomalies do not appear in the point magnetic susceptibility measurements.

Magnetic susceptibility in lithostratigraphic Unit I (995.1$1484.7 \mathrm{~m}$ ) is relatively uniform, from $30 \times 10^{-5}$ to $45 \times 10^{-5} \mathrm{SI}$, in the claystone in much of PP Units 1,3 , and 4. Magnetic susceptibility is lower, from $15 \times 10^{-5}$ to $40 \times 10^{-5} \mathrm{SI}$, in the sandstone in PP Units 2 and 5 (Figure F27). In PP Unit 6 (1484.7-1499.3 m), magnetic susceptibility values are similar to those just above in PP Unit 5. In PP Unit 7 (1499.3-1528.0 m), magnetic susceptibility increases markedly to $\sim 100 \times 10^{-5} \mathrm{SI}$, corresponding to the red clay of Subunit IIA, and then decreases to $\sim 80 \times 10^{-5} \mathrm{SI}$ in the lower part of Subunit IIA. In Subunit IIB and Unit III (PP Unit 8), magnetic susceptibility decreases from $\sim 25 \times 10^{-5}$ to $<10 \times 10^{-5} \mathrm{SI}$. In the basalt in Unit IV (PP Unit 9), magnetic susceptibility values are two orders of magnitude higher, increasing to $\sim 1500 \times 10^{-5}$ to $7000 \times 10^{-5} \mathrm{SI}$, than those in the sediment units. Magnetic susceptibility values from the basalts are scattered (Figure F28) because of the presence of voids in the measurements and the large size variation of the basalt pieces. Magnetic susceptibility in Cores 368X-U1503A-70R through 86R $(1605.0-1683.0 \mathrm{~m})$ is between $1500 \times 10^{-5}$ and $4000 \times 10^{-5} \mathrm{SI}$. Magnetic susceptibility increases in Cores $87 \mathrm{R}$ and $88 \mathrm{R}$ to reach a maximum of $\sim 7000 \times 10^{-5} \mathrm{SI}$ in Section 88R-2 (1701.8-1702.8 m). Magnetic susceptibility then decreases to $1000 \times 10^{-5}$ to $2000 \times 10^{-5}$ SI in Sections 88R-3 through 88R-4 (Figure F28).

\section{$P$-wave velocity}

$P$-wave velocity whole-round measurements were not made on Hole U1503A cores because the contact between the cores and liners was poor for RCB coring. We measured $P$-wave velocity directly on working-half Sections 368X-U1503A-2R-1 through 88R-4 with the $X$-caliper. $P$-wave velocity in claystone and siltstone (2006-2955 $\mathrm{m} / \mathrm{s}$ ) increases by $\sim 0.8 \mathrm{~m} / \mathrm{s}$ per $1 \mathrm{~m}$ depth in PP Units $1-8$ (995.1$1597.8 \mathrm{~m}$ ) (average $=2569.6 \mathrm{~m} / \mathrm{s}$ ) (Figure F27). Several measurements show significantly higher values between 3026 and $4480 \mathrm{~m} / \mathrm{s}$ that correspond either to measurements in sandstone layers inter- bedded with claystone in PP Units 3 and 5 or measurements on single samples in the low-recovery cores of PP Units 1-3 and 8 (Figure F27). Notably, $P$-wave velocity decreases gradually with depth from $3479 \mathrm{~m} / \mathrm{s}$ at $1533.71 \mathrm{~m}$ to $3054 \mathrm{~m} / \mathrm{s}$ at $1576.62 \mathrm{~m}$ in PP Unit 8. In PP Unit $9, P$-wave velocity in basalt $(3306-5656 \mathrm{~m} / \mathrm{s}$; average $=4537$ $\mathrm{m} / \mathrm{s}$ ) is much higher than in sediments (Figures F27, F28).

\section{Density and porosity}

GRA bulk density was measured automatically every $2 \mathrm{~cm}$ by the WRMSL. In addition, MAD measurements on discrete core samples for Sections 368X-U1503A-2R-1 through 69R-2 were made for 1-3 samples per core according to recovery rate except for the low-recovery cores of PP Units 3, 5, and 8 (Figure F27). GRA bulk density (average $=\sim 1.91 \mathrm{~g} / \mathrm{cm}^{3}$ ) from the WRMSL measurements is lower than MAD bulk density (average $=\sim 2.31 \mathrm{~g} / \mathrm{cm}^{3}$ ) because the reduced diameter of the RCB cores did not completely fill the core liner. MAD bulk density measurements for claystone and siltstone in PP Units $1-8$ are relatively low at $2.11-2.39 \mathrm{~g} / \mathrm{cm}^{3}$ (average = $\sim 2.27 \mathrm{~g} / \mathrm{cm}^{3}$ ) with a relatively high porosity of $20.2 \%-36.1 \%$ (average $=\sim 28.3 \%$ ) (Figure F27). MAD measurements in sandstone show a relatively high bulk density of $2.45-2.64 \mathrm{~g} / \mathrm{cm}^{3}$ (average = $\sim 2.55 \mathrm{~g} / \mathrm{cm}^{3}$ ) and a relatively low porosity of $7.6 \%-16.9 \%$ (average $=$ $\sim 11.08 \%$ ). For claystone and siltstone in PP Units $1-8$, MAD bulk density increases slightly with depth from $\sim 2.21 \mathrm{~g} / \mathrm{cm}^{3}$ at $996.46 \mathrm{~m}$ to $\sim 2.30 \mathrm{~g} / \mathrm{cm}^{3}$ at $1597.72 \mathrm{~m}$ (Figure F27). In the basalt in lithostratigraphic Unit IV (PP Unit 9), MAD bulk density is much higher at $2.58-2.84 \mathrm{~g} / \mathrm{cm}^{3}$ (average $=2.71 \mathrm{~g} / \mathrm{cm}^{3}$ ) and porosity ranges from $1.7 \%$ to $17.6 \%$ (average $=10.06 \%$ ), which is much lower than in the sediment units.

\section{Thermal conductivity}

Thermal conductivity was measured on discrete samples from Sections 368X-U1503A-2R-1 through 88R-1. In PP Units 1-8 above the basement, the thermal conductivity for claystone and siltstone is $0.6-2.69 \mathrm{~W} /(\mathrm{m} \cdot \mathrm{K})$ (average $=2.02 \mathrm{~W} /[(\mathrm{m} \cdot \mathrm{K}])$, but the thermal conductivity for sandstone is significantly higher at $2.71-5.44 \mathrm{~W} /(\mathrm{m} \cdot \mathrm{K})$ (average $=3.75 \mathrm{~W} /[\mathrm{m} \cdot \mathrm{K}]$ ) (Figure F27). Thermal conductivity in the basalts ranges from 1.45 to $2.32 \mathrm{~W} /(\mathrm{m} \cdot \mathrm{K})($ average $=1.66 \mathrm{~W} /[(\mathrm{m} \cdot \mathrm{K}])$ in PP Unit 9 (Figure F28).

\section{Data interpretation and lithology correlation Correlation with lithology}

Physical property values for the claystone, siltstone, and sandstone in lithostratigraphic Units I and II (995.1-1542.8 m) do not display large contrasts with depth, but the sandstone in these units has higher bulk density and $P$-wave velocity and lower NGR and magnetic susceptibility than the claystone and siltstone (Figure F27). Deeper layers also exhibit variations that can be correlated to the lithology. For example, the claystone in Subunit IIA (1484.7$1533.6 \mathrm{~m}$ ) correspond to PP Units 6 and 7 and have a combination of high NGR, high magnetic susceptibility, $P$-wave velocity $<3000$ $\mathrm{m} / \mathrm{s}$, and low thermal conductivity that is not observed elsewhere in Hole U1503A.

The nannofossil-rich claystone in lithostratigraphic Unit III (1542.8-1597.8 m), which corresponds to PP Unit 8, displays a clear decrease with depth in bulk density, magnetic susceptibility, and $P$ wave velocity. Such variations, which are opposite to what is expected as a result of lithification or compaction effects, are possibly due to the abundance of nannofossils in the sediment.

The magnetic mineral content of claystones, siltstones, or sandstones and their mineralogy are reflected in magnetic susceptibility 
Figure F27. Physical property measurements summary for sediments and basalt, Hole U1503A. Note log scale for MS.

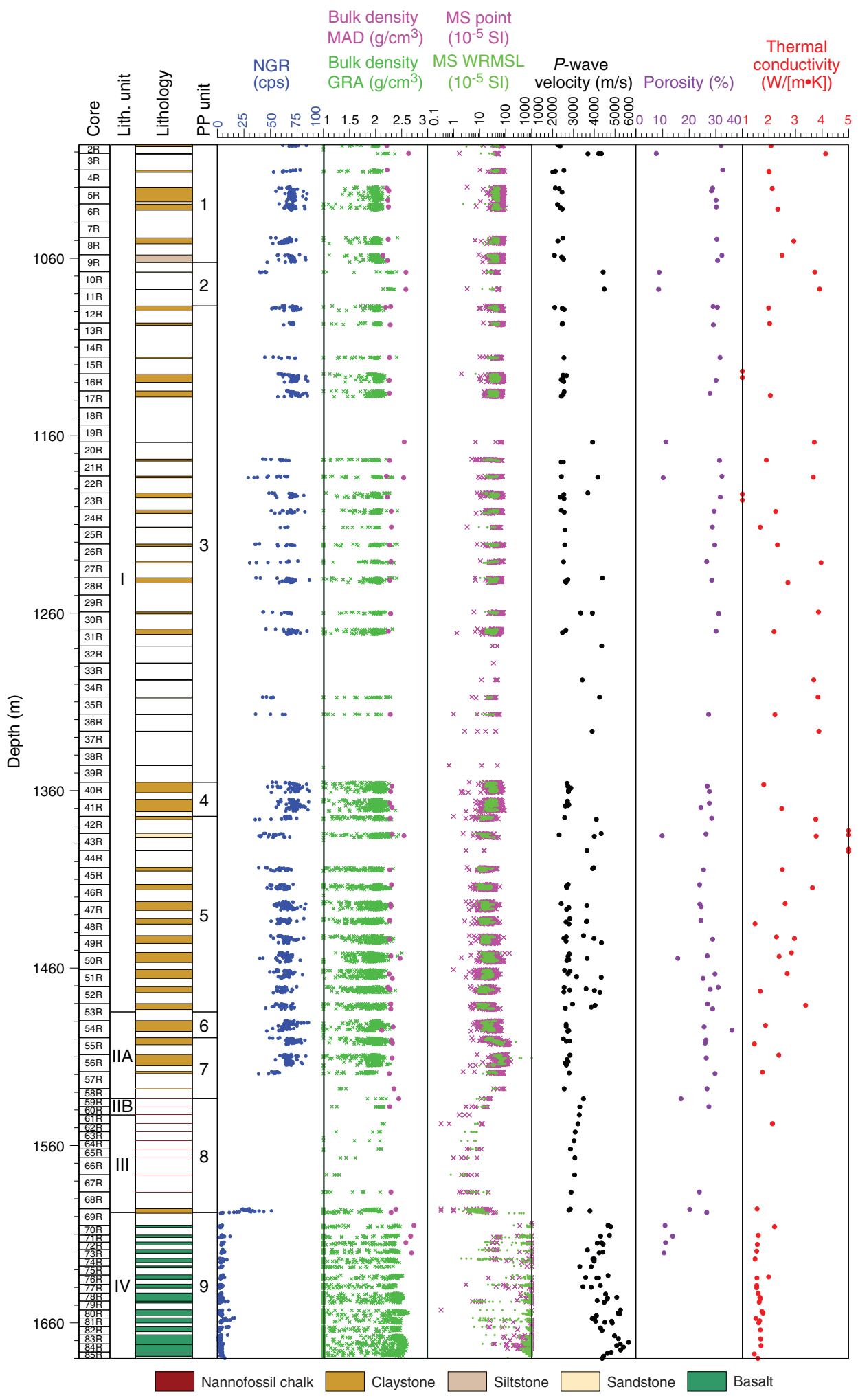


Figure F28. Physical property measurements summary for basalts in Unit IV (PP Unit 9), Hole U1503A. Note log scale for MS.

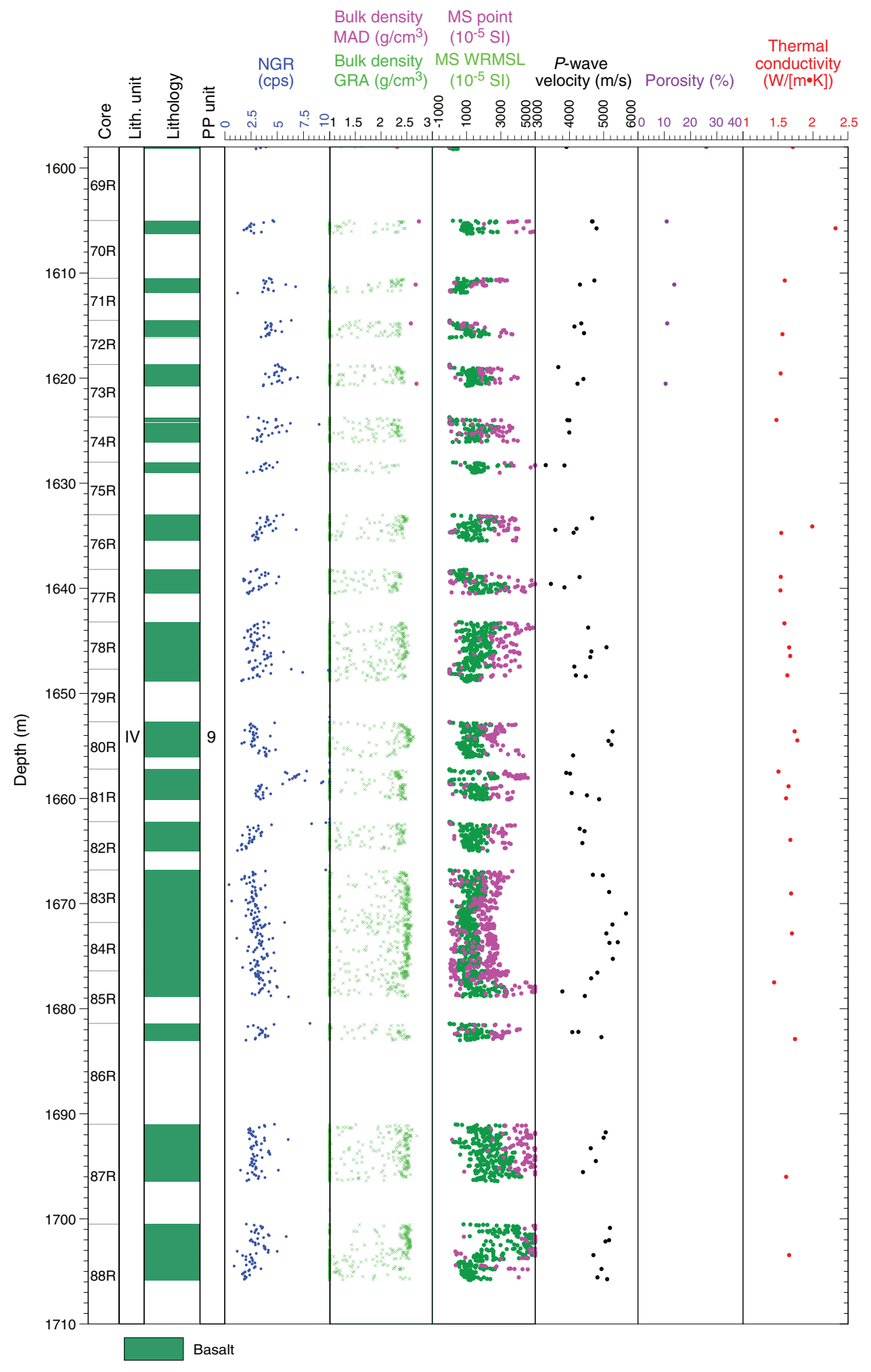


measurements, which likely explains the relatively high magnetic susceptibility in the lower part of the brownish claystone in lithostratigraphic Subunit IIA (PP Unit 7).

Lithostratigraphic Unit IV (1597.8-1710.1 m) consists mainly of basalts, which causes major changes in the physical property measurements.

\section{PP Unit 9 basalts}

Sections 368X-U1503A-69R-2 through 88R-4 recovered basalts (lithostratigraphic Unit IV). Magnetic susceptibility in the basalts is very high (Figures F27, F28) but shows some variations that might correspond to changes in the nature of the magnetized minerals or the grain size. Compared with the sedimentary rocks above the basement, $P$-wave velocity in the basalts is quite high. NGR $(<10$ counts/s) and porosity are quite low, whereas density is much higher than in the sediments. Thermal conductivity in the basalts is slightly lower than in the sediments. High magnetic susceptibility in Cores 87R and 88R ( 1691.0-1703.0 m) corresponds to basalts that display more massive textures than those from the other cores and are likely to have distinct magnetized minerals or grain size.

\section{Downhole measurements and seismic correlation}

\section{Logging operation and VSI tool}

A downhole logging string was run in Hole U1503A (Figure F29). The VSI tool string (Figure F30) was deployed to collect a vertical seismic profile (VSP) of 18 stations starting at $974.9 \mathrm{~m}$ with 50 $\mathrm{m}$ intervals to $124.9 \mathrm{~m}$. No further stations could be recorded because the pipe was set inside the casing at $71 \mathrm{~m}$. To avoid potentially deteriorated conditions in the open hole, the VSI tool string did not pass into the open hole, and all check shots were conducted inside the casing.

Rig-up for the downhole logging run with the VSI tool string started at $\sim 0400 \mathrm{~h}$ on 6 December 2018 . The tool string was deployed at $\sim 0715 \mathrm{~h}$ and reached the bottom of casing $(991.5 \mathrm{~m})$ at $\sim 0750 \mathrm{~h}$. A protected species watch was started at $0630 \mathrm{~h}$, and after $1 \mathrm{~h}$ of observation a soft ramp-up of the seismic source was performed to a maximum pressure of 2000 psi. No protected species were observed. The seismic source was deployed by the aft port crane at a distance of $\sim 48 \mathrm{~m}$ from the moonpool and $\sim 5 \mathrm{~m}$ below the sea surface (Figure F31). The seismic source was a cluster of two generator-injector (GI) guns, each with a volume of $250 \mathrm{inch}^{3}$. An MP-24 hydrophone was deployed at $7 \mathrm{~m}$ below the sea surface. The sea condition was calm.

The VSI tool string was combined with telemetry and gamma ray tools (Figure F30). A downhole recording length of $6000 \mathrm{~ms}$ with a sampling rate of $1.0 \mathrm{~ms}$ was used. A total of 104 seismic source shots were made during the experiment, from which 63 downhole seismic traces were used and processed to identify waveforms and first arrivals. A continuous gamma ray log was recorded from the bottom of the hole up past the seafloor. That log is the sole depth reference for the expedition and was planned and recorded in real time so that the uppermost gamma ray activity would correspond with the driller's seafloor depth, thus tying the station measurements to the coring data as closely as possible under the circumstances. VSI data collection concluded at $1055 \mathrm{~h}$, and the tools were returned to the surface. See Operations for further details.

\section{Interval velocity}

One-way seismic traveltimes were recorded up the hole at 18 VSI stations from 949.9 to 124.9 m (Table T13; Figure F32). Processing, including first arrival picking and stacking, was performed by Schlumberger during Expedition 368X. After the expedition, logging specialists at the Lamont-Doherty Earth Observatory provided corrected traveltimes in SEGY format (Table T13).

Based on the recorded traveltimes at the 18 stations, we calculated the interval velocity $\left(V_{\text {int }}\right)$ of individual sediment layers at $0-$ $974.9 \mathrm{~m}$ (Table T13). Calculated interval velocity is between 1706.5 and $2487.6 \mathrm{~m} / \mathrm{s}$ and in general increases with depth (Figure F33). For comparison, the average $P$-wave velocity of discrete core measurements is $2598.7 \mathrm{~m} / \mathrm{s}$ for a sediment depth of $995.1-1597.8 \mathrm{~m}$.

\section{Correlation to seismic data}

The combined VSI and $P$-wave measurements were used to calculate the velocity-depth relationship for Hole U1503A (Figure F33). The velocity-depth relationship consists of two parts: (1) for

Figure F29. Logging operation summary, Hole U1503A.

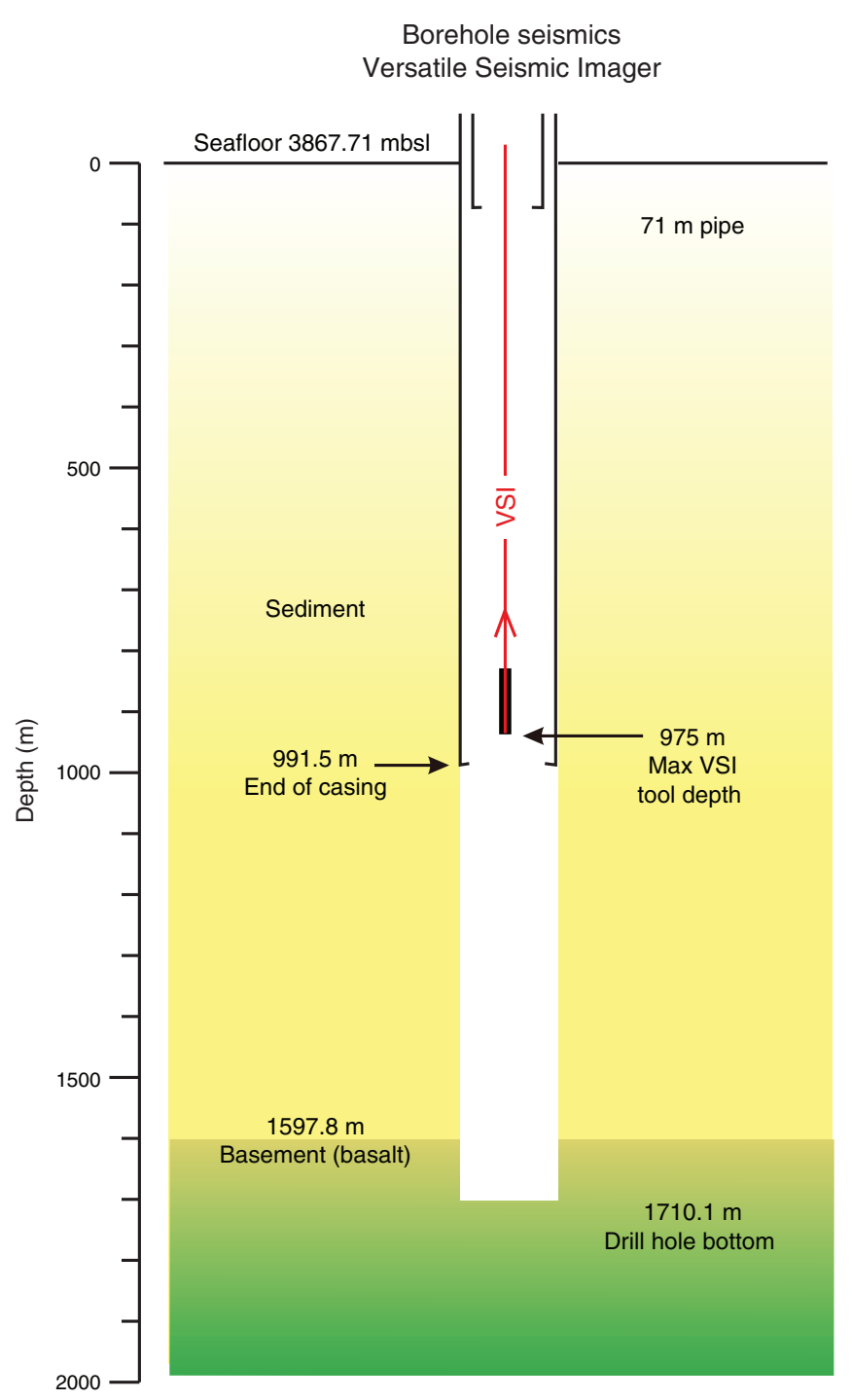


Figure F30. VSI tool string, Hole U1503A. EDTC = Enhanced Digital Telemetry Cartridge.

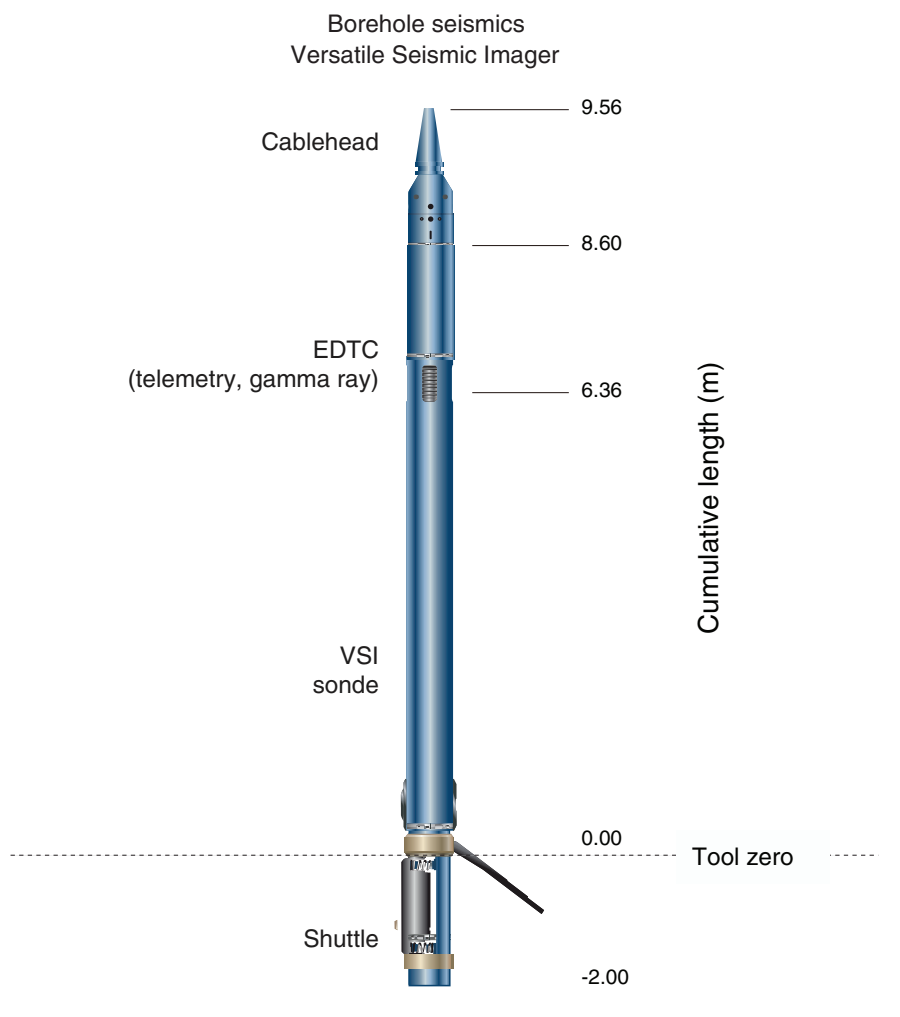

Figure F31. Seismic source deployment scheme used during the VSI logging run, Hole U1503A.

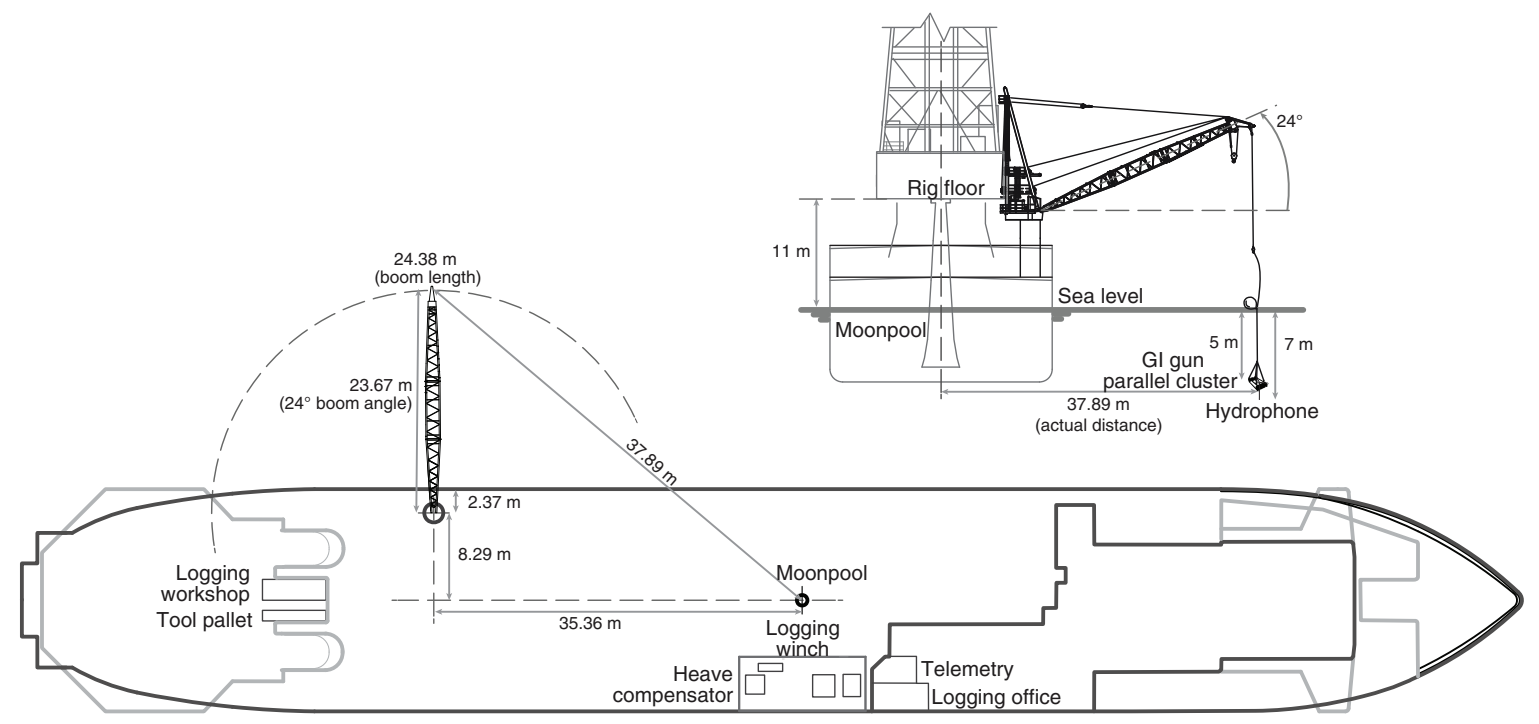

0-974.9 m, we used the interval velocity from the VSI experiment (red solid line in Figure F33), and (2) for 995.1-1710.1 m, the average $P$-wave velocity of sediment cores were used (red dotted line).

A seismic image near Hole U1503A (without depth correction) is shown in Figure F33. Seismic wave forms in Hole U1503A were extracted from this seismic data set and converted to depth using the composite depth-velocity relationship of Hole U1503A. The most prominent seismic reflectors are shown in the seismic wave forms (circles) and are connected to the same reflectors in the seismic image. 
Table T13. Vertical Seismic Imager check shot track summary, Hole U1503A. Download table in CSV format.

\begin{tabular}{ccc}
\hline $\begin{array}{c}\text { Depth } \\
(\mathrm{m})\end{array}$ & $\begin{array}{c}\text { One-way } \\
\text { traveltime } \\
(\mathrm{s})\end{array}$ & $\begin{array}{c}\text { Two-way } \\
\text { traveltime } \\
\text { after correction } \\
(\mathrm{s})\end{array}$ \\
\hline 124.9 & 2.6551 & 4.8049 \\
174.9 & 2.685 & 5.1003 \\
224.9 & 2.7121 & 5.26 \\
274.9 & 2.7398 & 5.3705 \\
324.9 & 2.7594 & 5.4425 \\
374.9 & 2.7908 & 5.5257 \\
424.9 & 2.8201 & 5.5983 \\
474.9 & 2.8436 & 5.6552 \\
524.9 & 2.8661 & 5.7074 \\
574.9 & 2.8902 & 5.7611 \\
624.9 & 2.9125 & 5.8099 \\
674.9 & 2.9344 & 5.857 \\
724.9 & 2.956 & 5.903 \\
774.9 & 2.9763 & 5.9457 \\
824.9 & 2.9966 & 5.988 \\
874.9 & 3.0198 & 6.036 \\
924.9 & 3.0399 & 6.0774 \\
974.9 & 3.0603 & 6.1194 \\
& &
\end{tabular}

Figure F32. Waveforms and first arrivals of 18 check shot stations, Hole U1503A. First arrivals were picked using Schlumberger software.

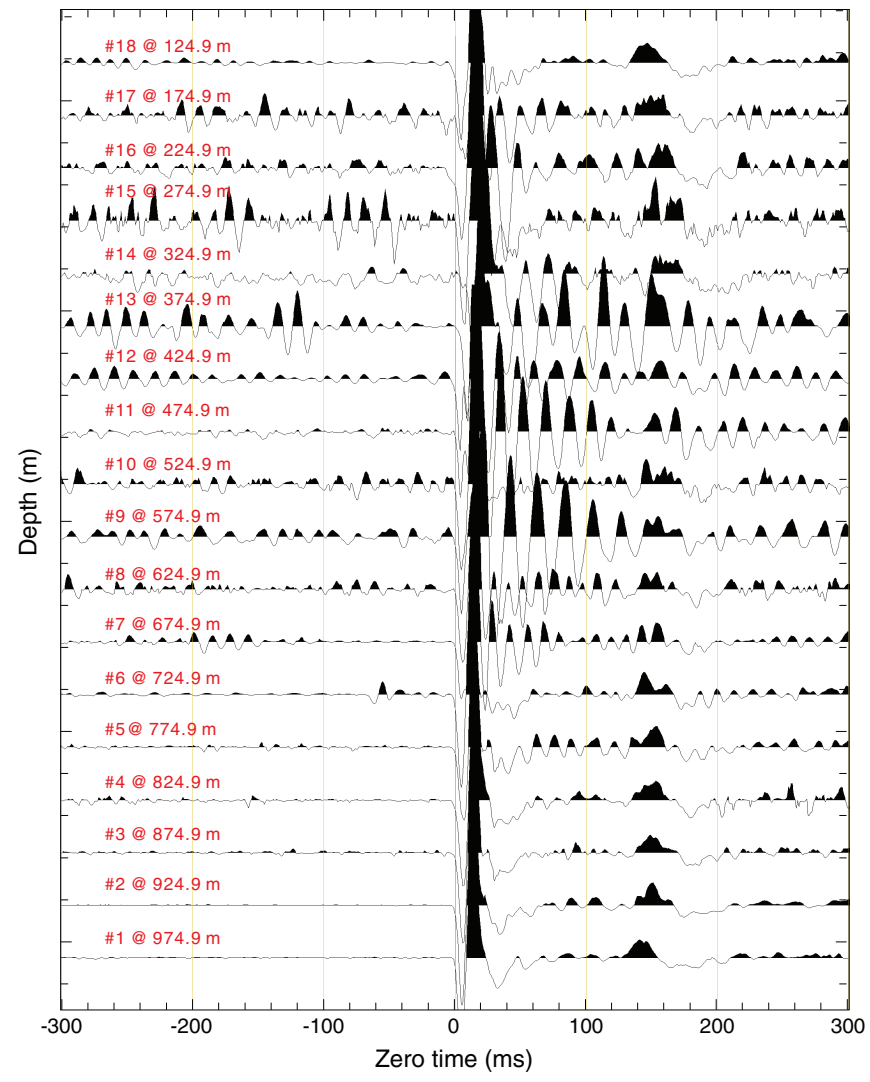


Figure F33. Physical properties, interval velocity calculated from VSI data (solid red line), average velocity for sediments (dashed red line), seismic wave forms with depth calculated using a composite velocity-depth relationship from the VSI and $P$-wave velocity, and uncorrected seismic image, Hole U1503A. Open circles and thin black lines connect prominent seismic reflectors to the individual seismic wave forms. Seismic data are from Line 04ec1555-08ec1555 (courtesy of $\mathrm{CNOOC}$ ).

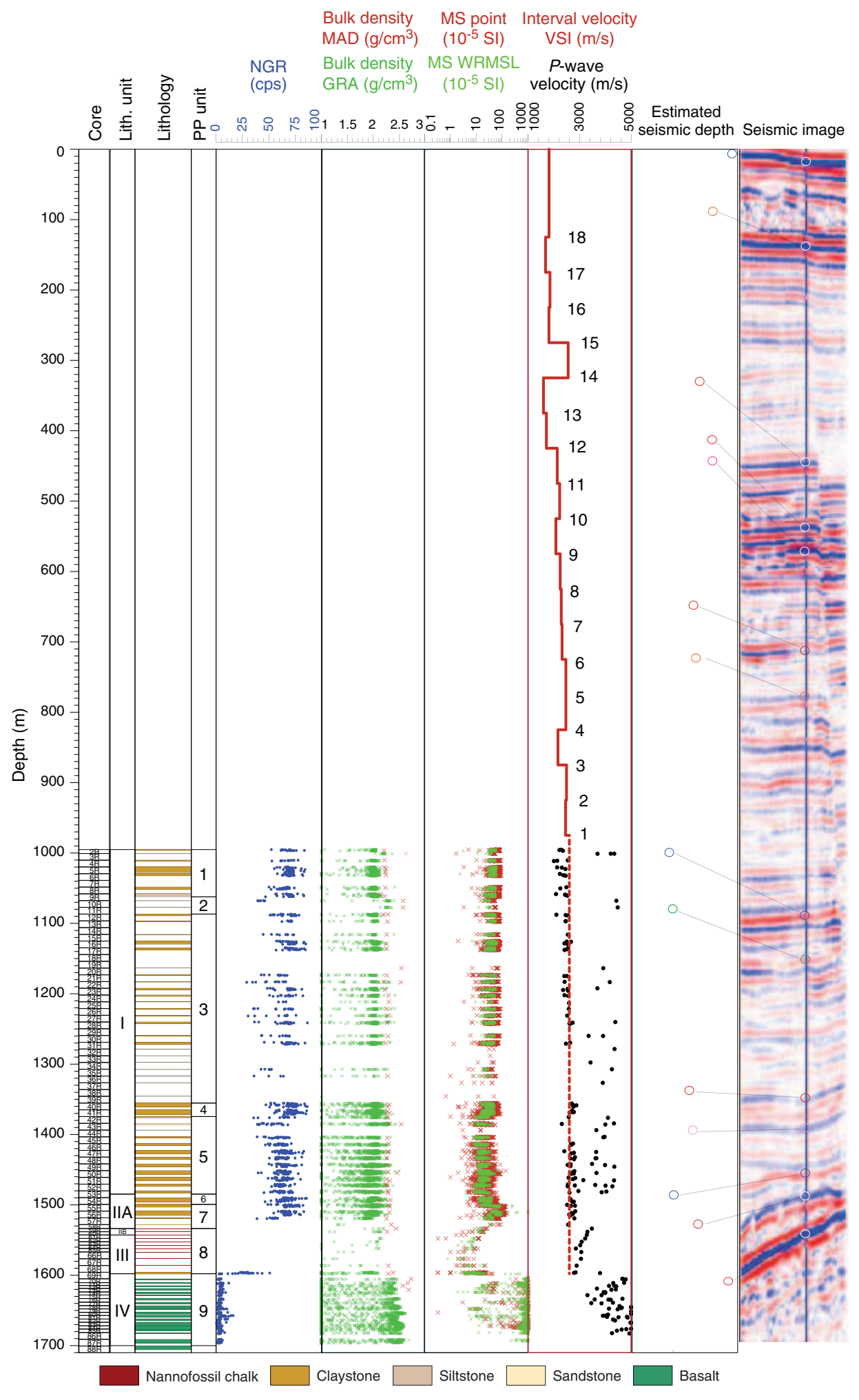




\section{References}

Briais, A., Patriat, P., and Tapponnier, P., 1993. Updated interpretation of magnetic anomalies and seafloor spreading stages in the South China Sea: implications for the Tertiary tectonics of Southeast Asia. Journal of Geophysical Research: Solid Earth, 98(B4):6299-6328. https://doi.org/10.1029/92JB02280

Childress, L.B., Alvarez Zarikian, C.A., Briais, A., Dadd, K.A., Deng, J.-M., Höfig, T.W., Huang, X.-L., Li, B., Lin, J., Liu, C., Liu, Z., Nirrengarten, M.F.R., Peate, D.W., Qiu, N., Satolli, S., Stock, J.M., Sun, Z., van der Zwan, F.M., Xiang, R., Yi, L., and Zhong, L., 2020. Expedition 368X methods supplement. In Sun, Z., Jian, Z., Stock, J.M., Larsen, H.C., Klaus, A., Alvarez Zarikian, C.A., and the Expedition 367/368 Scientists, South China Sea Rifted Margin. Proceedings of the International Ocean Discovery Program, 367/368: College Station, TX (International Ocean Discovery Program). https://doi.org/10.14379/iodp.proc.368X.102.2020

Clark, D.A., and Emerson, D.W., 1991. Notes on rock magnetization characteristics in applied geophysical studies. Exploration Geophysics, 22(3):547-555. https://doi.org/10.1071/EG991547

Horng, C.-S., Torii, M., Shea, K.-S., and Kao, S.-J., 1998. Inconsistent magnetic polarities between greigite- and pyrrhotite/magnetite-bearing marine sediments from the Tsailiao-chi section, southwestern Taiwan. Earth and Planetary Science Letters, 164(3-4):467-481. https://doi.org/10.1016/S0012-821X(98)00239-8

Larsen, H.C., Jian, Z., Alvarez Zarikian, C.A., Sun, Z., Stock, J.M., Klaus, A., Boaga, J., Bowden, S.A., Briais, A., Chen, Y., Cukur, D., Dadd, K.A., Ding, W., Dorais, M.J., Ferré, E.C., Ferreira, F., Furusawa, A., Gewecke, A.J., Hinojosa, J.L., Höfig, T.W., Hsiung, K.-H., Huang, B., Huang, E., Huang, X.-L., Jiang, S., Jin, H., Johnson, B.G., Kurzawski, R.M., Lei, C., Li, B., Li, L., Li, Y., Lin, J., Liu, C., Liu, C., Liu, Z., Luna, A., Lupi, C., McCarthy, A.J., Mohn, G., Ningthoujam, L.S., Nirrengarten, M., Osono, N., Peate, D.W., Persaud, P., Qiu, N., Robinson, C.M., Satolli, S., Sauermilch, I., Schindlbeck, J.C., Skinner, S.M., Straub, S.M., Zu, X., Tian, L., van der Zwan, F.M., Wan, S., Wu, H., Xiang, R., Yadav, R., Yi, L., Zhang, C., Zhang, J., Zhang, Y., Zhao, N., Zhong, G., and Zhong, L., 2018a. Site U1502. In Sun, Z., Jian, Z., Stock, J.M., Larsen, H.C., Klaus, A., Alvarez Zarikian, C.A., and the Expedition 367/368 Scientists, South China Sea Rifted Margin. Proceedings of the International Ocean Discovery Program, 367/368: College Station, TX (International Ocean Discovery Program). https://doi.org/10.14379/iodp.proc.367368.106.2018

Larsen, H.C., Jian, Z., Alvarez Zarikian, C.A., Sun, Z., Stock, J.M., Klaus, A., Boaga, J., Bowden, S.A., Briais, A., Chen, Y., Cukur, D., Dadd, K.A., Ding, W., Dorais, M.J., Ferré, E.C., Ferreira, F., Furusawa, A., Gewecke, A.J., Hinojosa, J.L., Höfig, T.W., Hsiung, K.-H., Huang, B., Huang, E., Huang, X.-L., Jiang, S., Jin, H., Johnson, B.G., Kurzawski, R.M., Lei, C., Li, B., Li, L., Li, Y., Lin, J., Liu, C., Liu, C., Liu, Z., Luna, A., Lupi, C., McCarthy, A.J., Mohn, G., Ningthoujam, L.S., Nirrengarten, M., Osono, N., Peate, D.W., Persaud, P., Qiu, N., Robinson, C.M., Satolli, S., Sauermilch, I., Schindlbeck, J.C., Skinner, S.M., Straub, S.M., Su, X., Tian, L., van der Zwan, F.M., Wan, S., Wu, H., Xiang, R., Yadav, R., Yi, L., Zhang, C., Zhang, J., Zhang, Y., Zhao, N., Zhong, G., and Zhong, L., 2018b. Site U1503. In Sun, Z., Jian, Z., Stock, J.M., Larsen, H.C., Klaus, A., Alvarez Zarikian, C.A., and the Expedition 367/368 Scientists, South China Sea Rifted Margin. Proceedings of the International Ocean Discovery Program, 367/368: College Station, TX (International Ocean Discovery Program). https://doi.org/ 10.14379/iodp.proc.367368.107.2018

Lurcock, P.C., and Wilson, G.S., 2012. PuffinPlot: a versatile, user-friendly program for paleomagnetic analysis. Geochemistry, Geophysics, Geosystems, 13(6):Q06Z45. https://doi.org/10.1029/2012GC004098

Martini, E., 1971. Standard Tertiary and Quaternary calcareous nannoplankton zonation. In Farinacci, A. (Ed.), Proceedings of the Second Planktonic Conference, Roma 1970: Rome (Edizioni Tecnoscienza), 2:739-785.
Müller, A., and Mathesius, U., 1999. The palaeoenvironments of coastal lagoons in the southern Baltic Sea, I. The application of sedimentary $\mathrm{C}_{\mathrm{org}} / \mathrm{N}$ ratios as source indicators of organic matter. Palaeogeography, Palaeoclimatology, Palaeoecology, 145(1-3):1-16. https://doi.org/10.1016/S0031-0182(98)00094-7

Ogg, J.G., Ogg, G., and Gradstein, F.M., 2016. A Concise Geologic Time Scale 2016: Boston (Elsevier).

Roberts, A.P., Chang, L., Rowan, C.J., Horng, C.-S., and Florindo, F., 2011. Magnetic properties of sedimentary greigite $\left(\mathrm{Fe}_{3} \mathrm{~S}_{4}\right)$ : an update. Reviews of Geophysics, 49(1):RG1002. https://doi.org/10.1029/2010RG000336

Seton, M., Whittaker, J.M., Wessel, P., Müller, R.D., DeMets, C., Merkouriev, S., Cande, S., Gaina, C., Eagles, G., Granot, R., Stock, J., Wright, N., and Williams, S.E., 2014. Community infrastructure and repository for marine magnetic identifications. Geochemistry, Geophysics, Geosystems, 15(4):1629-1641. https://doi.org/10.1002/2013GC005176

Stock, J.M., Sun, Z., Klaus, A., Larsen, H.C., Jian, Z., Alvarez Zarikian, C.A., Boaga, J., Bowden, S.A., Briais, A., Chen, Y., Cukur, D., Dadd, K.A., Ding, W., Dorais, M.J., Ferré, E.C., Ferreira, F., Furusawa, A., Gewecke, A.J., Hinojosa, J.L., Höfig, T.W., Hsiung, K.-H., Huang, B., Huang, E., Huang, X.-L., Jiang, S., Jin, H., Johnson, B.G., Kurzawski, R.M., Lei, C., Li, B., Li, L., Li, Y., Lin, J., Liu, C., Liu, C., Liu, Z., Luna, A., Lupi, C., McCarthy, A.J., Mohn, G., Ningthoujam, L.S., Nirrengarten, M., Osono, N., Peate, D.W., Persaud, P., Qiu, N., Robinson, C.M., Satolli, S., Sauermilch, I., Schindlbeck, J.C., Skinner, S.M., Straub, S.M., Zu, X., Tian, L., van der Zwan, F.M., Wan, S., Wu, H., Xiang, R., Yadav, R., Yi, L., Zhang, C., Zhang, J., Zhang, Y., Zhao, N., Zhong, G., and Zhong, L., 2018. Site U1500. In Sun, Z., Jian, Z., Stock, J.M., Larsen, H.C., Klaus, A., Alvarez Zarikian, C.A., and the Expedition 367/368 Scientists, South China Sea Rifted Margin. Proceedings of the International Ocean Discovery Program, 367/368: College Station, TX (International Ocean Discovery Program). https://doi.org/10.14379/iodp.proc.367368.104.2018

Sun, Z., Jian, Z., Stock, J.M., Larsen, H.C., Klaus, A., Alvarez Zarikian, C.A., Boaga, J., Bowden, S.A., Briais, A., Chen, Y., Cukur, D., Dadd, K.A., Ding, W., Dorais, M.J., Ferré, E.C., Ferreira, F., Furusawa, A., Gewecke, A.J., Hinojosa, J.L., Höfig, T.W., Hsiung, K.-H., Huang, B., Huang, E., Huang, X.-L., Jiang, S., Jin, H., Johnson, B.G., Kurzawski, R.M., Lei, C., Li, B., Li, L., Li, Y., Lin, J., Liu, C., Liu, C., Liu, Z., Luna, A., Lupi, C., McCarthy, A.J., Mohn, G., Ningthoujam, L.S., Nirrengarten, M., Osono, N., Peate, D.W., Persaud, P., Qiu, N., Robinson, C.M., Satolli, S., Sauermilch, I., Schindlbeck, J.C., Skinner, S.M., Straub, S.M., Zu, X., Tian, L., van der Zwan, F.M., Wan, S., Wu, H., Xiang, R., Yadav, R., Yi, L., Zhang, C., Zhang, J., Zhang, Y., Zhao, N., Zhong, G., and Zhong, L., 2018a. Expedition 367/368 methods. In Sun, Z., Jian, Z., Stock, J.M., Larsen, H.C., Klaus, A., Alvarez Zarikian, C.A., and the Expedition 367/368 Scientists, South China Sea Rifted Margin. Proceedings of the International Ocean Discovery Program, 367/368: College Station, TX (International Ocean Discovery Program). https://doi.org/10.14379/iodp.proc.367368.102.2018

Sun, Z., Jian, Z., Stock, J.M., Larsen, H.C., Klaus, A., Alvarez Zarikian, C.A., and the Expedition 367/368 Scientists, 2018b. Supplementary material, https://doi.org/10.14379/iodp.proc.367368supp.2018. Supplement to Sun, Z., Jian, Z., Stock, J.M., Larsen, H.C., Klaus, A., Alvarez Zarikian, C.A., and the Expedition 367/368 Scientists, South China Sea Rifted Margin. Proceedings of the International Ocean Discovery Program, 367/368: College Station, TX (International Ocean Discovery Program). https://doi.org/10.14379/iodp.proc.367368.2018

Yan, P., Zhou, D., and Liu, Z., 2001. A crustal structure profile across the northern continental margin of the South China Sea. Tectonophysics, 338(1):1-21. https://doi.org/10.1016/S0040-1951(01)00062-2

Zijderveld, J.D.A., 1967. AC demagnetization of rocks: analysis of results. In Collinson, D.W., Creer, K.M., and Runcorn, S.K. (Eds.), Developments in Solid Earth Geophysics (Volume 3): Methods in Palaeomagnetism: Amsterdam (Elsevier), 254-286. https://doi.org/10.1016/B978-1-4832-2894-5.50049-5 